\title{
Ecology and Development in an Island Population of Wellington Tree Weta (Hemideina crassidens).
}

A thesis presented in fulfillment of the requirements for the degree of

Master of Science in Ecology and Biodiversity

At Victoria University of Wellington. New Zealand.

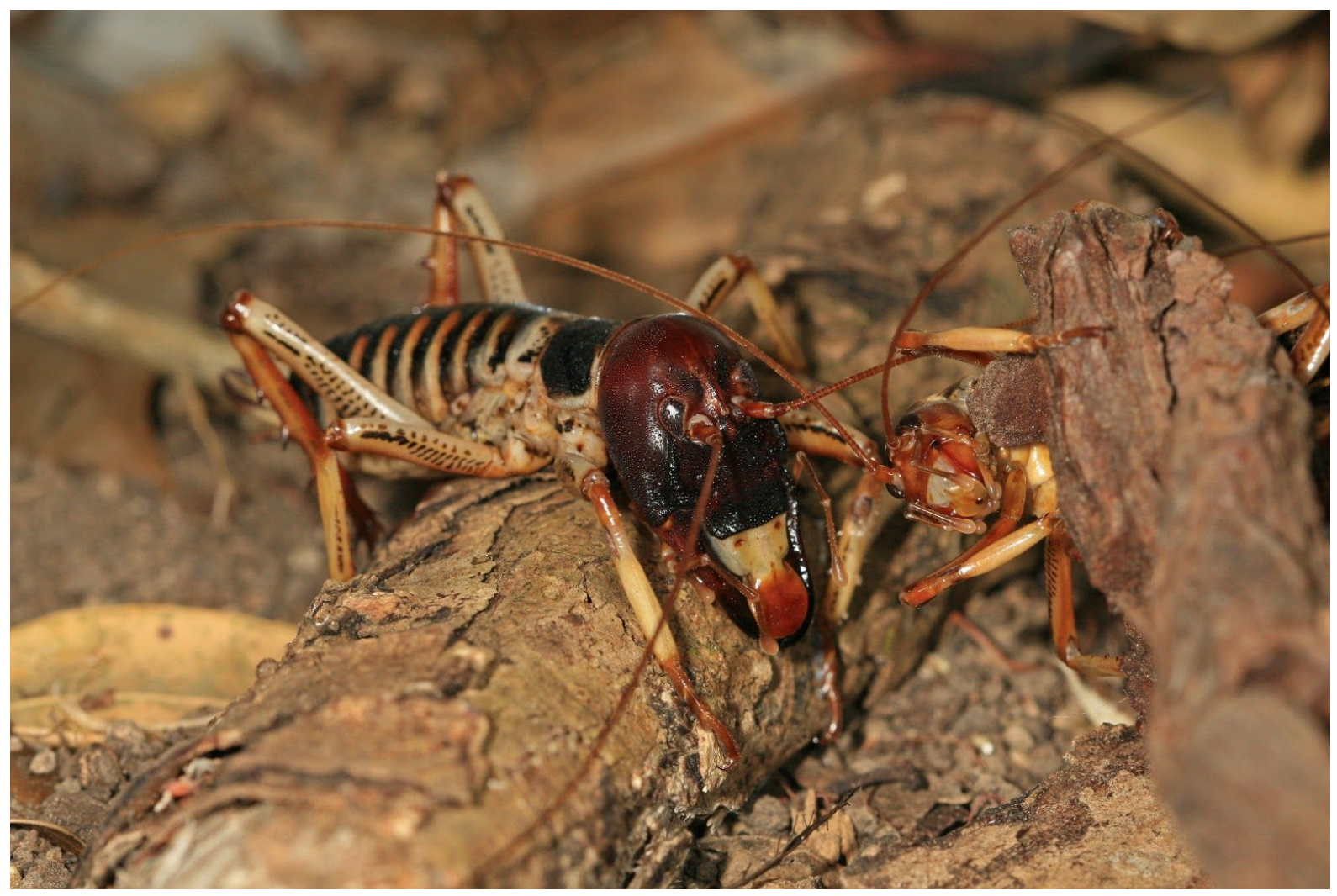

Alexander Scott Dixson

2020 


\section{Acknowledgements}

I am extremely grateful to Dr. George Gibbs for allowing me access to the wealth of data he collected during field work on Matiu/Somes Island and by rearing tree weta at his home. I would also like to thank Dr. Gibbs for many fascinating discussions about tree weta and for his feedback. Many thanks to my supervisor, Dr. Phil Lester for his ongoing encouragement, support and guidance. A big thank you to Dr. Shirley Pledger for advice and support with data analysis and for many interesting conversations about Science. 


\begin{abstract}
Sexual selection and the mating system of the Wellington tree weta has been extensively studied during the last 15 years. In the past 10 years, nutritional ecology and factors affecting the distribution of species in the genus Hemideina have also been examined in great detail. This recent work and the extensive studies of New Zealand tree weta species that preceded it provide much context and comparison for this thesis, which examines the ecology of a population of tree weta living on Matiu/Somes Island. Less is known about factors affecting the development of the exaggerated male weaponry that is characteristic of much of the genus Hemideina. This thesis firstly presents a mark-recapture study conducted over 42 months on Matiu/Somes Island to obtain ecological information about the population. Secondly, this thesis presents an experiment on the effects of protein supplement on growth and weaponry in male Wellington tree weta derived from the Matiu/Somes Island population. The results of the field study indicate that male tree weta live longer than females on Matiu/Somes Island and weapon size is positively related to adult longevity of males. Seasonal patterns shown in the population on Matiu/Somes Island and inferences about aspects of their life cycle are discussed. Female tree weta on Matiu/Somes Island formed harems throughout each year and there was a positive relationship between males weapon size and the number of females in a harem. Results do not indicate seasonal differences in harem-forming behaviours of females. The results of the captive rearing study include a shorter development time and larger weaponry as adults in males raised on a protein supplemented diet, compared to individuals raised on an entirely herbivorous diet. Details of differences in the course of development are also discussed for the two diet treatment groups.
\end{abstract}


Table of contents

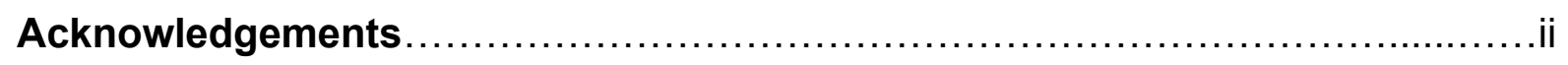

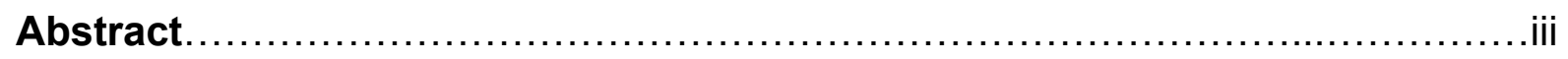

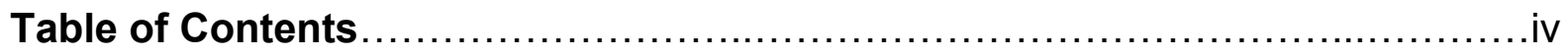

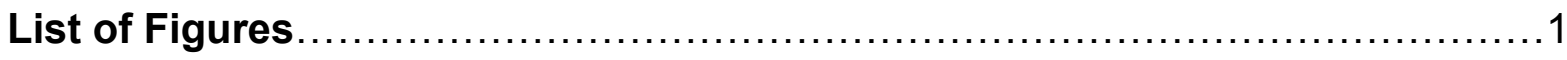

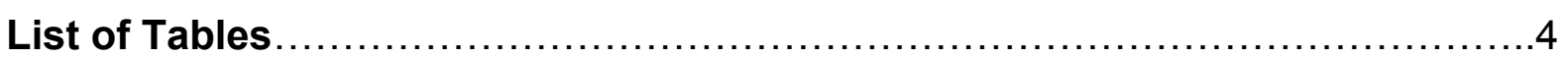

Chapter One: Introduction to the Wellington Tree Weta and Study Sites in this

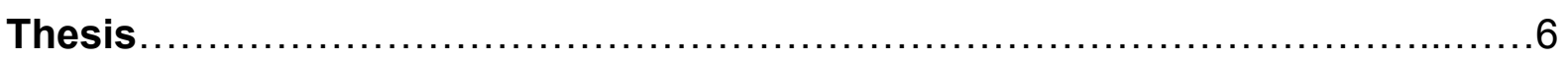

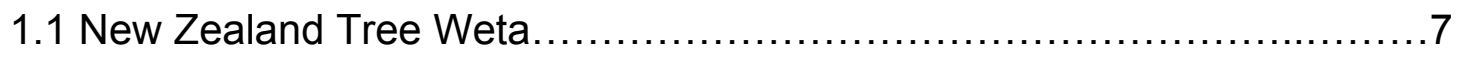

1.2. Sexual dimorphism, male weaponry and mating system in Wellington tree

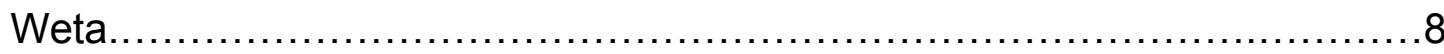

1.3. Development in Tree Weta...................................................11

1.4 Thesis outline: Aims and Purpose of this Study...........................13

Chapter Two: Survivorship and Seasonal patterns in Wellington Tree Weta on

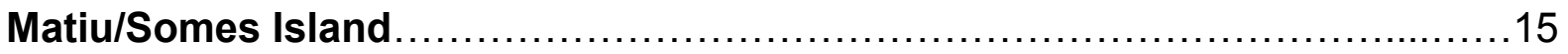

2.1 Introduction.................................................................

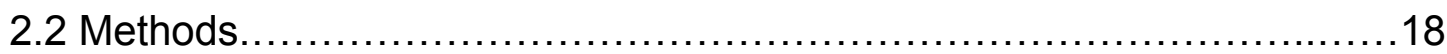

2.2.1 Field site and artificial galleries.............................. 18

2.2.2 Statistical methods for mark recapture study ....................22

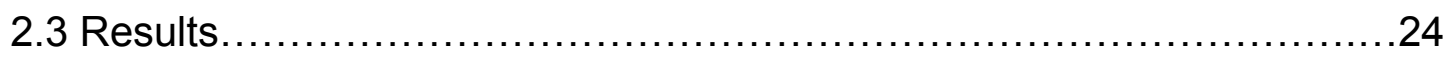

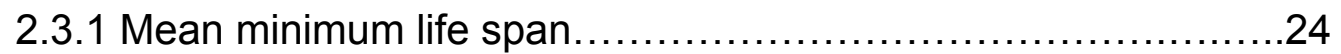

2.3.2 Adult male and female survival and recapture estimates.........27

2.2.3 Male weapon size and survival estimates..........................29

2.3.4 Seasonal patterns on Matiu/Somes Island.........................32

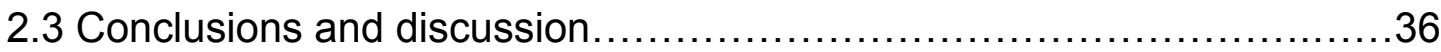

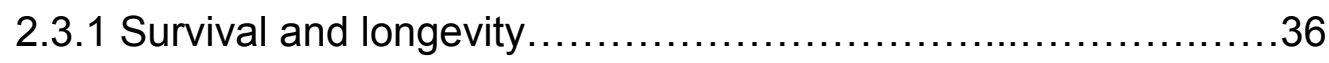


Chapter Three: Use of artificial galleries by females and selection for exaggerated male weaponry in Wellington tree weta on Matiu/Somes Island.

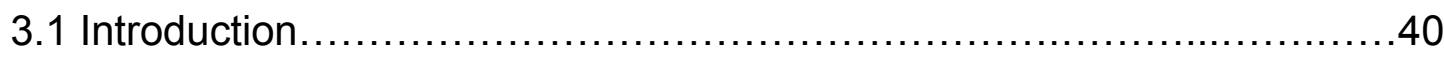

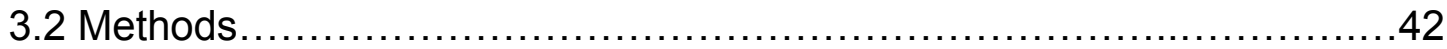

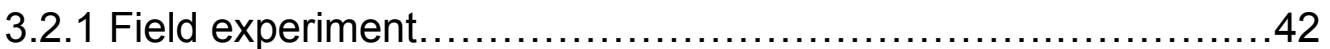

3.2.2 Statistical methods for calculating distribution of females in

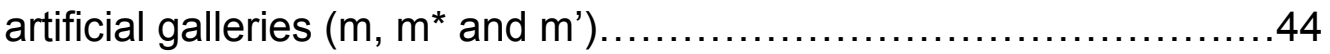

3.2.3 Statistical methods for calculating the strength of sexual selection on male weaponry .................................................. 45

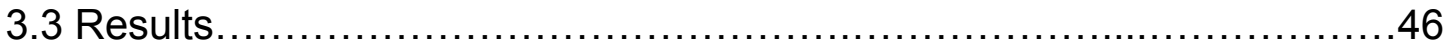

3.3.1 Distribution of females in artificial galleries: mean density of females and female mean crowding $\left(\mathrm{m}, \mathrm{m}^{*}\right.$ and $\left.\mathrm{m}^{\prime}\right)$....................46

3.3.2 Gallery use and male weaponry and body size....................48

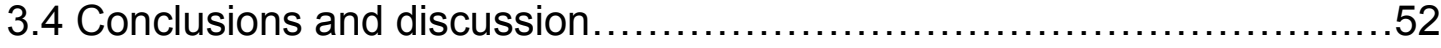

3.4.1 Gallery use by females..........................................

3.4.2 Male weapon size and gallery occupation........................53

Chapter Four: Diet has a major effect on growth rate and adult weapon size in

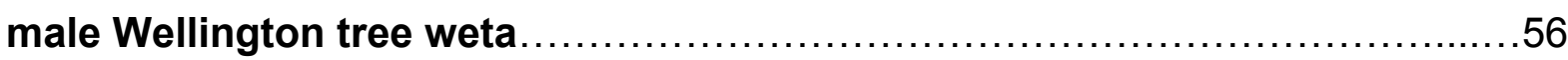

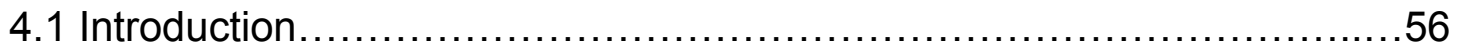

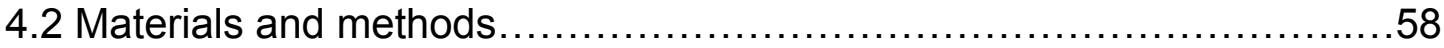

4.2.1 Test subjects and rearing conditions ............................58

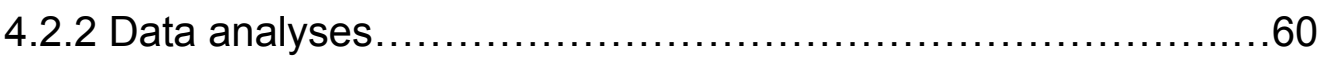

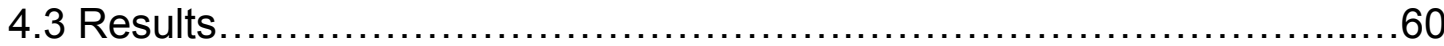

4.3.1 Development time from hatching to adult in high vs low protein

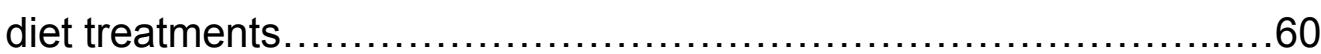

4.3.2 Juvenile allometry 1: 128-145 days from hatching.................61

4.3.3 Juvenile allometry 2: 219-236 days from hatching................63 
4.3.4 Adult allometry: 250-410 days from hatching (protein treatment group) or 363-446 days from hatching (herbivory treatment group)...65

4.3.5 Growth curves and growth rate..............................68

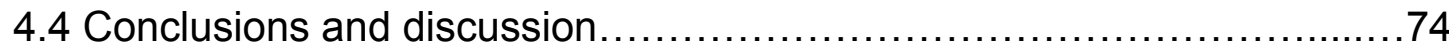

4.4.1 Protein supplemented diet was linked to reduced development time and larger adult weapon size................................. 74

4.4.2 Male Wellington tree weta reared on a protein supplemented diet invested more in weapon size vs body size earlier in development and

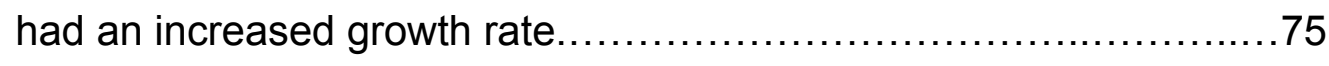

4.4.3 Males in both diet treatments reached the average Matiu/Somes Island adult female head length 219-236 days after hatching...........76

Chapter Five: Summary and future directions $\ldots \ldots \ldots \ldots \ldots \ldots \ldots \ldots \ldots \ldots \ldots \ldots$

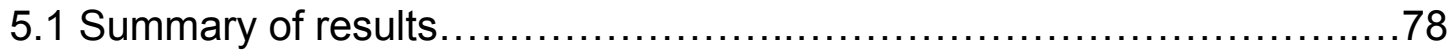

5.2 Discussion and future directions $\ldots \ldots \ldots \ldots \ldots \ldots \ldots \ldots \ldots \ldots \ldots \ldots \ldots . \ldots 1$

References .83

\section{Appendices:}

Appendix A: Statistics from major axis regression of log head length on log femur length for males (above) and females (below) from all areas surveyed on Matiu/Somes (M/S) Island and from Mana Island, years separate. Maud Island measurements from Kelly (2005a) included for comparison....

Appendix B: Seasons and mean monthly temperatures on Matiu/Somes Island, data used in thesis.

Appendix C: Guidelines for classifying male Hemideina crassidens to instar, from Spencer (1995 pp.17-18)... .96 


\section{List of Figures}

- Fig. 1.1 Distribution of the seven Hemideina spp. across the North and South Islands of New Zealand. (Accessed 20th May 2019 from: http://wetageta.massey.ac.nz/Text\%20files/treeweta.html)

- Figure 1.2: An adult male (left) and adult female (right) on Matiu/Somes Island showing pronounced sexual dimorphism. Photograph taken by A. Dixson and E. Greene.

- Figure 2.1: Above: North west coast of New Zealand showing Matiu/Somes Island and Mana Island. Below: Matiu/Somes Island A = forest patch involved in the present study. $B$ = original release site for founder populations in 1995 and 1996. The approximate distribution of artificial refuge boxes is shown on the right

- Figure 2.2 Artificial galleries used as diurnal shelters on Matiu/Somes Island. (a) shows the refuges containing two large and 8 small galleries each. (b) shows the single large gallery boxes.

- Figure 2.3 Adult male (left) and female (right) on Matiu/Somes Island marked using numbered tags attached to individual's pronotum.

- Figure 2.4: Average minimum adult lifespan, in months, of males $(n=521)$ and females $(n=331)$.

- Figure 2.5. Relative frequency of adult males and females with mean minimum lifespan (MML) ranging from 1 to 12 months.

- Figure 2.6. Average minimum life span, in months, of males maturing after eight, nine or ten nymphal instars.

- Figure 2.7 Variation in head length and body size in 521 adult males and 331 adult female Wellington tree weta over 42 months on Matiu/Somes Island. Individuals were measured once as adults when they were marked with a numbered tag. A line has not been fitted as the purpose of this graph is to show the characteristics of the population.

- Figure 2.8: Mean monthly temperature (solid line) and rainfall (dashed line) on Matiu/Somes Island. Data from NIWA New Zealand national climate 
database; Matiu/Somes Island weather recording station 1971 - 2000.

- Figure 2.9 Seasonal patterns of newly marked and recaptured adult males and females.

- Figure 2.10: Monthly counts of adult males and females. The histogram shows both newly marked and recaptured over 3 years shown with monthly average temperature shown as a line.

- Figure 2.11: sub-adults counted each month (above) and average monthly counts of nymphs (below) males and females counts over three years.

- Figure 2.12: Summary of results showing seasonal life history events for a single generation/cohort of tree weta on Matiu/Somes Island. The shaded boxes show events for a single generation.

- Figure 3.1 volumes of large (a) and small (b) and single large (c) artificial galleries.

- Figure 3.2. Partial regressions showing the relationship between harem size (females per male) and (a) male head length (weapon size), (b) male femur length (body size).

- Figure 4.1: Development time from hatching to adult in high vs low protein diet treatments. The components of the boxes are the interquartile range showing the middle $50 \%$ of development times. The whiskers show the upper and lower $25 \%$ of development times with the dots showing outliers in the herbivory treatment.

- Figure 4.2: Allometric scaling of head length vs right femur length in juveniles 128-145 days from hatching. The slopes are statistically similar $\left(X^{2}{ }_{1}=0.450\right.$, $P<0.502)$ between the two diet treatment groups and the two groups, but show a shift along a common axis.

- Figure 4.3: Allometric scaling of head length vs right femur length in juveniles 219-236 days from hatching. Although slopes are equal between the two diet treatment groups $\left(X^{2}{ }_{1}=0.018, P=0.893\right)$ there was a significant difference in elevation $\left(X^{2}{ }_{1}=15.02, P=0.0001\right)$.

- Figure 4.4: Allometric scaling of head length vs right femur length in adults 250-410 days from hatching (protein treatment group) or 363-446 days from hatching (herbivory treatment group). The slopes are equal between the two 
diet treatment groups $\left(X^{2}{ }_{1}=0.361, P=0.548\right)$ and there is a significant difference in elevation $\left(X^{2}{ }_{1}=32.96, P<0.0001\right)$.

- Figure 4.5 Growth curve showing the change in head length (above) and the change in right hind femur length (below) between hatching and adulthood.

- Figure 4.6: Growth curve showing comparison in the changing ratio of head length : femur length in the two diet treatment groups. 


\section{List of Tables}

- Table 2.1. Notation for either daily survival $(\varphi)$ or recapture (p) probability parameters in the Cormack-Jolly-Seber (CJS) models of the adult population on Matiu/Somes Island over 42 months.

- Table 2.2 Results of CJS mark-recapture analysis using the program MARK to model the effects of group (male vs. female) and time (42 monthly intervals) on survival $(\varphi)$ and recapture $(p)$ probabilities. I also modeled the effects of season and temperature on $\varphi$ and $p$.

- Table 3.1. Mean density of females $(m)$ and female mean crowding $\left(m^{*}\right)$; mean differences between gallery types. Tukey HSD tests: multiple comparisons of means, 95\% family-wise confidence level.

- Table $3.2 \mathrm{~m}, \mathrm{~m}^{*}$ and $\mathrm{m}$ ' Means and standard errors of average mean density of females $(m)$, female mean crowding in galleries occupied by a single adult male $\left(m^{*}\right)$, and galleries occupied by females with or without a male present $\left(m^{\prime}\right)$. (All results \pm 1 standard error).

- Table 3.3. Occupation of gallery resources by males and females showing occasions where multiple males and females occupied the same gallery. This table is a summary of data across all months and all gallery types.

- Table 3.4. Tukey HSD tests showing the direction of difference in mean head length and mean femur length between the three gallery treatments. All differences were significant $(P<0.0001)$.

- Table 3.5. Standardized linear $(\beta \pm S E)$ selection gradients of harem size on head size and body size in male Hemideina crassidens. Estimated in 3 experimental gallery size treatments, results pooled over three years of monthly observations.

- Table 4.1 Mean +/- SE, range and CV of head length ( $\mathrm{mm}$ ) and femur length $(\mathrm{mm})$ in male Hemideina crassidens during two points in juvenile development and as adults.

- Table 4.2 Estimates of male instar at 3 growth stages based on guidelines from Spencer (1995). Individuals are organised into groups of 10th, 9th and 
8th instar adults and by longest duration of development from hatching to maturity within each group.

- Table 4.3. Values for head length (HL) and right hind-femur length (FL) in millimeters for three island populations of Wellington tree weta: Matiu/Somes Island, Mana Island and Maud Island. 


\section{Chapter One:}

\section{Introduction and Thesis Outline.}

The life history and evolution of organisms is shaped by a struggle to survive and reproduce. The goal of life history theory is to explain why there is variation in traits such as size at birth, clutch size, growth rate, survival and mortality based on what is optimal for different species (Roff 1992). The evolution of life histories can be viewed as depending on the interaction of the external and internal factors that affect an organism throughout its life (Stearns 2000). External factors relate to how the environment and ecological factors affect survival and reproductive success at different stages of life. Internal factors often involve trade offs between different life history traits, again playing out at different stages of life. These trade offs include allocating limited resources differently to growth of specific structures during development and may become factors that affect longevity and mortality as adults (Warren et. al 2013). It is clear that the internal and external factors that shape the survival and reproduction of organisms cannot be easily separated (Hill 2011; Stearns 2000).

Field studies of a species can allow us to observe trends in a population over several generations. These patterns can yield valuable insights into how external factors in a specific environment might affect survival and reproductive success. Laboratory studies that investigate what conditions are required to cause the range of phenotypic variation within a species may provide insights into the internal factors shaping life history traits. Much of the baseline data required to understand the life history of the Wellington tree weta is not available in the literature. Questions like how long does $H$. crassidens live in the wild and what factors affect development and possible trade offs during development have only begun to be addressed in recent years. 


\subsection{New Zealand Tree Weta}

My study species is the Wellington tree weta (Hemideina crassidens), a flightless nocturnal insect that is endemic to New Zealand (Gibbs 2001). H. crassidens is classified taxonomically as follows:

Order: Orthoptera

Suborder: Ensifera

Superfamily: Stenopalmatoidea (Burmeister 1838)

Family: Anostostomatidae

Subfamily: Deinacridinae

Genus: Hemideina (Walker 1869)

Species: $H$. crassidens (Blanchard 1851).

The Wellington tree weta is one of seven tree weta species in the genus Hemideina, all are endemic to New Zealand and distributed across the North and South Islands (Trewick and Morgan-Richards 2004). Unlike its congeners, $H$. crassidens can be found on both the North and South Island although its range extends only to the lower part of the North Island and the west coast of the South Island (Fig. 1.1).

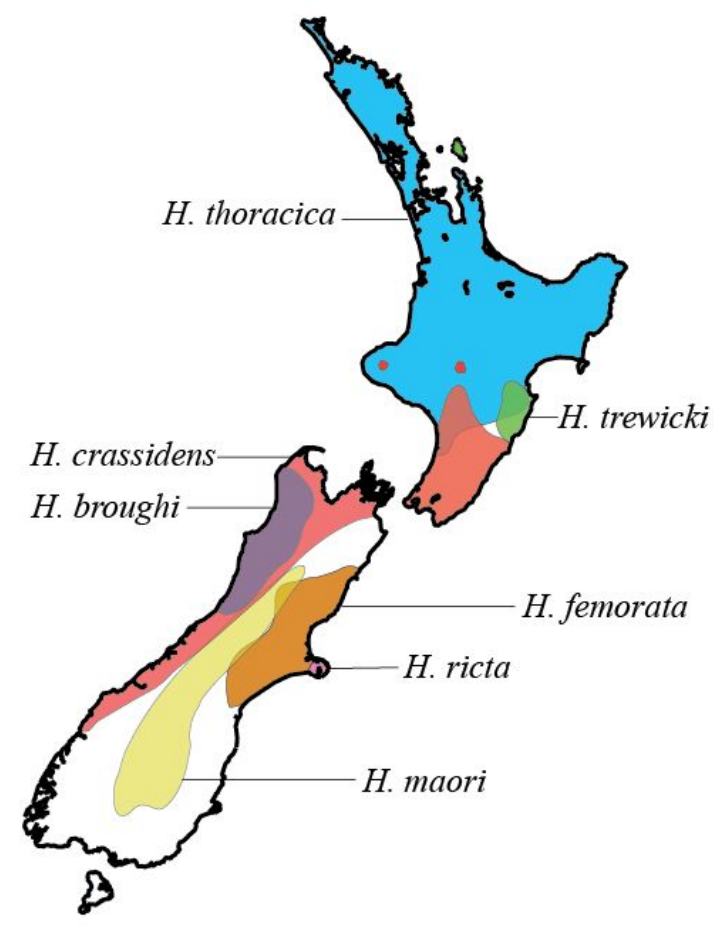

Fig. 1.1 Distribution of the seven Hemideina spp. across the North and South Islands of New Zealand.

(Accessed 20th May 2019 from: http://wetageta.massey.ac.nz/Text\%20files/treeweta.html) 


\subsection{Sexual dimorphism, male weaponry and mating system in Wellington tree weta.}

Six out of the seven recognised species in the genus Hemideina show pronounced sexual dimorphism and exaggerated male weapons in the form of increased mandible length (Field and Deans 2001). H. broughi is the only species in the genus Hemideina that lacks sexual dimorphism while the others all show some degree of exaggeration of male weapons. Studies using morphological characteristics, nuclear DNA and mtDNA by Morgan-Richards and Gibbs (2001) and Trewick and Morgan-Richards (2004) suggest that $H$. broughi is likely to be more closely related to weta in the genus Deinacrida. $H$. crassidens and $H$. maori have the most pronounced sexual dimorphism and most exaggerated male weaponry in their genus (Figure 1.2; Figure 1.3; Field and Deans 2001, Kelly 2005a).

The six sexually dimorphic species of Hemideina also share a behavioural trait where females form aggregations (Morgan-Richards and Gibbs 2001). Male and female tree weta seek shelter and safety from diurnal predators in naturally occurring cavities in trees known as 'galleries' or in the case of the alpine weta H. maori, under rocky outcroppings called 'tors' (Gwynne and Jamieson 1998; Leisnham et al. 2003). In tree weta species whose mating systems have been most studied $(H$. crassidens, $H$. maori and $H$. thoracica) aggregations of females defended by males are referred to as 'harems' (Koning and Jamieson 2001; Kelly 2006a, 2006b, 2006c, 2008a; Wehi et al. 2013a, 2017). Field experiments suggest that female harem-forming behaviour in $H$. thoracica may be season-dependent rather than persisting throughout the year (Wehi et al. 2013a).

Male-male competition may involve direct contests for mates (harem defense polygyny) or competition for resources required by mates (resource defense polygyny) (Emlen and Oring 1977, Shuster and Wade 2003). As female mates become scarcer and harder to access, the intensity of sexual selection on male traits that enhance their ability to compete for mates is predicted to become more intense 
(Emlen and Oring 1977). The distribution of female mates influences the intensity of sexual selection on males (Emlen \& Oring 1977). As a result, the habitat structure of forest patches has been shown to influence the mating behaviour and strategies of male and female Wellington tree weta (Kelly 2006b, 2006c). Male $H$. crassidens may engage in alternative reproductive strategies where males with smaller weaponry may increase their reproductive success by seeking out "sneak" matings by waiting near defended harems or wandering in search of mates (Nason 2019; Kelly 2006b; Spencer 1995). Males with larger weapons are more likely to behave as guards and mate with harems of females aggregated in galleries, or to alternate between 'sneak' and 'guard' strategies (Wilson and Kelly 2019). Recent experiments that used genetic paternity analysis found that $H$. crassidens males employing alternative reproductive strategies have similar levels of reproductive success (Nason 2019).

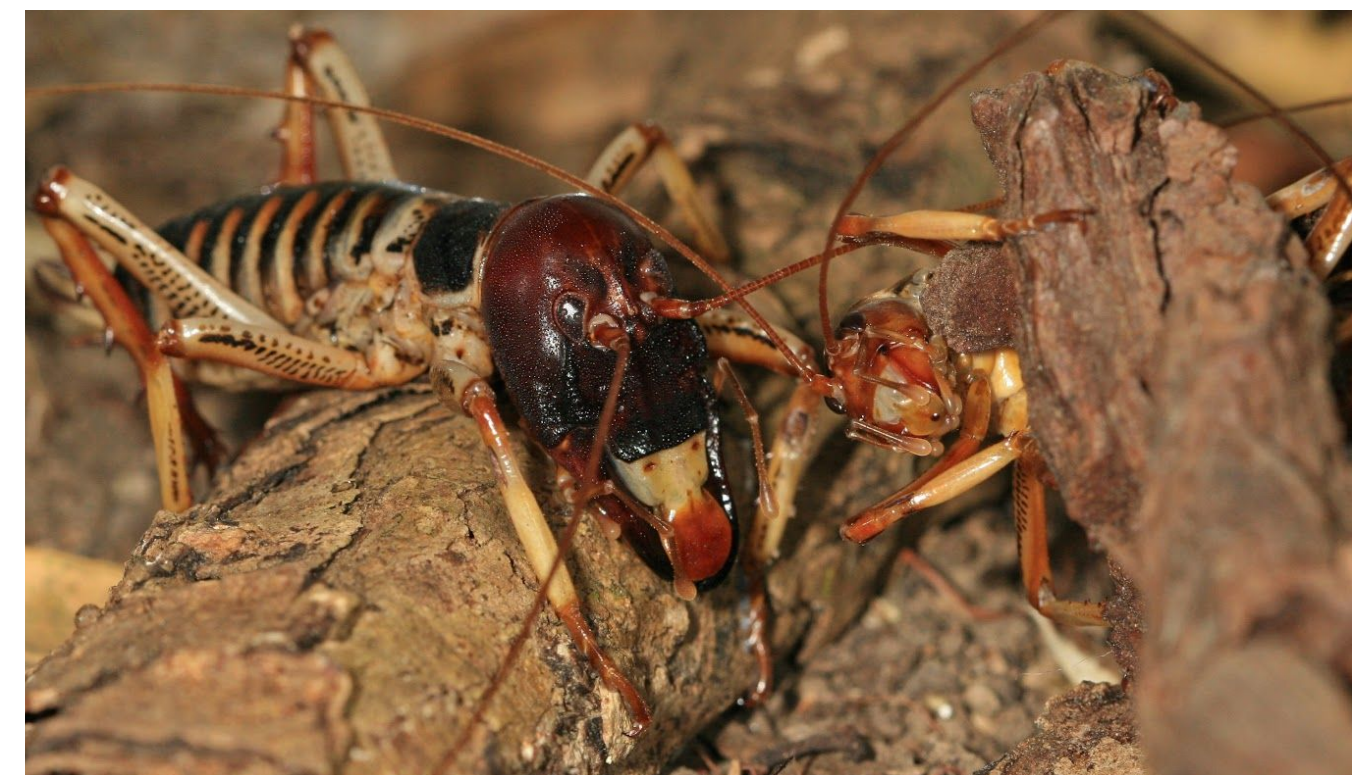

Figure 1.2: An adult male (left) and adult female (right) on Matiu/Somes Island showing pronounced sexual dimorphism. Photograph taken by A. Dixson and E. Greene.

In $H$. crassidens, male weapon size plays a significant role in determining the outcome of male competition for access to harems (Kelly 2006a) and thus influences male reproductive success (Kelly 2005a, 2006d, 2008a). Kelly (2006a) demonstrated experimentally that contests over resources among male $\mathrm{H}$. crassidens are resolved due to asymmetries in fighting ability. Asymmetry in fighting ability was quantified as 
the absolute difference in head length (weapon size) between a male defending a group of females and a rival male intruder (Kelly 2006a). Kelly (2006a) demonstrated that males with the most exaggerated weaponry benefit from reduced contest duration and less escalation of aggression when faced with a rival having smaller weaponry. Male H. maori with the largest heads have also been found living with larger harems of females than males with reduced head length (Koning and Jamieson 2001; Leisnham and Jamieson 2004). The length of female mandibles is shaped by natural selection pressures for foraging rather than sexual selection resulting from competition for mates (Kelly and Adams 2010).

Tree weta are hemimetabolous, meaning after hatching they go through a series of instars as nymphs before maturing as adults without a major reorganisation of their body. This is unlike development in holometabolous insects, which pass go through larval and pupal stages before becoming adults. Male tree weta may reach maturity after 8, 9 or 10 instars (Field and Deans 2001; Spencer 1995) and male weapon size is positively correlated with instar number (Figure 1.3). This leads to what has been described as a trimorphic distribution of head lengths in adult male $\mathrm{H}$. crassidens (Kelly and Adams 2010). All females reach maturity after 10 instars (Spencer 1995). The precise number of instars involved in male development in all Hemideina species has not been confirmed. Currently, neither the physiological mechanisms nor the genetic basis of polymorphism in male tree weta are well understood. 


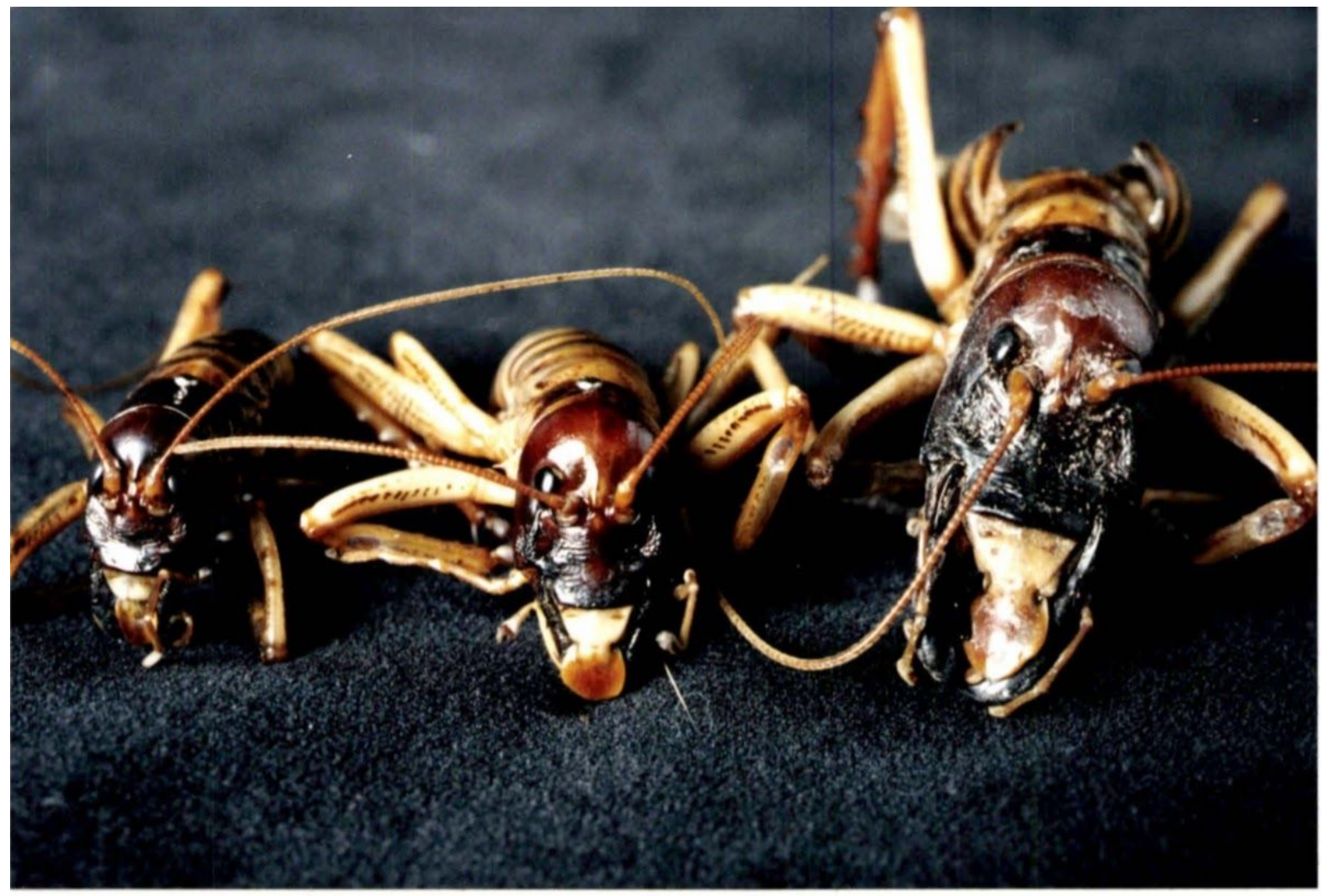

Figure. 1.3 Three morphs of adult male that matured after 8, 9 or 10 instars showing variation in adult male weapon size. (Photograph taken from Spencer 1995 page 30)

\subsection{Development in Tree Weta.}

The production of exaggerated secondary sexual traits has been shown in a range of species to depend on an individual organism's condition during development (Andersson 1986; Warren et al. 2013; Emlen 2008). Hill (2011) defined condition as "the relative capacity to maintain functionality of vital systems within the body" and as the sum of the somatic (physiological) state, the genotype, and the epigenetic state of the individual. During development an individual will be faced with environmental challenges such as food availability or challenges to the immune system and these pressures can affect the somatic (physiological) state and contribute to an organism being in relatively better or worse condition (Warren et al. 2013). In many insects the development of exaggerated sexually-selected traits such as ornaments or weapons is condition-dependent (Lavine et al. 2015; Warren et. al 2013). Examples of well-studies species where diet quality affects weapon size include the horned beetle 
Onthophagus acuminatus (Emlen 1997) and the tobacco hornworm Manduca sexta (Truman 2006). Individuals in relatively poor condition as a result of less optimal nutrition during development may be unable to allocate resources to the growth of exaggerated sexually-selected traits (Kodric-Brown et al. 2006).

Foraging strategies will affect what nutrients are consumed and this is likely to have an impact on development. Boggs (2009) summarized the importance of nutritional ecology as follows: "What organisms eat, when they eat, and how they allocate what's eaten yield observed life-history and foraging traits, whether it be the role of royal jelly in determining the reproductive fate of a female bee... or of plant quality affecting growth rate of an insect herbivore". The amounts of dietary protein, lipid, carbohydrate and nitrogen have been shown to affect development time, growth rate and adult phenotype of males in a number of orthopteran species (reviews in: Esperk 2007; Chown and Nicolson 2004). In terms of how tree weta allocate nutritional resources to different life history traits, much remains to be learned. A study by Wehi et al. (2013b) demonstrated that $H$. crassidens has the capacity to compensate by choosing specific foods and balance its intake of protein and carbohydrate but does not always do so. The researchers hypothesized that the ability to tolerate nutrient imbalance is an advantage because $H$. crassidens does not forage nightly and has evolved in environments where protein is not always available (Wehi et al. 2013b). Tree weta are selective in their choice of plant species. $H$. crassidens and $H$. thoracica show preference for leaves with high nitrogen content and may actively avoid species of plants that produce inhibitory compounds (Dewhurst 2012). Studies of $H$. thoracica (Brown 2013; Brown et al. 2018) also demonstrated that tree weta are selective when foraging and prefer plant species whose leaves contain higher concentrations of lipids. Invertebrate remains have been found in tree weta frass (Wilson and Jamieson 2005; Dewhurst 2012), possibly indicating a supplemental source of protein and nitrogen. Tree weta may also engage in cannibalism (Wehi et al. 2013b). I have observed H. crassidens on Matiu/Somes Island eating bird scat, likely to be a source of nitrogen (pers. obs.). It is clear that tree weta are best described as 'opportunistic omnivores' (Griffin et al. 2011; Dewhurst 2012) rather than herbivores. 
Temperature is a key environmental factor affecting the life cycle of insects (Beck 1983; Danks 2006; Diaz and Fereres 2005). In order to optimise the timing of events in development, many insect species show evidence of plasticity in the number of instars or duration of specific instars as adaptations to food availability or changing temperature (Esperk et al. 2007). Tree weta may go through a seasonal diapause and it is possible that tree weta eggs may require a certain period of exposure to cold temperatures in order to hatch (Danks 2006). Spencer (1995) found that $H$. crassidens eggs would not hatch when reared at constant temperature indoor indicating that eclosion was not triggered without a drop in temperature. Studies involving $H$. ricta have supported the hypothesis that exposure to a full winter is required for eggs to hatch (van Heugten 2015). Following hatching, temperature influences growth rate and instar length in many orthopterans (Whitman 2008; Esperk et al. 2007). Experiments using $H$. crassidens and $H$. thoracica collected from high and low altitude populations revealed that temperature and collection location had a dramatic effect on growth rate (Minnards 2011; Minnards et al. 2014). Tolerance and responses to temperature have also been important factors to consider in modelling the shifting ranges of tree weta species (Trewick and Morgan-Richards, 1995, Minnards 2011, Bulgarella et al., 2014).

\subsection{Thesis outline: Aims and Purpose of this Study}

I was very fortunate to have been given access to an unpublished long-term data set collected by Dr. G.W. Gibbs on Matiu/Somes Island. Dr. Gibbs shared the raw data sheets with me and I collated and analysed the data. I was also fortunate to have been able to spend time working on Matiu/Somes Island to add to this data and become familiar with the island's environment. Dr. Gibbs also gave me access to data from an unpublished experiment on the effects of diet on growth rate and development in male Wellington tree weta. The animals used as subjects in this experiment came from the Matiu/Somes Island population at the time of the field experiment and mark recapture study. Taken together, data from the field and lab experiments provides an excellent opportunity to test predictions about life history 
traits, behaviour related to mating system and development in an island population of the Wellington tree weta. The purpose of this study is to contribute to a growing body of knowledge about the ecology and development of the Wellington tree weta. My thesis is split up into three parts as follows:

Chapter Two: Survivorship and Seasonal patterns in Wellington Tree Weta on Matiu/Somes Island.

I present an analysis of a mark-recapture study carried out over 42 months on Matiu/Somes Island. I discuss seasonal patterns in the population of $H$. crassidens using the long-term data and present estimates of survival and longevity in adult males and females.

Chapter Three: Use of artificial galleries by females and selection for exaggerated male weaponry in Wellington tree weta on Matiu/Somes Island.

I present a statistical examination of female mean crowding and harem formation in artificial gallery refuges on Matiu/Somes Island. I also investigate patterns of gallery occupation by males and discuss evidence for sexual selection on male weaponry in H. crassidens.

Chapter Four: Diet has a major effect on growth rate and adult weapon size in the Wellington tree weta, Hemideina crassidens.

I present the results of an experiment that used captive-reared weta from the Matiu/Somes Island population. Subjects were raised from hatching to adulthood on either a protein supplemented or an herbivory-only diet. I discuss correlations between the two diet treatments and variation in head length, body size and development time. 
Chapter Two:

Survivorship and Seasonal patterns in Wellington Tree Weta on Matiu/Somes Island.

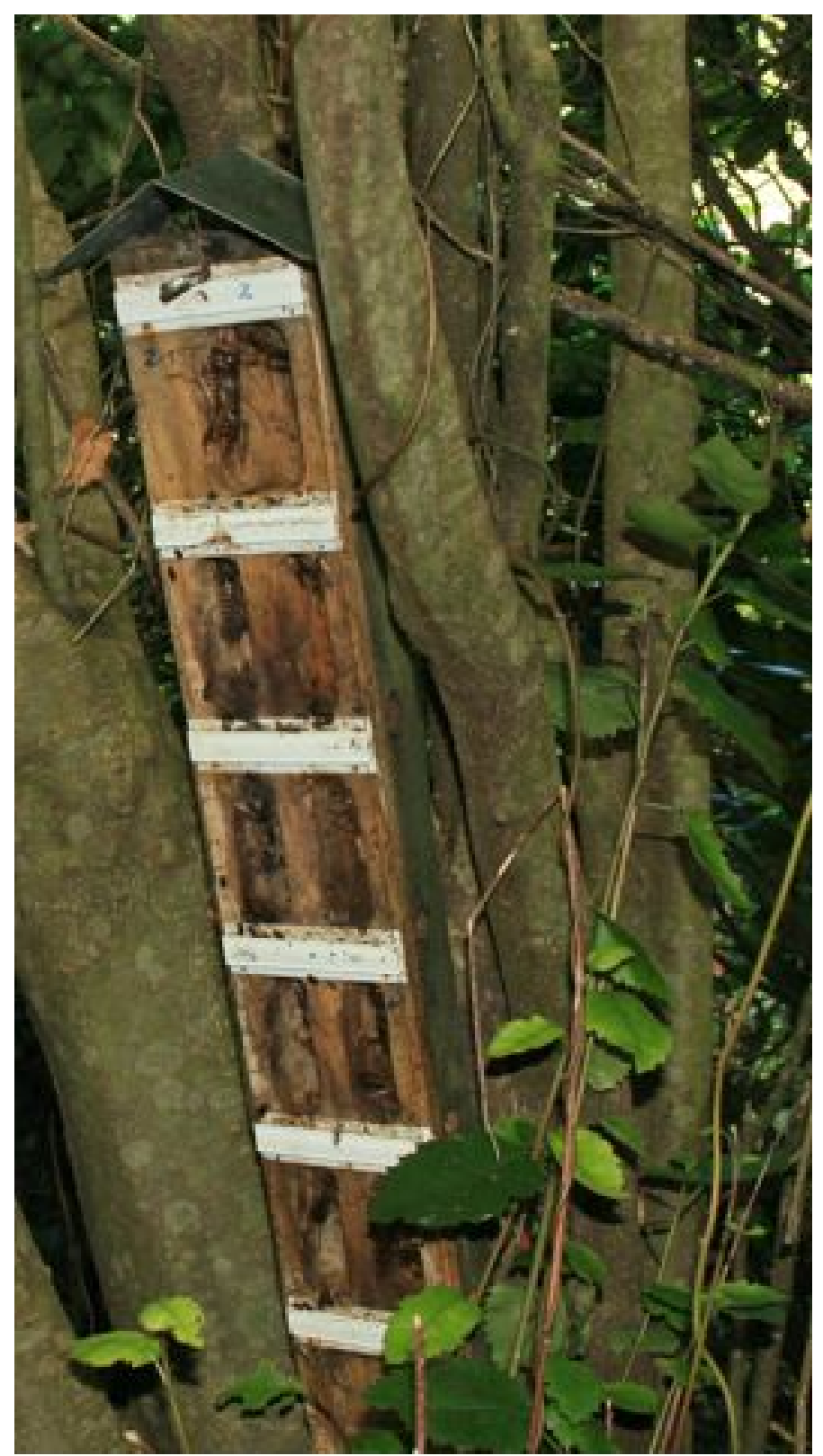




\subsection{Introduction.}

The life cycle of insects involves variation in traits such as growth rates, the age and size at which sexual maturity is reached, number of offspring, mortality and longevity (Stearns, 2000; Braendle, Heyland, and Flatt 2011). As in other taxa, tree weta may maximize their survival and reproductive success, which are key components of fitness, by exploiting environmental information to control patterns of development and behaviour (Danks, 2007; Beck 1983). Many studies on insects have revealed plasticity in both development time and number of juvenile instars in response to environmental influences (Egset et al. 2011). Examples include the effects of season length at different altitudes on the grasshopper Omocestus viridulus (Berner and Blankenthorn 2006), temperature on the lettuce aphid, Nasonovia ribisnigri (Diaz and Ferares 2005), photoperiod/day length on the cricket, Modicogryllus siamensis (Taniguchi and Tomioka 2003) and diet on the tobacco hornworm Manduca sexta (Kingsolver 2007). By examining population trends alongside seasonal cycles of changing temperature and rainfall it is possible to suggest inferences about the influence of these abiotic factors on life history and development (Danks, 2007; Bradshaw et al. 2007).

Wellington tree weta, Hemideina crassidens (Orthoptera: Tettigonioidea: Anostostomatidae), are endemic to New Zealand, which has a complex and varied climate. The distribution of $H$. crassidens tree weta in the North and South Islands (Figure 1.1) reflects this species' tolerance of lower temperatures, in contrast to less cold tolerant species like H. thoracica (Trewick and Morgan-Richards 1995; Bulgarella et al. 2014). Tree weta are ectothermic, therefore seasonal temperature changes and the length of growth season may represent critical environmental factors potentially affecting growth rate, timing of adulthood and longevity. Development rate in $H$. crassidens has been shown to be influenced by adaptations to variation in length of growth season at different altitudes and temperature (Minards 2011; Minnards et al. 2014) and also by diet (Griffin 2011 and see Chapter 4). 
By following individually marked and measured animals over time we can use mark and recapture analysis to model factors affecting survival (Lebreton et al. 1992). Demographic data on a population also allows us to observe life history trends and then make inferences about phenology, or the timing of events in the life cycle of an organism. Mark and recapture studies of alpine weta (Hemideina maori) have provided a useful precedent to interpreting information on life cycle and population dynamics using mark and recapture (Jamieson et al. 2000; Leisnham et al. 2002, 2003). Previous mark recapture studies of $H$. crassidens have focussed on 2-3 months of each year with the aim of examining movement patterns and use of refuge sites (Kelly 2006c) but such data cannot be used to show seasonal patterns as tree weta may live two to three years (Leisnham et al. 2003; Wehi et al. 2013a) and experience significant seasonal variation in environmental conditions throughout the year.

Aims:

A major objective of this chapter is to report baseline life history data of $H$. crassidens on Matiu/Somes Island. The 42 consecutive monthly observations made during this field study provide an unprecedented opportunity to examine life history and population dynamics in an island population of $H$. crassidens.

- The first aim of this study is to examine the survival and longevity of adult male and female $H$. crassidens in the wild using analysis of a long term mark and recapture study used. I compare estimates of adult lifespan survival and recapture rates between males and females and within 8th, 9th and 10th instar adult males showing variation in weapon size.

- The second aim of this study is to investigate seasonal patterns in the life cycle of Wellington tree weta on Matiu/Somes Island. Given that juvenile development and adult lifespan may each be more than a year in $H$. crassidens, I will examine seasonal trends shown by the overlapping generations. 


\subsection{Methods.}

\subsubsection{Field site and artificial galleries:}

Wellington tree weta (Hemideina crassidens) were studied on Matiu/Somes Island, New Zealand ( $\left.41^{\circ} 15^{\prime} \mathrm{S}, 174^{\circ} 51^{\prime} \mathrm{E}\right)$. Matiu/Somes Island is a $24.9 \mathrm{Ha}$ scientific reserve composed of patches of regenerating forest. Matiu/Somes Island has been free of mammalian predators (e.g. rodents) since 1989 and was deforested for use as a quarantine station for livestock until facilities were closed in 1995 and the island became a scientific reserve. Extensive re-planting of native forest providing suitable habitat for tree weta has taken place during the last 30 years since the island was taken over by the Department of Conservation. Replanting efforts resulted in coastal forest comprised of Dysoxylum spectabile (kohekohe), Beilschmiedia tawa (tawa), Corynocarpus laevigatus (karaka) and Hedycarya arborea (pigeonwood) and coastal scrub including Melicytus crassifolius (mahoe), Phormium cookianum (flax), Ozothamnus leptophyllus (tauhinu), Coprosma propinqua (mingimingi) and Coprosma repens (taupata) (Chronis 2009). Founder populations of $\mathrm{H}$. crassidens were translocated from Mana Island $\left(41^{\circ} 05^{\prime} \mathrm{S}, 174^{\circ} 46^{\prime} \mathrm{E}\right)$ to Matiu/Somes Island in April 1996 (14 males, 19 females) and again in August 1997 (7 males, 19 females) (Watts et al. 2008). To the best of my knowledge all Wellington tree weta living on Matiu/Somes Island to present day are descended from these two founder population totaling 62 individuals translocated from Mana Island in 1996 and 1997 (Watts et al. 2008). The present study was conducted on the east side of Matiu/Somes Island, in the forest patch immediately adjacent to the original release site (Figure 2.1), between June 2000 and December 2003. I use mark and recapture data collected at monthly intervals over three years and six months by G.W. Gibbs on Matiu/Somes Island to examine life history and the mating system of the Wellington tree weta. This data has not previously been analysed and is part of a larger dataset on the morphology and distribution of $H$. crassidens on Matiu/Somes Island collected by G.W. Gibbs and myself discussed throughout this thesis. 

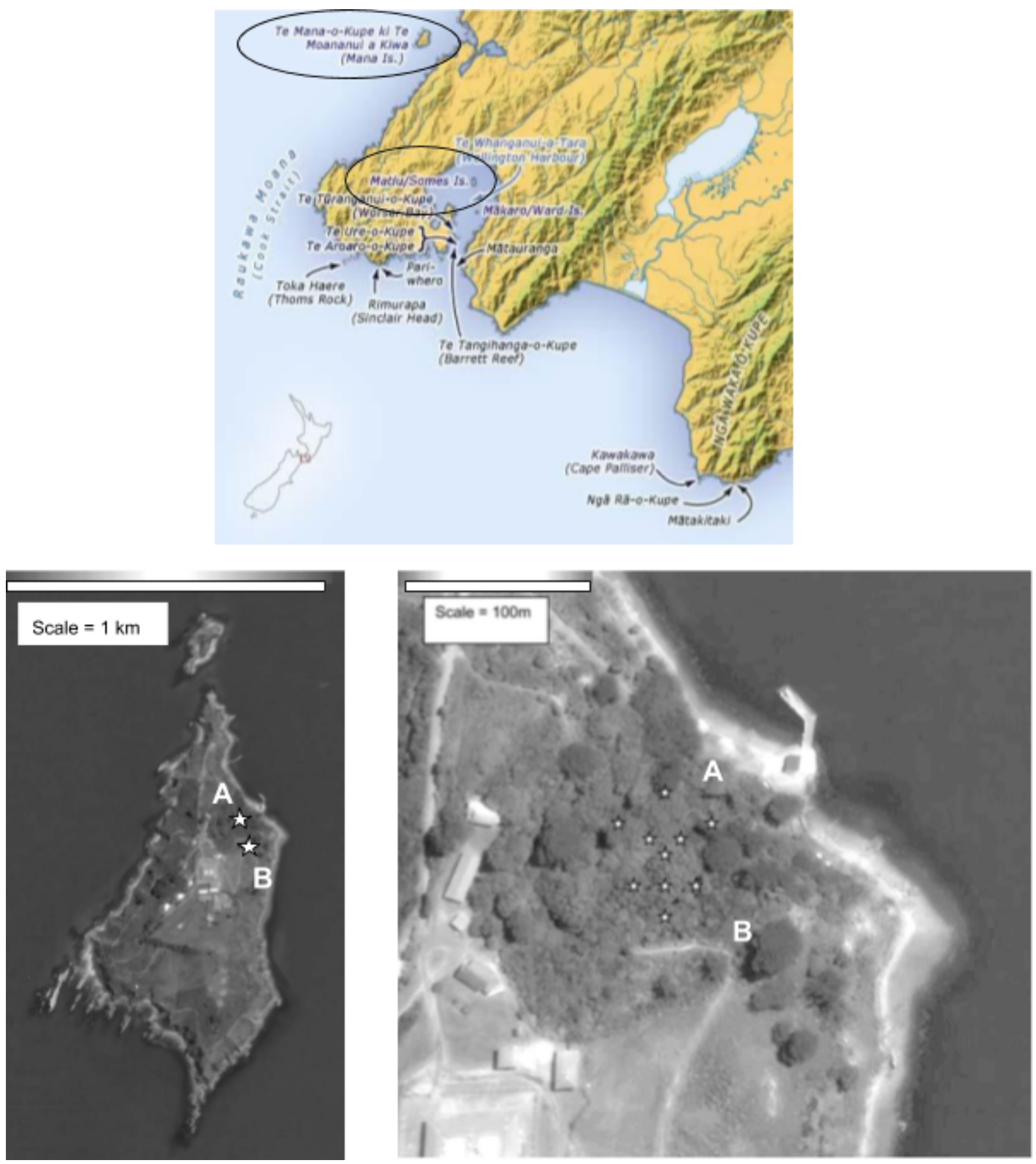

Figure 2.1:

Above: North west coast of New Zealand showing Matiu/Somes Island and Mana Island. (from https://teara.govt.nz/en/map/14150/kupes-place-names)

Below: Matiu/Somes Island $A=$ forest patch involved in the present study. $B=$ original release site for founder populations in 1995 and 1996. The approximate distribution of artificial refuge boxes is shown on the right. (from https://www.google.com/earth/ circa 2009). 
Ten numbered boxes (Figure 2.2) were installed based on those designed by Trewick \& Morgan-Richards (2000). Each contained one medium-sized $(80 \mathrm{~mm} x$ $50 \mathrm{~mm} \times 25 \mathrm{~mm})$ gallery and ten small $(80 \mathrm{~mm} \times 25 \mathrm{~mm} \times 25 \mathrm{~mm})$ numbered galleries (Figure 2.2a). A further ten large galleries $(105 \mathrm{~mm} \times 65 \mathrm{~mm} \times 25 \mathrm{~mm}$ ) similar in design to those used by Bowie et al. (2013) were contained in ten separate single boxes (Figure 2.2b). The diameter of the entrance holes on all boxes was $25 \mathrm{~mm}$. Both types of artificial refuge shown in figure 2.2 were located in the same forest patch (Figure 2.1). All one hundred small galleries and ten large galleries, plus a further ten separate large galleries, were surveyed for occupation each month. Thus, a total of 120 artificial galleries were surveyed each month for 42 consecutive months. After December 2003 some of the artificial galleries were moved to other parts of Matiu/Somes Island and data was collected at two monthly intervals (see appendix A). I note that as this study design effectively only involves a single study site with no replication, my ability to extrapolate results more broadly is therefore limited.

The artificial galleries used in this study allowed for minimal disturbance of the occupants over 42 months of observations. It is impossible to sample natural galleries without destroying them as they must be split open to extract tree weta. The number of naturally occuring galleries in the forest on Matiu/Somes Island was probably smaller and more limited compared to older forests (Kelly 2008a). As a result, it is likely that the artificial galleries were a valuable resource to the tree weta and were therefore frequently used and reused by individuals. The total area of Matiu/Somes Island is approximately 24.9 ha (62 acres) and forests occur in patches so the small area likely also increased the probability of recapturing weta and improved estimates of their longevity. 

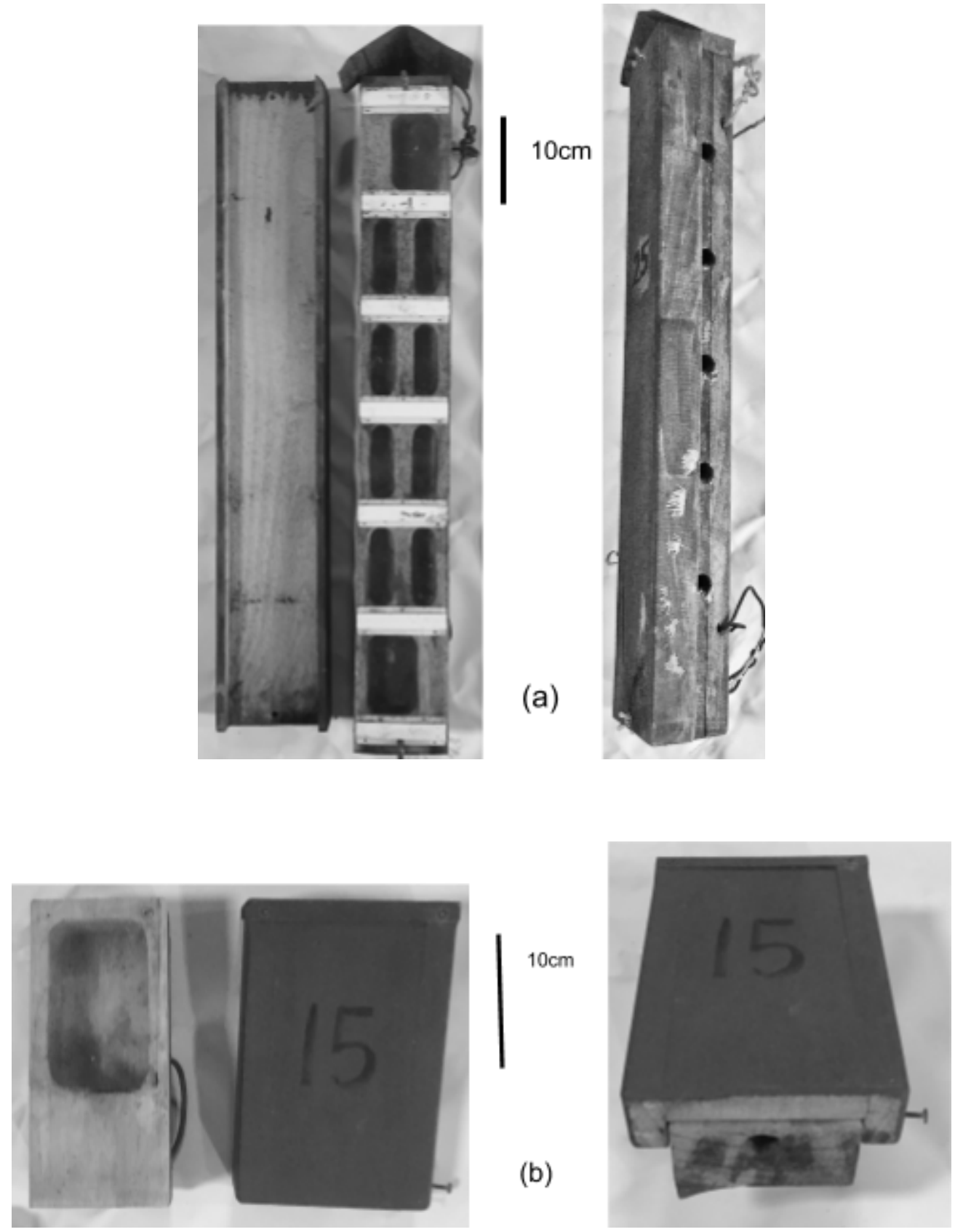

Figure 2.2 Artificial galleries used as diurnal shelters on Matiu/Somes Island. (a) shows the refuges containing two large and 8 small galleries each. (b) shows the single large gallery boxes. (Photographs by A.S. Dixson).

\section{Animal collection and measurement:}

Adult male and female Wellington tree weta were uniquely marked (Figure 2.3) by first lightly abrading the waxy cuticle in the center of the pronotum with an emery 
board then attaching a tag with a small drop of superglue [10 second drying Selleys Supa Glue, (Selleys Chemical Co. Pty. Ltd.)]. Tags were paper (numbered 001-999) covered with clear waterproof epoxy glue (Jamieson 2000). Morphological measurements of head size and body size (right hind femur length) were made with Vernier dial callipers to the nearest $0.1 \mathrm{~mm}$. Marking and measuring of each adult tree weta took 2-3 minutes, after which it was released into the same artificial gallery in which it was found. Adulthood and sex were determined by examining the cerci of male weta which are straight during juvenile development and curved and flexible in adulthood (Stringer and Cary 2001). The female ovipositor is straight during juvenile stadia and composed of three valves of equal length, in adulthood the ovipositor is curved and the two lateral valves are longer than the central valve (Stringer and Cary 2001; Moller 1985). Information about the appearance of early stage nymphs and sub-adult males and females was also recorded during the mark-recapture study. All measurements analysed in this chapter were made at monthly intervals by G.W. Gibbs between June 2000 and December 2003.
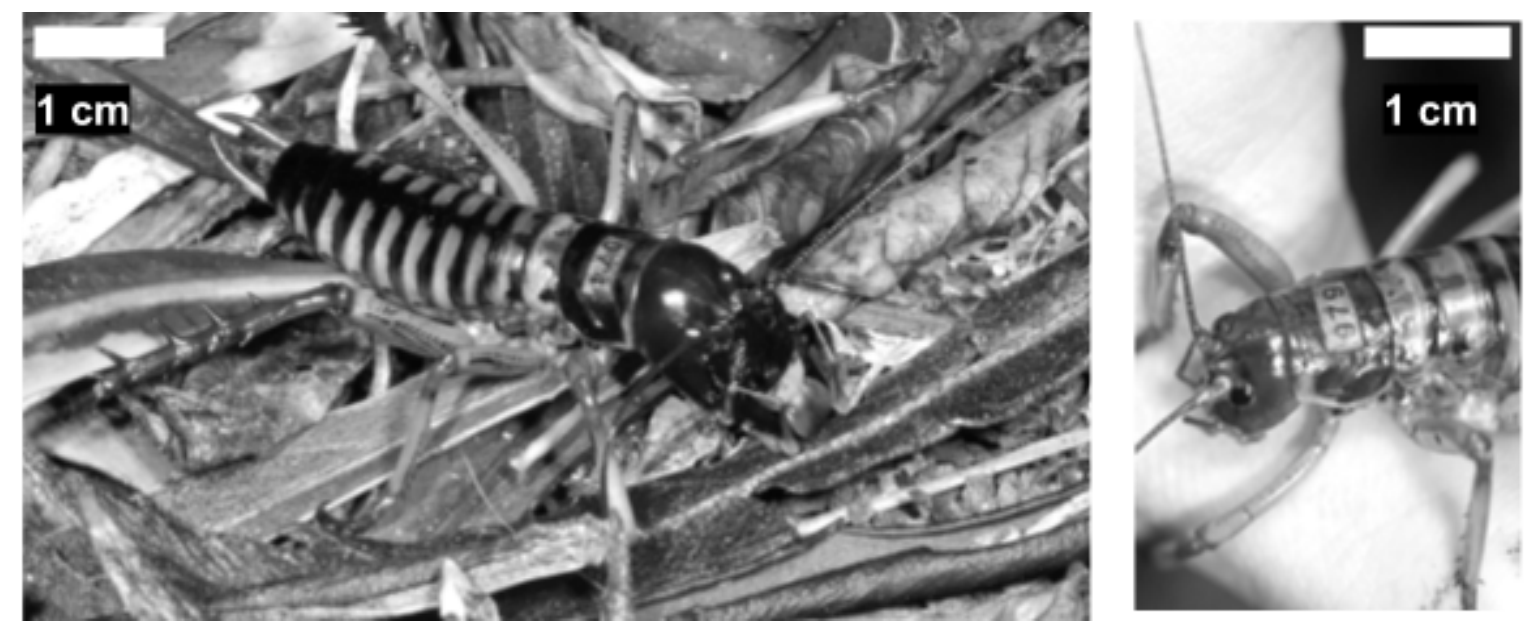

Figure 2.3 Adult male (left) and female (right) on Matiu/Somes Island marked using numbered tags attached to individual's pronotum. (Photographs by A.S. Dixson and E. Greene)

\subsubsection{Statistical methods for mark recapture study:}

Longevity of adult males and females was estimated as the "mean minimum life-span" (MML) which is calculated by dividing the sum of days survived by all recaptured individuals by the total number recaptured (Ehrlich \& Gilbert 1973, 
Zalucki and Kitching 1984). Following the methodology developed during mark recapture studies of alpine weta (Hemideina maori), I first eliminated from the dataset all individuals that were not recaptured at least once (Leisnham and Jamieson 2002; Leisnham et al. 2003). The program MARK 2.1 (Department of Fishery and Wildlife, Colorado State University, Fort Collins, USA) was used to model adult survival and recapture rates. Other statistical tests were made using $R$ statistical software (http://www.r-project.org).

Capture-recapture estimation is based on probabilistic models for events that give rise to a capture/encounter history (Nichols 2005). The basic input to MARK is the encounter history for each animal, with the Cormack-Jolly-Seber (CJS) model (Lebreton et al. 1992) providing survival $(\varphi)$ and recapture ( $p$ ) parameter estimates using data from marked animals which were subsequently re-encountered (White and Burnham 1999). MARK 2.1 computes estimates of the Cormack-Jolly-Seber-model parameters (survival $(\varphi)$ and recapture probability $(p)$ ) via numerical maximum-likelihood techniques and allows a comparison of models using Akaike's information criterion (AICc) (Akaike, 1985; Burnham, White \& Anderson, 1995; White \& Burnham, 1999).

I used open-population models, which allow for the processes of birth, death and migration, meaning the population size can change during the study (Pollock and Alpizar-Jara 2005). Because it is difficult to distinguish the effects of death and emigration on $\varphi$ and $p$ in an open population, $\varphi$ may not exactly reflect survival. In the present study I found no evidence of migration between different forest patches simultaneously monitored on Matiu/Somes Island and emigration out of the island is (near) impossible. As such the term 'apparent survival' to describe the probability parameter $\varphi$ seems warranted (White and Burnham 1999). Based on the approach used with alpine weta (H. maori) (Leisnham et al. 2003; Joyce et al. 2004), I considered five factors that could affect the probability of a weta being captured or detected. The five factors were: sex, time (differences among months), age (based on results of mean minimum lifespan analysis), average monthly temperature and season (Table 2.1; Appendix B). To determine whether head size has an effect on 
male survival and longevity, I performed a second analysis in MARK using only males ( $n=521$ uniquely marked). I modeled the effects of adult instar number as well as head length as a covariate on $\varphi$ and $p$.

Table 2.1. Notation for either daily survival $(\varphi)$ or recapture $(p)$ probability parameters in the Cormack-Jolly-Seber (CJS) models of the adult population on Matiu/Somes Island over 42 months.

\begin{tabular}{|c|c|}
\hline Notation & Model description \\
\hline$\Phi$ or $p$ & Constant $\varphi$ or $p$ \\
\hline$\varphi$ or $p$ sex & $\varphi$ or $p$ varies between sexes \\
\hline$\varphi$ or $p$ time & $\varphi$ or $p$ varies over time \\
\hline$\varphi$ or $p$ time+sex & $\begin{array}{c}\varphi \text { or } p \text { varies with time and between sexes } \\
\text { with a constant difference between sexes }\end{array}$ \\
\hline$\varphi$ or $p$ time*sex & $\begin{array}{c}\varphi \text { or } p \text { varies with time and between sexes } \\
\text { without a constant difference between sexes }\end{array}$ \\
\hline$\varphi$ or $p$ season & $\varphi$ or $p$ varies between seasons \\
\hline$\varphi$ or $p$ temperature & $\varphi$ or $p$ varies with temperature \\
\hline$\varphi$ or $p$ temperature+sex & $\begin{array}{r}\text { or } p \text { varies with temperature and between sexes with } \\
\text { a constant difference between sexes }\end{array}$ \\
\hline$\varphi$ or $p$ temperature*sex & $\begin{array}{r}\varphi \text { or } p \text { varies with temperature and between sexes } \\
\text { without a constant difference between sexes }\end{array}$ \\
\hline$\varphi$ or $p$ season+sex & $\begin{array}{c}\varphi \text { or } p \text { varies with season and between sexes with } a \\
\text { constant difference between sexes }\end{array}$ \\
\hline$\varphi$ or $p$ season*sex & $\begin{array}{r}\varphi \text { or } p \text { varies with season and between sexes without a } \\
\text { constant difference between sexes }\end{array}$ \\
\hline
\end{tabular}

\subsection{Results:}

\subsubsection{Mean minimum life span:}

I tested differences in the mean minimum lifespan for adult males and females using

a Welch two sample t-test. This test corrects for unequal variances in the two groups by adjusting the degrees of freedom (Yuen 1974). Contrary to my expectations, 
mean minimum lifespan (MML) was significantly greater in males than in females $(t=$ 4.1472, df = 804.697, $P<0.0001)$.

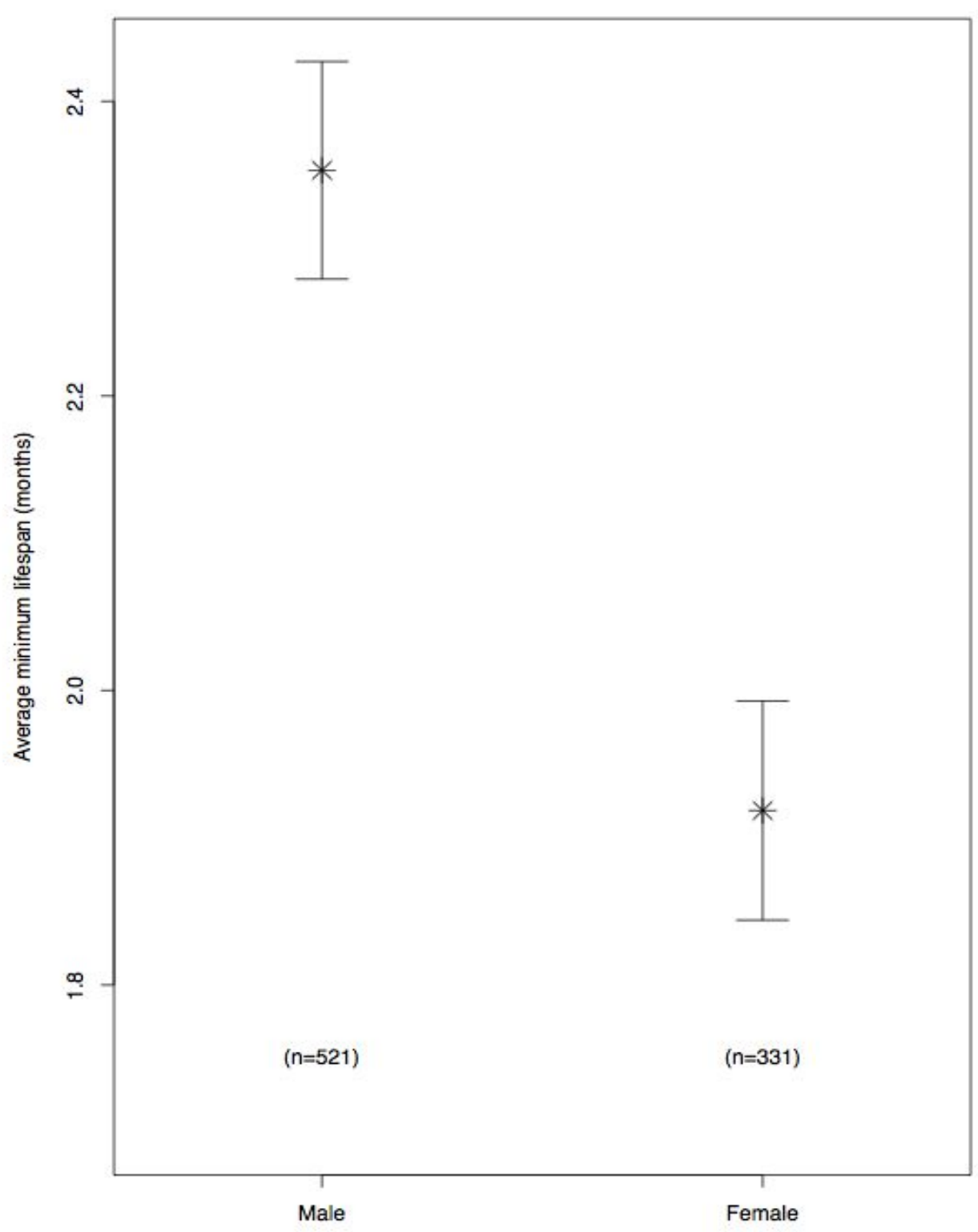

Figure 2.4: Average minimum adult lifespan, in months, of males $(n=521)$ and females $(n=331)$.

The minimum life span means ( \pm standard error) were 2.35 ( \pm 0.07 ) months for males and 1.92 ( \pm 0.07) months for females (Figure 2.4). MML in this case represents the number of months following sexual maturity or adult lifespan. Figure 2.5 shows the relative frequencies of recapture rates for males and females. The oldest recaptured individual male and female were 12 and 10 months respectively 
and there was a higher relative frequency of males that lived 8 months or more (Figure 2.5).
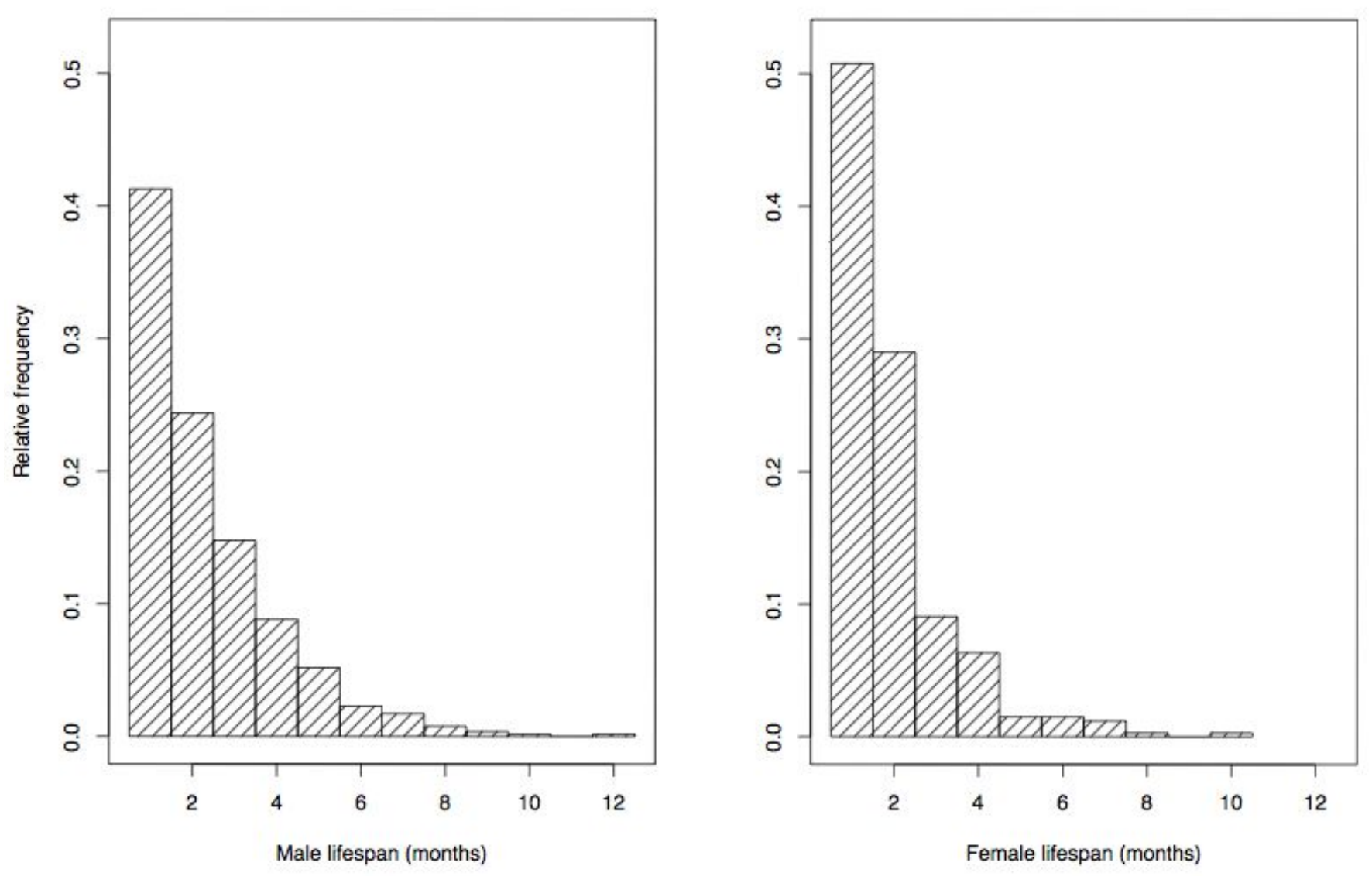

Figure 2.5. Relative frequency of adult males and females with mean minimum lifespan (MML) ranging from 1 to 12 months. N.b. 0.5 is equivalent to $50 \%$ as a measure of relative frequency.

I found no difference in mean minimum life span between males maturing after 8, 9 or 10 nymphal instars $\left(F_{2,518}=0.33, P=0.72\right)$. Mean minimum lifespan ( \pm standard error $)$, in months, for $8^{\text {th }}$ instar males $=2.39( \pm 0.12)$, for $9^{\text {th }}$ instar males $=2.32( \pm$ $0.09)$, and for $10^{\text {th }}$ instar males $=2.60( \pm 0.45)$ (Figure 2.6). Size categories for each alternative adult male instar were based on Spencer (1995; Appendix C). 


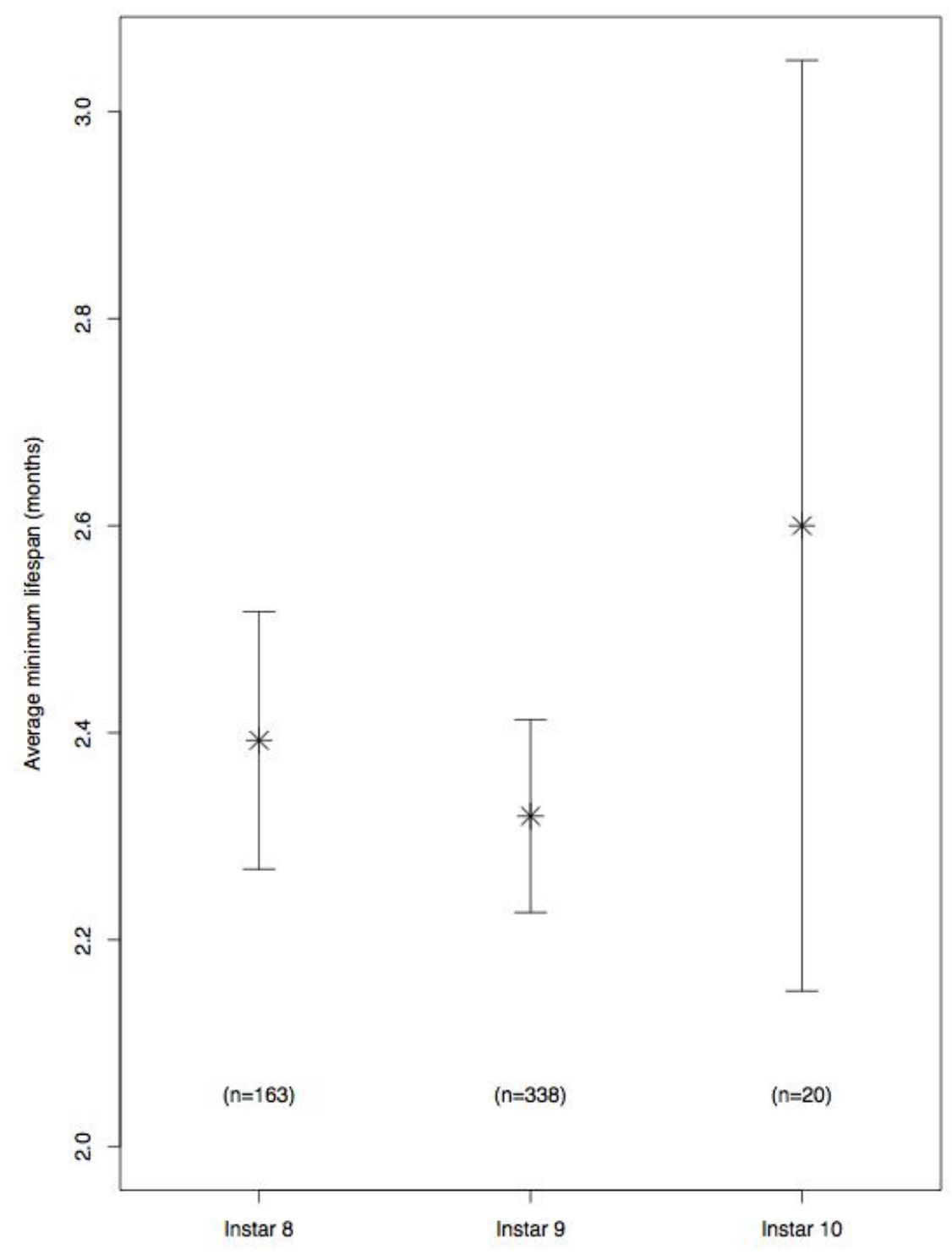

Figure 2.6. Average minimum life span, in months, of males maturing after eight, nine or ten nymphal instars.

\subsubsection{Adult male and female survival and recapture estimates.}

A total of 852 adult weta ( $n=521$ males, $n=331$ females) were uniquely marked in artificial galleries over 42 encounter occasions in consecutive months (July 2000 December 2003). The best-fit model for the data set comparing male and female survival and recapture probabilities was $\varphi_{\text {time+sex }} p_{\text {time*sex }}($ Table 2.2). This model states 
that survival varied over time with a constant difference between the sexes, while recapture probability varied over time without a constant difference between sexes (Table 2.1). The conditional probability $\varphi$ is the standard survival parameter used in capture-recapture models (McCallum 2000); it is the probability of an individual animal being alive one month later given that it is alive at time $t$. I derived estimates of survival rates (averaged over time) for adult males and females using the model $\varphi_{\text {sex }} p_{\text {time*sex }}$ (Table 2.2). Survival estimates $(\varphi)$ over 42 months were 0.564 (confidence intervals $0.535-0.593$ ) for males and 0.439 (confidence intervals 0.402 - 0.477) for females. This result means that on average, over all times, $56.4 \%$ of males and $43.9 \%$ of females survived from one month to the next. The difference in survivorship between males and females is significant at the $5 \%$ level because of non-overlapping 95\% confidence intervals (Alonso et al. 2015). There was also significant fluctuation of survival rate $(\varphi)$ over time for both males and females because the best model $\varphi_{\text {time+sex }} p_{\text {time*sex }}(\Delta \mathrm{AIC}=0)$ was chosen over $\varphi_{\text {sex }} p_{\text {time*sex }}(\Delta \mathrm{AIC}$ $=99.3657$ ) (Table 2.2). Some of the fluctuation could be explained by replacing time with season in the model: $\varphi_{\text {season+sex }} p_{\text {timesex }}(\Delta \mathrm{AIC}=20.1568)$ (Table 2.2 and Figure 2.9). The large $\triangle A I C$ values are to be expected because of the large dataset with the statistical power to detect even small effects of time, sex, season and temperature on $\varphi$ and $p$. 
Table 2.2 Results of CJS mark-recapture analysis using the program MARK to model the effects of group (male vs. female) and time (42 monthly intervals) on survival $(\varphi)$ and recapture $(p)$ probabilities. I also modeled the effects of season and temperature on $\varphi$ and $p$.

\begin{tabular}{|c|c|c|c|c|c|}
\hline Model & AICc & $\Delta \mathbf{A I C c}$ & $\begin{array}{c}\text { AICc } \\
\text { weight }\end{array}$ & $\begin{array}{c}\text { No. } \\
\text { Parameters }\end{array}$ & Deviance \\
\hline$\varphi($ time + sex $) p\left(\right.$ time ${ }^{*}$ sex $)$ & 3289.1600 & 0.0000 & 0.97882 & 54 & 3177.9247 \\
\hline $\begin{array}{c}\varphi(\text { temperature+sex }) \\
\mathrm{p}\left(\text { time }^{*} \mathrm{sex}\right)\end{array}$ & 3296.9530 & 7.7930 & 0.01988 & 45 & 3204.7091 \\
\hline$\varphi($ time+sex $) p($ sex $)$ & 3302.6622 & 13.5022 & 0.00114 & 27 & 3247.8506 \\
\hline$\varphi$ (time+sex) $p($ season*sex $)$ & 3307.5012 & 18.3412 & 0.00010 & 33 & 3240.2928 \\
\hline$\varphi$ (season+sex) p(time*sex) & 3309.3168 & 20.1568 & 0.00004 & 38 & 3231.7164 \\
\hline$\varphi($ time+sex $) p($ time + sex $)$ & 3314.6586 & 25.4986 & 0.00000 & 48 & 3216.1049 \\
\hline$\varphi($ time+sex $) p()$. & 3315.7917 & 26.6317 & 0.00000 & 26 & 3263.0385 \\
\hline$\varphi\left(\right.$ time ${ }^{*}$ sex $) p($ time + sex $)$ & 3316.7073 & 27.5473 & 0.00000 & 61 & 3190.5717 \\
\hline$\varphi($ sex $) p($ time+sex $)$ & 3322.6094 & 33.4494 & 0.00000 & 25 & 3271.9123 \\
\hline$\varphi$ (time+sex) $p$ (time) & 3323.6261 & 34.4661 & 0.00000 & 46 & 3229.2812 \\
\hline$\varphi$ (time) $p$ (time+sex) & 3328.7518 & 39.5918 & 0.00000 & 43 & 3240.7031 \\
\hline$\varphi($ time $) \mathrm{p}($ sex $)$ & 3340.4831 & 51.3231 & 0.00000 & 33 & 3273.2747 \\
\hline$\varphi\left(\right.$ time* ${ }^{*}$ ex $) p($ sex $)$ & 3341.3717 & 52.2117 & 0.00000 & 58 & 3221.6359 \\
\hline$\varphi$ (time) $p()$. & 3344.0314 & 54.8714 & 0.00000 & 32 & 3278.8947 \\
\hline$\varphi($ sex $) p($ sex $)$ & 3346.4761 & 57.3161 & 0.00000 & 4 & 3338.4549 \\
\hline$\varphi() p.($ time + sex $)$ & 3348.4096 & 59.2496 & 0.00000 & 25 & 3297.7125 \\
\hline$\varphi$ (time) $p$ (time) & 3354.0455 & 64.8855 & 0.00000 & 53 & 3244.9296 \\
\hline$\varphi\left(\right.$ time $^{*}$ sex $) p()$. & 3356.6874 & 67.52741 & 0.00000 & 57 & 3239.0802 \\
\hline$\varphi\left(\right.$ age $^{*}$ sex $) p($ sex $)$ & 3358.3012 & 69.1412 & 0.00000 & 22 & 3313.7594 \\
\hline$\varphi\left(\right.$ time $^{*}$ sex $) p\left(\right.$ time $^{*}$ sex $)$ & 3361.1339 & 71.9739 & 0.00000 & 95 & 3160.9723 \\
\hline$\varphi(\operatorname{sex}) p()$. & 3362.0556 & 72.8956 & 0.00000 & 3 & 3356.0429 \\
\hline$\varphi$ (time) $p\left(\right.$ time ${ }^{*}$ sex $)$ & 3365.9007 & 76.7407 & 0.00000 & 79 & 320.9211 \\
\hline$\varphi\left(\right.$ time $^{*}$ sex $) p($ time $)$ & 3368.3274 & 79.1674 & 0.00000 & 78 & 3205.5261 \\
\hline$\varphi(.) \mathrm{p}(\mathrm{sex})$ & 3369.7682 & 80.6082 & 0.00000 & 3 & 3363.7555 \\
\hline$\varphi($ age $) p($ sex $)$ & 3369.8458 & 80.6858 & 0.00000 & 14 & 3341.6219 \\
\hline$\varphi($ sex $) p$ (time) & 3373.5408 & 84.3808 & 0.00000 & 42 & 3287.5863 \\
\hline$\varphi() p.()$. & 3374.9376 & 85.7776 & 0.00000 & 2 & 3370.9312 \\
\hline$\varphi($ age $) p()$. & 3378.9562 & 89.7962 & 0.00000 & 13 & 3352.7623 \\
\hline$\varphi()$.$p (time)$ & 3383.2330 & 94.0730 & 0.00000 & 39 & 3303.5474 \\
\hline$\varphi(\operatorname{sex}) p\left(\right.$ time* ${ }^{*}$ ex $)$ & 3388.5257 & 99.3657 & 0.00000 & 72 & 3238.7435 \\
\hline$\varphi() p.\left(\right.$ time* $e^{*}$ ex & 3412.8342 & 123.6742 & 0.00000 & 71 & 3265.2135 \\
\hline
\end{tabular}

\subsubsection{Male weapon size and survival estimates.}

To determine whether weapon size (head length) has an effect on male survival and longevity I performed a second analysis in MARK using only males $(n=521$ uniquely marked). I modeled the effects of adult instar number as well as head length as a covariate on $\varphi$ and $p$. The best-fit model for the data set comparing $8^{\text {th }}, 9^{\text {th }}$ and $10^{\text {th }}$ instar males, and separately modeling head length (weapon size) as a covariate, was $\varphi_{H L} p_{t}$ (Table 2.3). The subscripts ${ }_{H L}$ and ${ }_{t}$ refer to head length in males and time 
respectively. The biological interpretation of this model $\left(\varphi_{\mathrm{HL}} p_{t}\right)$ is that male survivorship $(\varphi)$ was most influenced by weapon size and the probability of recapture (p) was most influenced by time. Grouping males as $8^{\text {th }}, 9^{\text {th }}$ or $10^{\text {th }}$ instar adults (Spencer 1995) did not lead to models with better explanatory power. However, when weapon size was modelled separately, the beta ( $($ ) estimate of survivorship $(\varphi)$ as a function of weapon size $(\mathrm{HL})$ was positive. This result indicates that males with larger weapon size had higher survivorship than males with smaller weaponry. This positive relationship was significant at the $5 \%$ level, as the $95 \%$ confidence interval for $B$ is $(0.0122,0.0185)$, which excludes zero. The range of weapon size and body size in the population is shown in figure 2.7 .

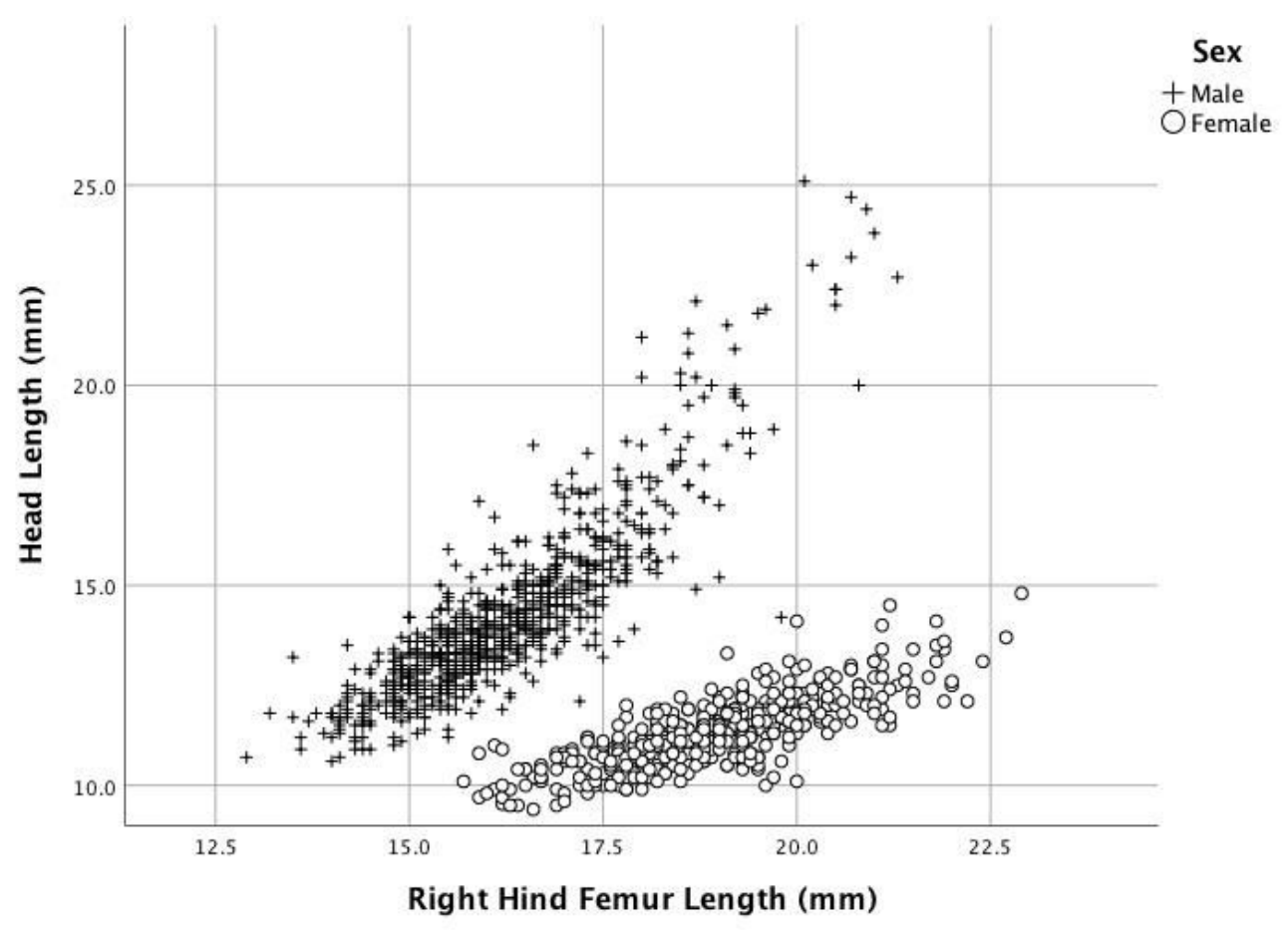

Figure 2.7 Variation in head length and body size in 521 adult males and 331 adult female Wellington tree weta over 42 months on Matiu/Somes Island. Individuals were measured once as adults when they were marked with a numbered tag. A line has not been fitted as the purpose of this graph is to show the characteristics of the population. 
Table 2.3. MARK analysis of the effects of three alternative adult male instar numbers (i.e. adult after 8,9 or 10 juvenile instars $=\mathrm{g}$ ) and 42 time increments $(\mathrm{t}$ ) on survival $(\varphi)$ and recapture $(p)$ probabilities. Head length $(H L)$, representing male weapon size, was modeled independently of instar number $(\mathrm{g})$ as a covariate to test the effects on $\varphi$ and $p$ probabilities.

\begin{tabular}{|c|c|c|c|c|c|}
\hline Model & AICc & $\triangle \mathrm{AICc}$ & $\begin{array}{c}\text { AICc } \\
\text { weight }\end{array}$ & $\begin{array}{c}\text { No. } \\
\text { Parameter } \\
\text { s }\end{array}$ & Deviance \\
\hline$\varphi(\mathrm{HL}) \mathrm{p}(\mathrm{t})$ & 4301.8334 & 0.000 & 0.38793 & 37 & 4226.6028 \\
\hline$\varphi(\mathrm{HL}) \mathrm{p}(\mathrm{t}+\mathrm{HL})$ & 4303.6895 & 1.8561 & 0.15336 & 38 & 4226.3918 \\
\hline$\varphi(g) p(t+g)$ & 4303.7060 & 1.8726 & 0.15210 & 41 & 4220.1961 \\
\hline$\varphi(t+g) p(g)$ & 4303.9262 & 2.0928 & 0.13624 & 40 & 4222.4889 \\
\hline$\varphi() p.(t+H L)$ & 4304.7728 & 2.9394 & 0.08922 & 38 & 4227.4751 \\
\hline$\varphi(\mathrm{t}+\mathrm{HL}) \mathrm{p}()$. & 4306.6781 & 4.8447 & 0.03441 & 37 & 4231.4475 \\
\hline$\varphi(t) p(H L)$ & 4307.5536 & 5.7202 & 0.02221 & 36 & 4234.3882 \\
\hline$\varphi(\mathrm{t}+\mathrm{HL}) \mathrm{p}(\mathrm{HL})$ & 4308.5327 & 6.6993 & 0.01361 & 37 & 4233.3021 \\
\hline$\varphi(t+H L) p(t)$ & 4311.5131 & 9.6797 & 0.00307 & 70 & 4167.0992 \\
\hline$\varphi(t) p(t+g)$ & 4312.1498 & 10.3164 & 0.00223 & 71 & 4165.6078 \\
\hline$\varphi(g) p(t)$ & 4312.6595 & 10.8261 & 0.00173 & 44 & 4222.9211 \\
\hline$\varphi(t) p(t+H L)$ & 4312.7657 & 10.9323 & 0.00164 & 70 & 4168.3518 \\
\hline$\varphi(\mathrm{t}+\mathrm{HL}) \mathrm{p}(\mathrm{t}+\mathrm{HL})$ & 4313.6180 & 11.7846 & 0.00107 & 71 & 4167.0760 \\
\hline$\varphi() p.(t)$ & 4313.6436 & 11.8102 & 0.00106 & 42 & 4228.0594 \\
\hline$\varphi(t) p()$. & 4319.1044 & 17.2710 & 0.00007 & 42 & 4233.5202 \\
\hline$\varphi(\mathrm{t}) \mathrm{p}(\mathrm{g})$ & 4319.6293 & 17.7959 & 0.00005 & 44 & 4229.8909 \\
\hline$\varphi(t) p(t)$ & 4330.3976 & 28.5642 & 0.00000 & 78 & 4168.9056 \\
\hline$\varphi() p.(t+g)$ & 4334.1521 & 32.3187 & 0.00000 & 31 & 4271.2861 \\
\hline$\varphi(g) p(t+g)$ & 4334.7245 & 32.8911 & 0.00000 & 33 & 4267.7442 \\
\hline$\varphi(t+g) p(t)$ & 4339.8947 & 38.0613 & 0.00000 & 80 & 4174.1141 \\
\hline$\varphi(g) p()$. & 4346.4279 & 44.5945 & 0.00000 & 4 & 4338.4106 \\
\hline$\varphi(g) p(g)$ & 4346.5367 & 44.7033 & 0.00000 & 6 & 4334.5004 \\
\hline$\varphi() p.()$. & 4346.590 & 44.7566 & 0.00000 & 2 & 4342.5848 \\
\hline$\varphi(\mathrm{HL}) \mathrm{p}(\mathrm{HL})$ & 4347.0114 & 45.1780 & 0.00000 & 2 & 4343.0062 \\
\hline$\varphi() p.(H L)$ & 4347.4039 & 45.5705 & 0.00000 & 2 & 4343.3987 \\
\hline$\varphi() p.(g)$ & 4347.8661 & 46.0327 & 0.00000 & 4 & 4339.8488 \\
\hline$\varphi(t+g) p(g)$ & 4352.8617 & 51.0283 & 0.00000 & 42 & 4267.2775 \\
\hline$\varphi(t+g) p()$. & 4353.3240 & 51.4906 & 0.00000 & 40 & 4271.8867 \\
\hline$\varphi(t+g) p(t+g)$ & 4361.7146 & 59.8812 & 0.00000 & 76 & 4204.5036 \\
\hline$\varphi\left(t^{\star} g\right) p(g)$ & 4372.2070 & 70.3736 & 0.00000 & 106 & 4149.9705 \\
\hline$\varphi\left(\mathrm{t}^{*} \mathrm{~g}\right) \mathrm{p}()$. & 4374.1525 & 72.3191 & 0.00000 & 104 & 4156.3058 \\
\hline$\varphi\left(t^{*} g\right) p(t+g)$ & 4385.2901 & 83.4567 & 0.00000 & 140 & 4087.1966 \\
\hline$\varphi\left(\mathrm{t}^{*} \mathrm{~g}\right) \mathrm{p}(\mathrm{t})$ & 4385.7949 & 83.9615 & 0.00000 & 139 & 4089.9662 \\
\hline$\varphi(g) p\left(t^{*} g\right)$ & 4389.6851 & 87.8517 & 0.00000 & 117 & 4143.1627 \\
\hline$\varphi() p.\left(t^{*} g\right)$ & 4395.5134 & 93.6800 & 0.00000 & 115 & 4153.4246 \\
\hline$\varphi(t+g) p\left(t^{*} g\right)$ & 4403.3137 & 101.4803 & 0.00000 & 151 & 4080.1695 \\
\hline$\varphi(t) p\left(t^{*} g\right)$ & 4405.3854 & 103.5520 & 0.00000 & 149 & 4086.8148 \\
\hline$\varphi(\mathrm{HL}) \mathrm{p}()$. & 4413.5206 & 111.6872 & 0.00000 & 2 & 4409.5154 \\
\hline$\varphi\left(t^{*} g\right) p\left(t^{*} g\right)$ & 4434.4548 & 132.6214 & 0.00000 & 191 & 4018.0372 \\
\hline
\end{tabular}




\subsubsection{Seasonal patterns on Matiu/Somes Island}

Looking at patterns in the appearance of nymphs, sub-adults and adults across 42 months of data reveals allows us to make inferences about the life history of Wellington tree weta. Seasonal variations in temperature and rainfall (Figure 2.8) are likely to affect tree weta and influence the optimal period of the year for reproduction.

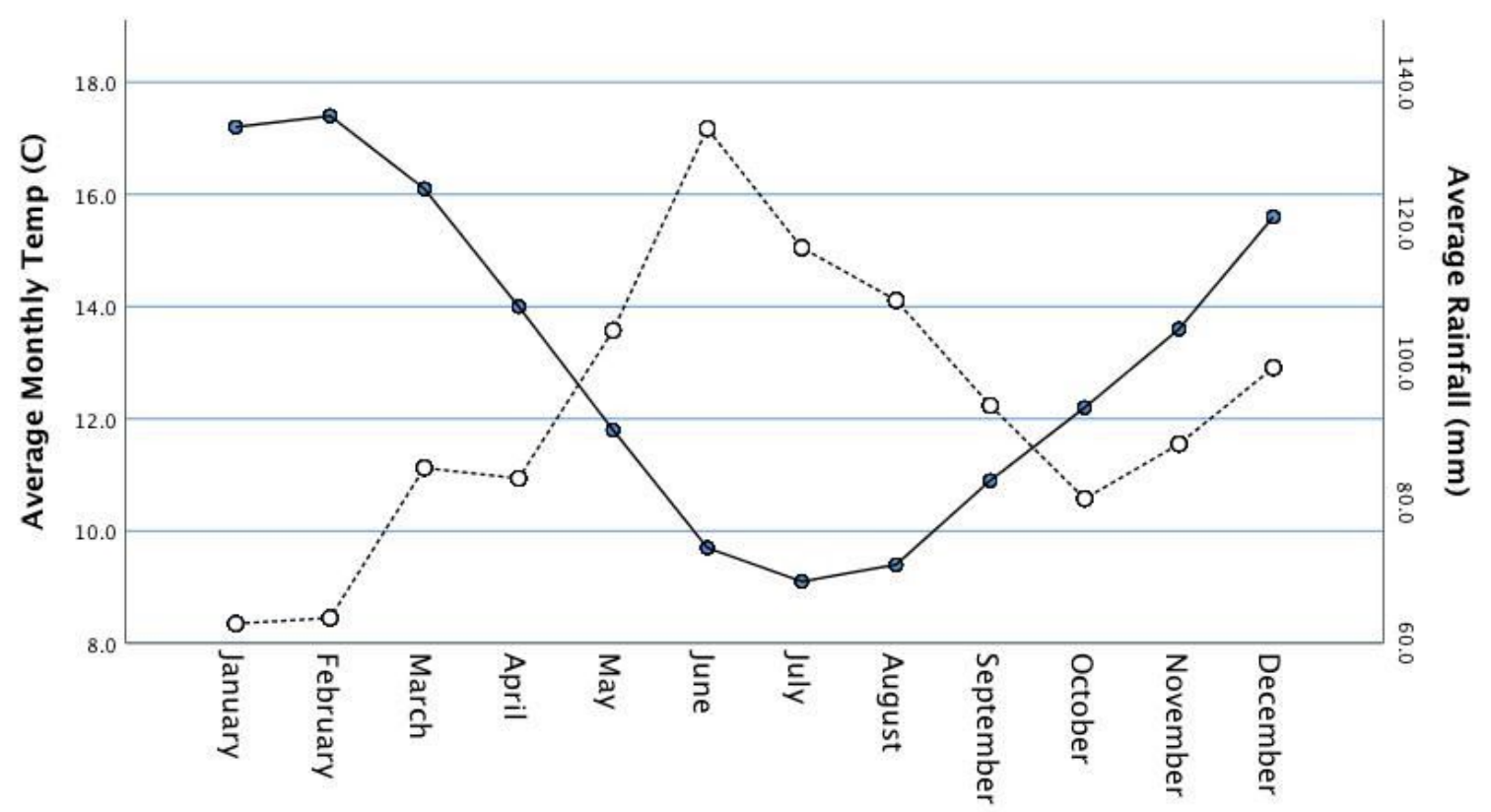

Months

Figure 2.8: Mean monthly temperature (solid line) and rainfall (dashed line) on Matiu/Somes Island. Data from NIWA New Zealand national climate database; Matiu/Somes Island weather recording station 1971 - 2000.

The largest numbers of newly marked males and females were recorded between December and May each year between December 2000 and December 2003 (Figure 2.9). An increase in the number of newly marked individuals in a month is an indication that more adults had recently reached maturity during that month, or that movement increased over the preceding month(s). Numbers of subsequently recaptured adults declined each year by June/July. The decline in number of recaptured individuals is likely to be an indication of mortality in the population. The peak numbers of adults coincides with the highest temperatures at the end of Spring and through the Summer (Figure 2.10). Estimates of mean minimum lifespan given above suggest that it is unlikely that females would survive to breed for two seasons 
but that some males might survive long enough to succeed in fertilizing eggs for two breeding seasons. The yearly pattern of peak numbers of adults suggests eggs are laid between approximately December and May each year and hatch during July, August and September, which are the coldest winter months with the highest rainfall (Figure 2.9 and Figure 2.10).
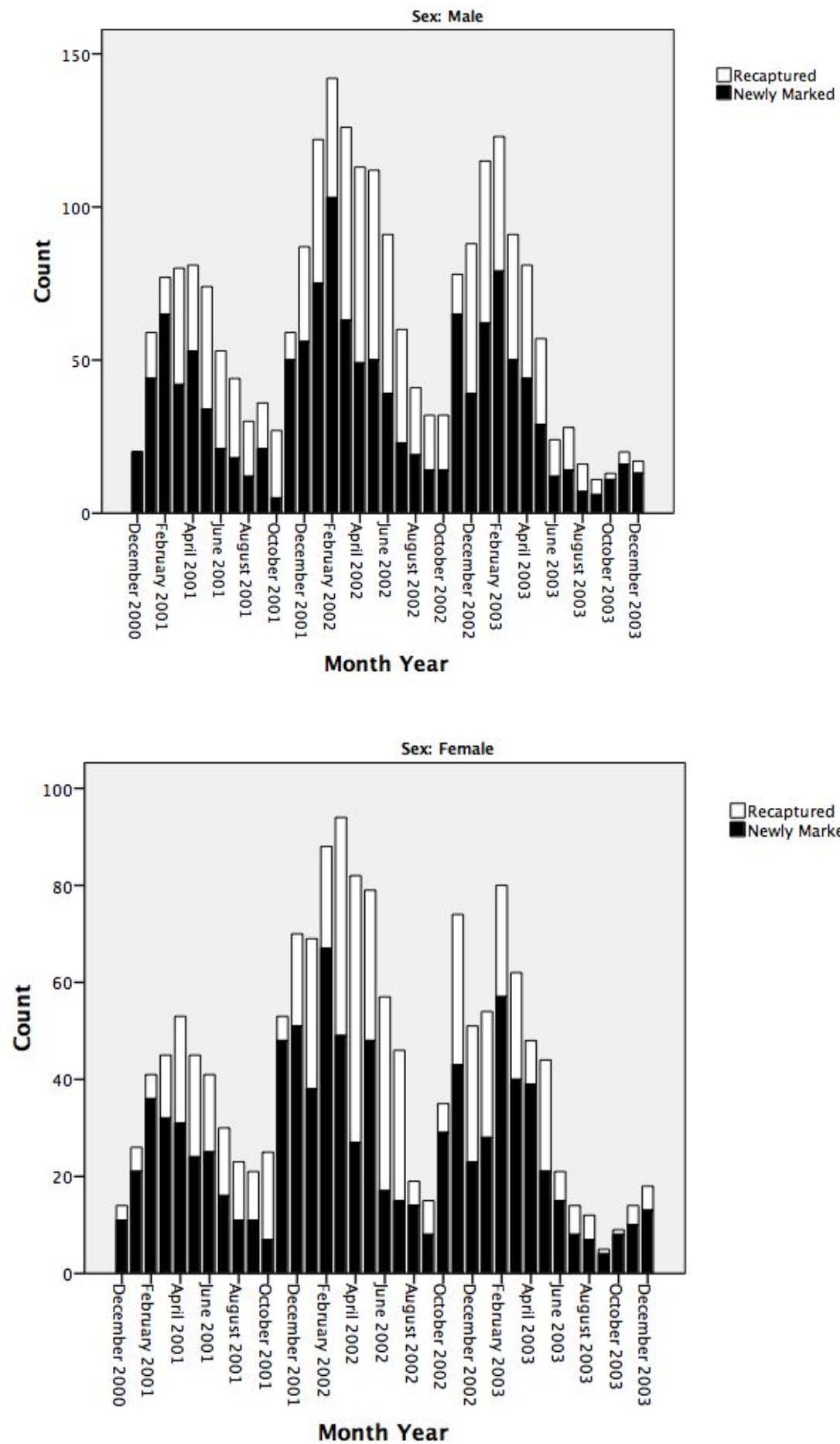

$\square$ Recaptured

Newly Marked

Figure 2.9 Seasonal patterns of newly marked and recaptured adult males and females. 


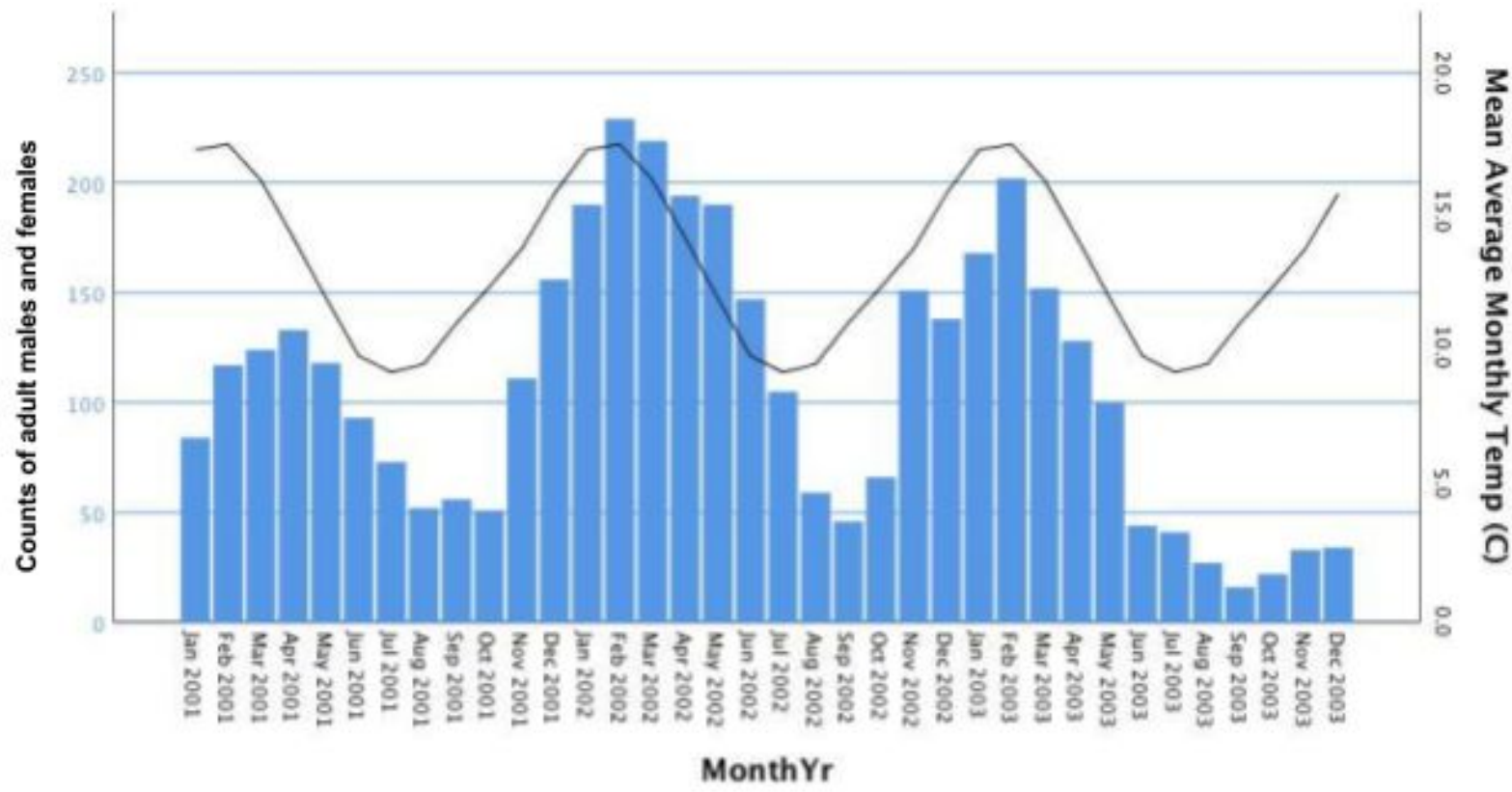

Figure 2.10: Monthly counts of adult males and females. The histogram shows both newly marked and recaptured over 3 years shown with monthly average temperature shown as a line.

The largest numbers of sub-adult (approximately instar 6 and above) were recorded between April and October, as temperature declines from autumn to winter (Figure 2.11). These individuals were between the 5th instar and the moult to adulthood; it is not possible to accurately record the exact instar during field measurements of tree weta and head length and body size measurements were not taken for these individuals. This pattern suggests that on Matiu/Somes Island, sub-adult males and females consistently reached the final molt and become adults between approximately September and November. The largest numbers of early instar nymphs (too small for their sex to be determined) were counted in summer between January and March each year (Figure 2.11). 


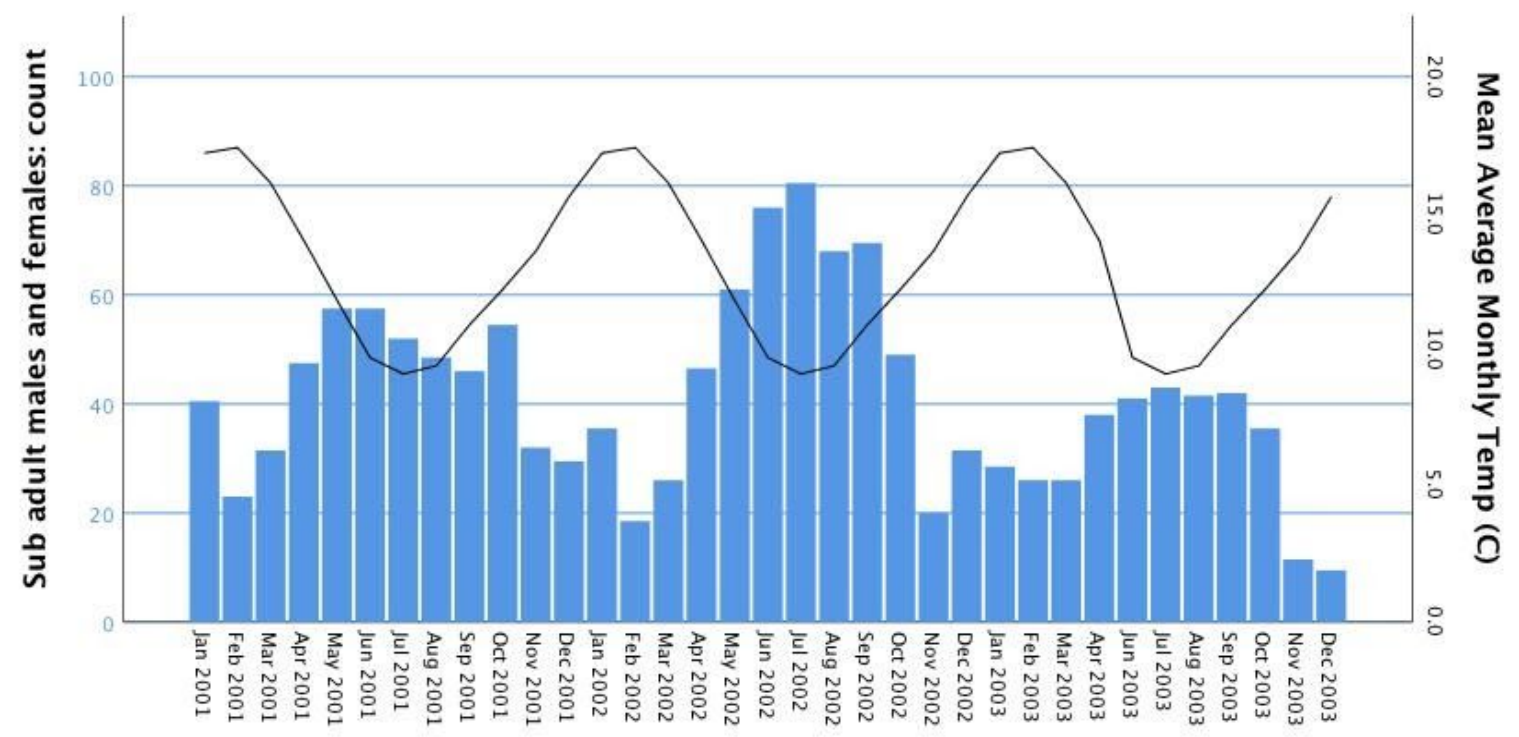

MonthYr

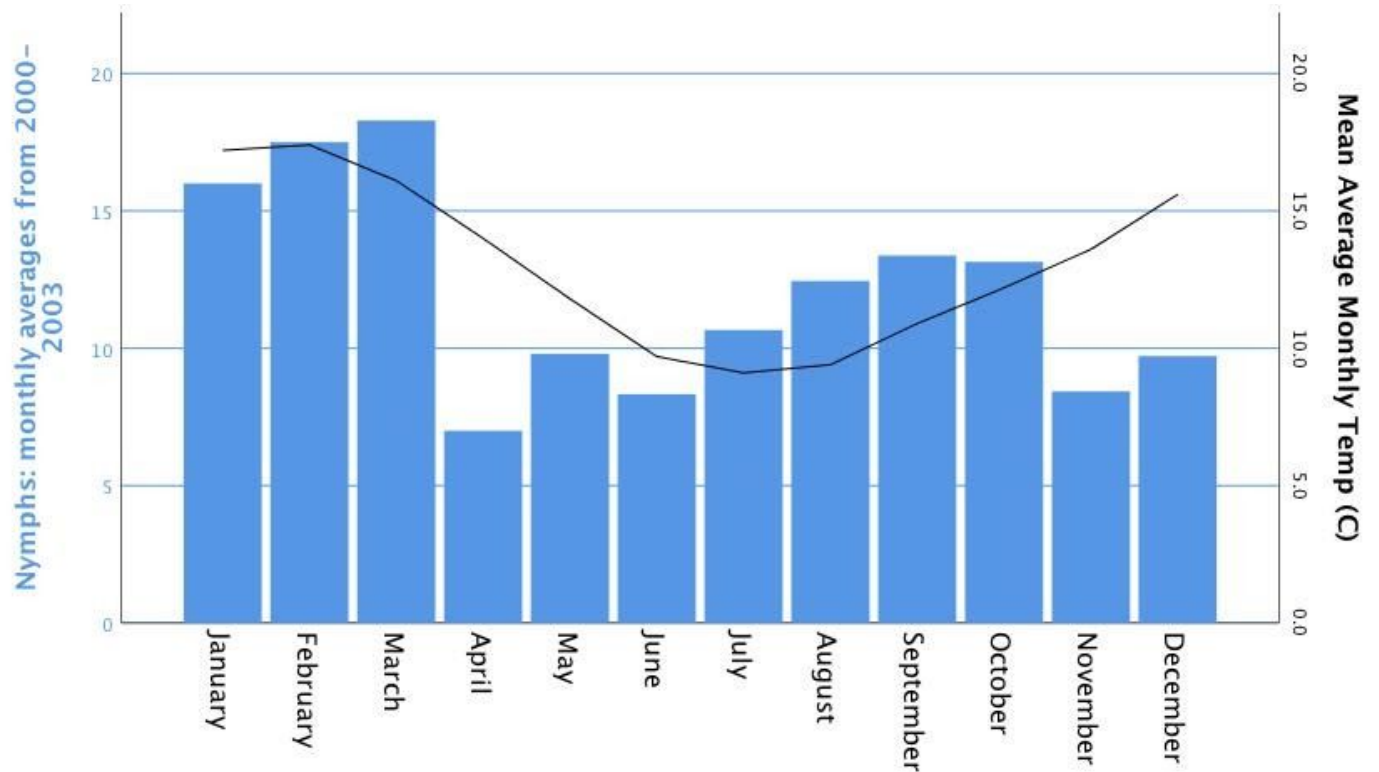

Figure 2.11: sub-adults counted each month (above) and average monthly counts of nymphs (below) males and females counts over three years. 


\subsection{Conclusions and discussion:}

\subsubsection{Survival and longevity}

In this mark-recapture study, individual $H$. crassidens were able to be monitored over the course of their entire lifespan as the artificial refuges could be monitored non-destructively. Given the relatively small total area of Matiu/Somes Island and of the forest fragment being monitored it is likely that this study presents a robust estimate of longevity of $H$. crassidens in this population. I found that male longevity estimated through mean minimum lifespan was greater females and the maximum recorded age of males (12 months) was also greater than that of females (10 months). Although adult male weta may engage in aggression over access to harems so females may incur significant damage in the course of their adult lives as a result of aggressive male mating behaviour (Kelly 2008b). Kelly and Jennions (2009) demonstrated that field-collected $H$. crassidens males have a significantly greater immune response than females which may relate to evidence from this study of reduced longevity in female tree weta. Perhaps as part of life history trade offs throughout development females might benefit by investing resources into egg production that would otherwise be invested into immune response as adults (Zera and Harshman 2001). However, Griffin (2011) found that although female tree weta fed additional protein between approximately the 7th-10th instars increased their fat stores, they did not produce more eggs or higher quality eggs (Griffin 2011).

I found no significant difference in mean minimum lifespan between males reaching adulthood after an estimated eight, nine or ten juvenile instars. It is possible that 10th instar males were less well represented on Matiu/Somes Island compared to similar systems on Mana Island and Maud Island (table 4.3; Appendix A). However, the second analysis in MARK revealed that males with greater head length had higher survivorship than males with reduced weaponry. Given the potential for aggressive interactions among males (Kelly 2006a) perhaps less competitive males with smaller weaponry were less likely to return to the artificial galleries than females as a result of alternative behavioral strategy of "sneak" rather than "guard" (Wilson and Kelly 
2019). The likelihood of males engaging in combat is negatively correlated with the difference in weapon size between opponents (Kelly 2006a). It is possible that males with larger weaponry suffered less from the costs of fighting for harems as other males tend to flee when the asymmetry in weapon size is too great, this could lead to increased mortality for males with the more exaggerated weaponry. The distribution of head length to body size in the population studied on Matiu/Somes Island (Figure 2.7) suggests that there were more males with smaller weaponry and more similar to one another and fewer males with more exaggerated weapons. A higher frequency of males with smaller weaponry on Matiu/Somes Island may be related to smaller natural galleries that males with larger weaponry may struggle to enter (Kelly 2008a).

\subsubsection{Seasonal patterns}

My analysis in MARK revealed that season was an important factor in modelling the survival and recapture probabilities of male and female Wellington tree weta. Patterns of the appearance of newly marked adult males and females indicate that there may be a seasonal aspect to mating in $H$. crassidens on Matiu/Somes Island. In a study of Wellington tree weta in which gallery use patterns were monitored over two years Kelly (2006c) suggested that " $H$. crassidens appear not to have a defined mating system as they have been seen mating throughout the year". Wehi et al. (2013a) investigated seasonal patterns of artificial gallery use for a closely related

species of tree weta (Hemideina thoracica) and found that most harems were formed during summer while females tended to avoid cavities occupied by other females during other seasons. Further investigations are needed to confirm whether or not female Wellington tree weta show seasonal variation in their harem-forming behaviour.

The trends revealed in this study (Figure 2.12) suggest that mating and egg laying by $H$. crassidens on Matiu/Somes Island is likely to be concentrated in autumn as the average temperature is decreasing (March-May). This inference is consistent with findings from captive rearing studies (Spencer 1995; Barrett and Ramsey 1991; van 
Heugten 2015). Considering the data showing seasonal appearance of early stage nymphs on Matiu/Somes Island it is plausible that eggs may not hatch until mid to late spring (October-November) when mean daily temperature is between $12.2-13.6^{\circ} \mathrm{C}$. This inference is consistent with studies of captive rearing of $H$. crassidens reported laying dates of April-May and hatching dates of October-December (Spencer 1995, Barrett and Ramsey 1991). Leisnham et al. (2003) also observed seasonal patterns in the first appearance of $H$. maori nymphs, with peak numbers in January over several field seasons. The coldest winter months of the year on Matiu/Somes Island were July and August with mean daily minimum temperatures of $6.4^{\circ} \mathrm{C}$ and $6.8^{\circ} \mathrm{C}$ and maximum mean daily temperatures of $11.7^{\circ} \mathrm{C}$ and $12.1^{\circ} \mathrm{C}$ respectively. Many orthopterans faced with cold winters enter diapause either as adults or have an embryonic diapause where the eggs remain in a state of arrested development during the cold winter months and then hatch after a threshold for average daily temperature is reached (Whitman 2008; Danks 2006; Stringer 2001). The suggests that on Matiu/Somes Island, $H$. crassidens eggs potentially enter embryonic diapause during part of the coldest months of the year (July-August/September) coinciding with the highest rainfall (May-August). Hatching may then occur in October-November when the daily minimum and maximum temperature of 12.2 and $13.6^{\circ} \mathrm{C}$ could include a threshold temperature for hatching. Spencer (1995) noted that $H$. crassidens eggs would not hatch when reared at constant temperature indoor, suggesting that eclosion may be triggered by a change in temperature. A study where eggs were incubated with or without exposure to a full period of winter temperature showed that $H$. ricta requires a full winter in order to hatch (van Heugten 2015). Comparatively little is known about what triggers embryo development and hatching in other Hemideina species (Mckean et al. 2018; Stringer 2001). Temperature has also been shown to have a profound effect on growth in both $H$. crassidens and $H$. thoracica and their optimal growing periods depend on altitude and temperature (Minnards 2011; Minnards et al. 2014).

Figure 2.12 summarises observations from this chapter and inferences based on other studies to present a possible life cycle for $H$. crassidens on Matiu/Somes Island. It is important to acknowledge that this study is based on a single site and it 
has limitations in what can be extrapolated to a wider context. However, the patterns revealed as a result of the mark recapture study allow me to present some inferences about life history in $H$. crassidens although it is likely that there is significant variation in development time in individual weta. The effect of diet on development time of male $H$. crassidens is examined in chapter 4 of this thesis and I considered these results in constructing the life cycle diagram below (Figure 2.12).

\begin{tabular}{|c|c|c|c|c|c|c|c|c|c|c|c|c|c|c|c|c|c|c|c|c|c|c|c|c|c|c|c|c|c|c|c|c|}
\hline \multicolumn{5}{|c|}{ Highest temps. } & & & & & & & \multicolumn{4}{|c|}{ Highest temps. } & & & & & & & \multicolumn{6}{|c|}{ Highest temps. } & & & & & & \\
\hline \multicolumn{3}{|c|}{$\begin{array}{l}\text { Lowest } \\
\text { rainfall }\end{array}$} & & & & & & & & & $\begin{array}{l}\text { Lowes } \\
\text { rainfal }\end{array}$ & & & & & & & & & & \multicolumn{3}{|c|}{$\begin{array}{l}\text { Lowest } \\
\text { rainfall }\end{array}$} & & & & & & & & & \\
\hline & \multicolumn{6}{|c|}{ Peak new adults \# } & & & & & \multicolumn{6}{|c|}{ Peak new adults \# } & & & & & \multicolumn{6}{|c|}{ Peak new adults \# } & & & & & & \\
\hline & \multicolumn{6}{|c|}{ hatched in 1999} & & & & & & \multicolumn{5}{|c|}{ hatched in 2000} & & & & & \multicolumn{6}{|c|}{$\begin{array}{l}\text { from cohort hatched in } \\
\qquad 2001\end{array}$} & & & & & & \\
\hline & & & & & $\begin{array}{c}\text { Eggs } \\
\text { laid }\end{array}$ & & & & & \multicolumn{2}{|c|}{ Eggs hatch } & & $\begin{array}{l}\text { Peak } \\
\text { mphs }\end{array}$ & & \multicolumn{6}{|c|}{ Peak sub-adults \# } & & & & & \multicolumn{2}{|c|}{$\begin{array}{l}\text { Eggs } \\
\text { laid }\end{array}$} & & & & \multicolumn{3}{|c|}{ Eggs hatch } \\
\hline & & & & & $\begin{array}{l}\text { in } \\
2001 *\end{array}$ & & & & & \multicolumn{2}{|c|}{2001 *\# } & \multicolumn{9}{|c|}{ from cohort hatched in 2001} & & & & & & & & & & \multicolumn{3}{|c|}{$2003^{*}$} \\
\hline & & & & & & & & $\begin{array}{l}\text { Lowes } \\
\text { temps. }\end{array}$ & & & & & & & & & & $\begin{array}{l}\text { Lowest } \\
\text { temps. }\end{array}$ & & & & & & & & & & $\begin{array}{l}\text { Lowest } \\
\text { temps. }\end{array}$ & & & & \\
\hline & & & & & & ghest & rainfal & & & & & & & & & Highe & est rain & nfall & & & & & & & & High & hest rain & infall & & & & \\
\hline \multirow[t]{2}{*}{$\mathbf{N}$} & D & $\mathbf{J}$ & $\mathbf{F}$ & $\mathbf{M}$ & A $\mid n$ & M & $\mathbf{J}$ & A & $\mathbf{S}$ & $\mathbf{O}$ & $\mathbf{N} \mid \mathbf{D}$ & J & $\mathbf{F}$ & $\mathbf{M}$ & A 1 & $\mathbf{M} \mathbf{J}$ & $\mathbf{J}$ & A & $\mathbf{S}$ & 0 & $\mathbf{N}$ & D & $\mathbf{J} \mathbf{F}$ & $=\mathbf{M}$ & $\mathbf{A}$ & $\mathbf{M}$ & $\mathbf{J} \mid \mathbf{J}$ & $\mathbf{A}$ & $\mathbf{S}$ & $O N$ & $\mathbf{V} \mathbf{L}$ & 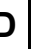 \\
\hline & & \multicolumn{10}{|c|}{2001} & \multicolumn{11}{|c|}{2002} & \multicolumn{10}{|c|}{2003} \\
\hline
\end{tabular}

Figure 2.12: Summary of results showing seasonal life history events for a single generation/cohort of tree weta on Matiu/Somes Island. The shaded boxes show events for a single generation.

* Based on Spencer 1995, Barrett and Ramsey 1991 and evidence presented in Chapter 4.

\# Based on data from the present study. 


\section{Chapter Three:}

\section{Use of artificial galleries by females and selection for exaggerated male weaponry in Wellington tree weta on Matiu/Somes Island.}

\subsection{Introduction}

Sexual selection is predicted to be strongest in polygamous mating systems where one or both sexes mate with multiple partners (Emlen and Oring 1977, Shuster and Wade 2003). This prediction has been supported by studies across taxa (Anderson 1994; Shuster and Wade 2003). In polygynous species where not all males are equally successful in finding mates and securing fertilizations, structures and strategies involved in competition for mates may be under intense sexual selection (Darwin 1871; Shuster and Wade 2003). Sexual selection drives the evolution of some of nature's most striking and highly exaggerated weapons and ornaments (Darwin 1871; Andersson 1994; Emlen and Nijhout 2000). Some examples in insects of structures used in competition for mates include the antlers and eye-stalks of flies from the family Diopsidae (Wilkinson and Dodson 1997), horns of scarab beetles (Emlen et al. 2005, 2007), and the pincers of earwigs (Eberhard and Gutierrez 1991). Male reproductive success may depend on individual investment in secondary sexual traits (Andersson 1994; Emlen 2008) or engaging in alternative reproductive strategies (Gross 1996).

In polygynous species where males use weapons to compete for mates, the distribution of females in the environment will also influence male reproductive success (Emlen and Oring 1977). Where females are found will be influenced by the 
availability of the resources they require for survival and reproduction. Exaggerated weaponry may increase male reproductive success in species where males use these traits to defend limited resources required by females (Emlen 2005). This kind of indirect competition for mates favors males that have a high level of resource holding potential (RHP) as a result of exaggerated weapons (Parker 1974). Males may also increase their reproductive success by competing directly for mates and engage in combat in order to access and mate with females (Clutton-Brock and Huchard 2013).

The Wellington tree weta (Hemideina crassidens) has a harem polygynandrous mating system, meaning that both males and females may have multiple partners. Male $H$. crassidens use their greatly exaggerated mandibles as weapons to compete for access to harems of females found in naturally occurring cavities in trees known as galleries. Male Wellington tree weta exhibit trimorphism in their adult mandible length thought to result from maturation after either 8, 9 or 10 instars (Spencer 1995, Kelly and Adams 2010). Sexual dimorphism is pronounced in $H$. crassidens as adult females all mature at the 10th instar (Spencer 1995) and show little variation in adult head size and shape. Female tree weta do not engage in aggressive intraspecific competition so head size and mandible length is not subject to sexual selection pressures (Kelly and Adams 2010). In this species, male resource holding potential is directly related to weapon size (Kelly 2006a). The resource in this case is a gallery containing an aggregation (a harem) of females. If males with the largest weaponry have the highest RHP, then these males will be afforded increased reproductive success if they can access larger galleries containing more females.

In this chapter I will investigate how males and females occupy artificial galleries on Matiu/Somes Island with the aim of testing the following predictions:

1. I predict that females will crowd into larger galleries more despite having the opportunity to distribute themselves more evenly across many smaller galleries. 
2. Given the seasonal patterns of increased gallery occupancy during summer in this field site (see chapter 2), I predict that females will be more likely to form harems during summer months.

3. I predict that there will be a positive correlation between male weapon size and the number of females occupying the same gallery as the male.

\subsection{Methods}

\subsubsection{Field experiment}

Hemideina crassidens were surveyed monthly from December 2000 to December

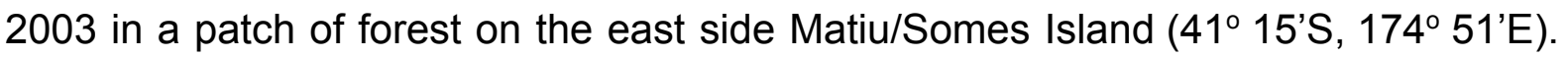
This field site was described in detail as part of the methods in chapter two of this thesis. Morphological measurements of head size and body size (right hind femur length) were made with Vernier dial callipers to the nearest $0.1 \mathrm{~mm}$, also as described in chapter two.

Gallery size was manipulated in the field experiment in three conditions. A large total number of artificial galleries were available, but there was a much lower proportion of large galleries compared to a larger number of small galleries. Ten numbered boxes (Figure 3.1a) were installed based on those designed by Trewick \& Morgan-Richards (2000). Each contained one medium-sized $(80 \mathrm{~mm} \times 50 \mathrm{~mm} \times 25 \mathrm{~mm})$ gallery and ten small $(80 \mathrm{~mm} \times 25 \mathrm{~mm} \times 25 \mathrm{~mm}$ ) numbered galleries (Figure $3.1 \mathrm{~b}$ and $\mathrm{c}$ ). A further ten large galleries $(30 \mathrm{~mm} \times 90 \mathrm{~mm} \times 60 \mathrm{~mm})$ similar in design to those used by Bowie et al. (2013) were contained in ten separate single boxes (Figure $3.1 \mathrm{~d}$ ). The diameter of the entrance tunnels for all artificial galleries was $25 \mathrm{~mm}$. In total, one hundred small galleries and ten medium-sized galleries, plus a further ten separate large galleries, were surveyed for occupation each month for 42 consecutive months. 
(a)

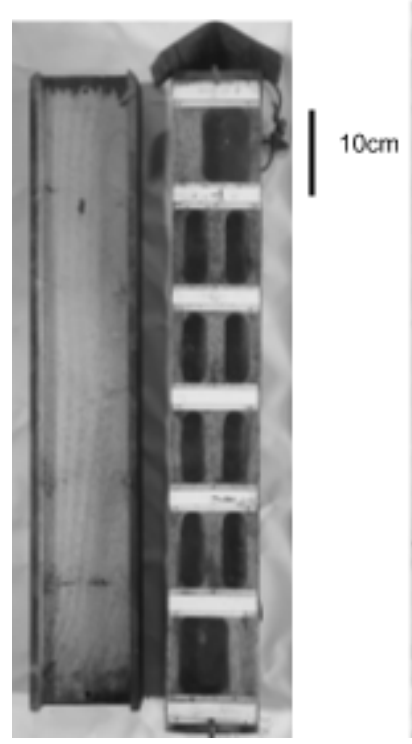

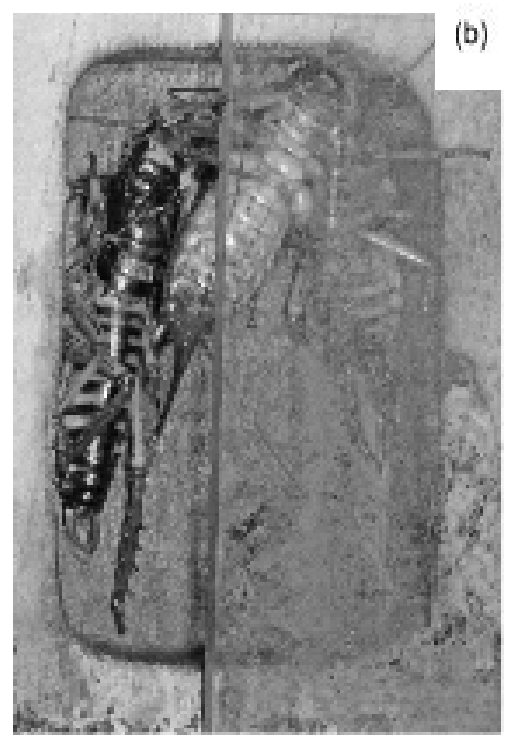

Large (25mm x $80 \mathrm{~mm}$ x 50mm) (b)

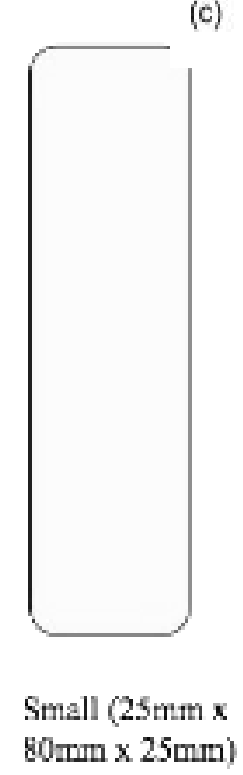

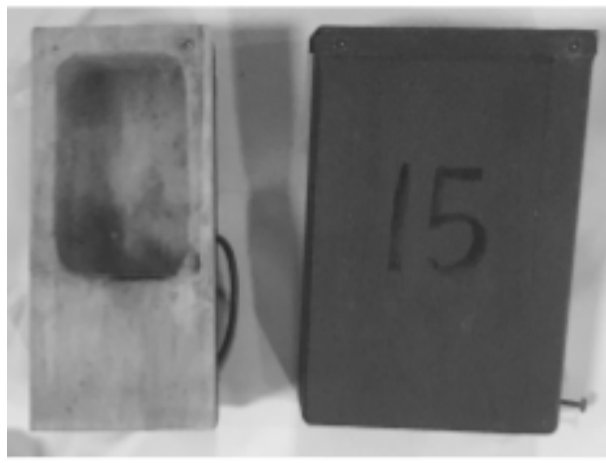

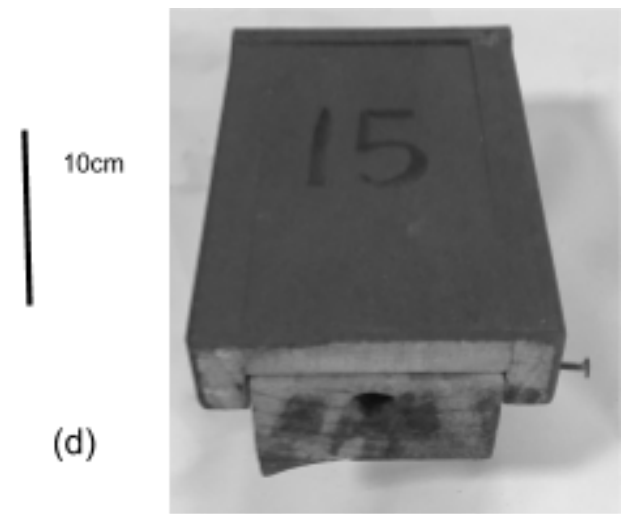

Single large gallery in separate boxes with dimensions $30 \mathrm{~mm} \times 90 \mathrm{~mm} \times 60 \mathrm{~mm}$

Figure 3.1 volumes of large (a) and small (b) and single large (c) artificial galleries. Photographs by A.S. Dixson 


\subsubsection{Statistical methods for calculating distribution of females in artificial galleries} $\left(\mathrm{m}, \mathrm{m}^{*}\right.$ and $\left.\mathrm{m}^{\prime}\right)$ :

The parameters $m$ (equation 1) and $m^{*}$ (equation 2) describe the spatial distribution of females across patches of resource (Shuster and Wade 2003, Wade 1995), in this case among a fixed number of artificial galleries of different volumes. Mean density $(m)$ is a simple measurement of the average number of individuals in each type of gallery. Mean crowding $\left(m^{*}\right)$ measures "the mean number per individual of other individuals in the quadrat" (Lloyd 1967 p.2) and has the potential to reveal more about how much crowding individuals experience each type of gallery. I calculated the average mean density of females $(m)$ and the average amount of crowding experienced by each female $\left(m^{*}\right)$ among artificial galleries with smaller or greater volumes (Figure 3.1).

I calculated $m^{*}$ (equation 2) for aggregations of females $\geq 1$ where a single adult male was present. Two parameters are used in calculating $m^{*}$, these are the mean density of females or mean density of females per patch, $m$ (equation 1) and the variance of female density among patches, $V_{m}$

$$
m=\sum \frac{m_{i}}{M}
$$

In equation 1 , the sum of all aggregations of females $\sum m_{i}$ is divided by the total number of patches, $M$. In this equation, $m_{i}$ is the density of females in the $i^{\text {th }}$ patch (artificial gallery) and $M$ is the total number of patches containing one or more females.

Mean female crowding, $m^{*}$, is experienced by each individual and depends on the total numbers of females present (Pielou 1977). The larger the value of $m^{*}$, the greater the degree of aggregation of females on units of resources, each unit in this case being an artificial gallery. The value $m^{*}$ (equation 2) is interpreted as "the 
number of other females that the average female experiences on her resource patch" (Shuster \& Wade 2003). Thus, $m^{*}$ measures the degree to which individuals, in this case females, tend to be clumped on resource patches. If $\mathrm{m}^{*}$ is greater than $\mathrm{m}$ in a type of experimental gallery then females will experience more mean crowding than is expected given the mean density of females.

$$
m^{*}=m+\left[\left(V_{m} / m\right)-1\right]
$$

As $\mathrm{m}^{*}$ only included harems of females where a male was also present, I also estimated mean crowding of females where a male was not present. I followed the approach used by Kelly (2005b) by calculating the value $m^{\prime}$, which is derived from the same equation as $m^{*}$ (equation 2) but includes all females censused and not just those that were found in harems where a male was also present. We may then compare $m^{\prime}$ (which includes aggregations of females without males) against $m^{*}$ (which describes harems that share a gallery with a single adult male). If the mean $m$ ' value is greater than $m^{*}$ for a gallery type then we may infer that many female aggregations have formed without a male being present at the time the data was collected (Kelly 2005, p.243).

\subsubsection{Harem size and weapon size of males}

Selection gradients for male head length (weapon size) and femur length (body size) were estimated using selection gradients to quantify the relationship between fitness (harem size) and each phenotypic trait (Kelly 2008a, Shuster and Wade 2003). Mean harem size was calculated for males residing in an artificial gallery with one or more females. To justify the use of harem size as a measure of male fitness, Kelly (2008a) demonstrated experimentally that male success in transferring spermatophores increased as a function of the number of females in a harem, indicating that the opportunity for males to mate increases with harem size.

I determined whether response variables differed between months or years (random factors) and gallery size treatments (fixed factor) by using a generalized linear model 
$(G L M)$. Linear $\left(\beta_{i}\right)$ selection gradients were estimated as the partial regression coefficients from multiple regressions, with harem size as the dependent variable and head size and body size (femur length) as the predictors. Statistical tests were made using R statistical software (http://www.r-project.org).

\subsection{Results}

\subsubsection{Distribution of females in artificial galleries: mean density of females and female mean crowding ( $m, m^{*}$ and $\left.m^{\prime}\right)$}

An analysis of deviance revealed a significant difference in mean density of females $(m)$ between gallery types $\left(X^{2}=70.51, P<0.0001\right)$. Tukey HSD tests showed that mean density of females $(m)$ are largest in artificial galleries with the highest volume (table 3.1). I found no significant difference in $m$ between months $\left(X^{2}{ }_{11}=12.38, P=\right.$ $0.336)$ or among the three years $\left(X_{2}^{2}=3.97, P=0.137\right)$. The interaction terms were also non-significant (year * month, $X^{2}{ }_{22}=7.816, P=0.998$, gallery size * month, $X^{2}$ $=15.82, P=0.825$, gallery size ${ }^{*}$ year, $\left.X^{2}{ }_{4}=3.193, P=0.526\right)$.

Mean crowding $\left(m^{*}\right)$ of females was significantly greater in both large galleries types compared with the small galleries $\left(F_{2,69}=25.89, P<0.000\right.$; table 3.1). In the present study, larger harems of females formed more often in the two larger gallery treatments. There was a low frequency of crowding and lower average harem size in the small gallery size treatment.

Female mean crowding $\left(m^{*}\right)$ exceeded mean density of females $(m)$ in the separate single large galleries only (Table 3.1). This result suggests that females in larger artificial galleries experienced more mean crowding than expected given the mean density of females in these galleries. There was no significant effect of month $\left(F_{11,69}\right.$ $=1.51, P=0.147)$ or year $\left(F_{2,69}=1.3598, P=0.264\right)$ on female mean crowding. 
Table 3.1. Mean density of females $(m)$ and female mean crowding $\left(m^{*}\right)$; mean differences between small, medium and large gallery types. Tukey HSD tests: multiple comparisons of means, $\mathbf{9 5 \%}$ family-wise confidence level.

\begin{tabular}{|c|c|c|c|c|c|}
\hline Gallery types & $\begin{array}{c}\text { Breeding } \\
\text { aggregations }\end{array}$ & Difference & Lower bound & Upper bound & $P$ value \\
\hline \multirow{2}{*}{ Large - Small } & $m$ & 0.978 & 0.364 & 1.592 & 0.008 \\
\cline { 2 - 6 } & $m^{*}$ & 1.716 & 0.453 & 2.980 & 0.016 \\
\hline $\begin{array}{c}\text { Single Large - } \\
\text { Small }\end{array}$ & $m$ & 1.199 & 0.585 & 1.813 & 0.003 \\
\cline { 2 - 6 } & $m^{*}$ & 2.121 & 0.858 & 3.384 & 0.006 \\
\hline $\begin{array}{c}\text { Single Large - } \\
\text { Large }\end{array}$ & $m$ & 0.221 & 0.393 & 0.835 & 0.518 \\
\cline { 2 - 6 } & $m^{*}$ & 0.405 & -0.858 & 1.668 & 0.585 \\
\hline
\end{tabular}

A comparison of $m^{*}$ values and $m^{\prime}$ values in the three gallery types (table 3.2) indicates that aggregations (harems) of $>1$ females are generally guarded by a single male. The calculation of $m^{*}$ includes only females that were found in a gallery defended by a single adult male, while $m$ ' includes all aggregations of females with and without males. Paired t-tests were all non-significant for $m^{*}$ versus $m^{\prime}$ in all years and gallery types.

Table $3.2 \mathrm{~m}, \mathrm{~m}^{*}$ and $\mathrm{m}$ ' Means and standard errors of average mean density of females $(m)$, female mean crowding in galleries occupied by a single adult male $\left(m^{*}\right)$, and galleries occupied by females with or without a male present $\left(m^{\prime}\right)$. (All results \pm 1 standard error).

\begin{tabular}{|c|c|c|c|c|}
\cline { 3 - 5 } \multicolumn{2}{c|}{} & $\begin{array}{c}\text { Small } \\
\text { Galleries }\end{array}$ & $\begin{array}{c}\text { Large } \\
\text { Galleries }\end{array}$ & $\begin{array}{c}\text { Single Large } \\
\text { Galleries }\end{array}$ \\
\hline \multirow{4}{*}{$\begin{array}{c}\text { Mean } \\
( \pm \text { SE })\end{array}$} & $\mathbf{n}$ & 264 & 76 & 88 \\
\cline { 2 - 5 } & $\boldsymbol{m}$ & $\mathbf{1 . 1 7}( \pm 0.02)$ & $\mathbf{2 . 1 4}( \pm 0.15)$ & $\mathbf{2 . 3 3}( \pm 0.17)$ \\
\cline { 2 - 5 } & $\boldsymbol{m}^{*}$ & $\mathbf{0 . 3 1}( \pm 0.03)$ & $\mathbf{1 . 9 7}( \pm 0.12)$ & $\mathbf{2 . 4 6}( \pm 0.16)$ \\
\cline { 2 - 5 } & $\boldsymbol{m}^{\prime}$ & $\mathbf{0 . 3 8}( \pm 0.05)$ & $\mathbf{1 . 5 0}( \pm 0.23)$ & $\mathbf{2 . 1 5}( \pm 0.30)$ \\
\hline
\end{tabular}

Although the presence of a single male with a group of females was shown to be the most frequent situation, there were a number of occasions where $>1$ male was found occupying a gallery. Details of the full survey of gallery occupation is shown in table 3.3 There were many occasions where more than one male was found occupying the same gallery either with or without females being present. 
Table 3.3. Occupation of gallery resources by males and females showing occasions where multiple males and females occupied the same gallery. This table is a summary of data across all months and all gallery types.

\begin{tabular}{c|c|c|c|c|c|c|c|c|}
\multicolumn{1}{c}{$\begin{array}{c}\mathbf{N} \\
\text { females }\end{array}$} & $\mathbf{0}$ & $\mathbf{1}$ & $\mathbf{2}$ & $\mathbf{3}$ & $\mathbf{4}$ & $\mathbf{5}$ & $\mathbf{6}$ & $\mathbf{7}$ \\
\hline $\mathbf{0}$ & 2414 & $\mathbf{8 0 6}$ & 184 & 29 & 3 & 1 & 0 & 0 \\
\hline $\mathbf{1}$ & $\mathbf{2 8 6}$ & $\mathbf{2 9 0}$ & 114 & 26 & 8 & 2 & 0 & 0 \\
\hline $\mathbf{2}$ & 31 & $\mathbf{7 9}$ & 29 & 10 & 3 & 2 & 0 & 1 \\
\hline $\mathbf{3}$ & 6 & $\mathbf{3 1}$ & 11 & 9 & 1 & 1 & 0 & 0 \\
\hline $\mathbf{4}$ & 1 & $\mathbf{1 6}$ & 8 & 1 & 1 & 1 & 0 & 0 \\
\hline $\mathbf{5}$ & 0 & $\mathbf{5}$ & 1 & 2 & 2 & 0 & 0 & 0 \\
\hline $\mathbf{6}$ & 0 & $\mathbf{5}$ & 4 & 4 & 0 & 0 & 0 & 0 \\
\hline $\mathbf{7}$ & 0 & $\mathbf{1}$ & 3 & 3 & 1 & 0 & 0 & 0 \\
\hline $\mathbf{8}$ & 0 & $\mathbf{0}$ & 2 & 0 & 0 & 0 & 0 & 0 \\
\hline $\mathbf{1 0}$ & 0 & $\mathbf{1}$ & 0 & 0 & 0 & 0 & 0 & 0 \\
\hline $\mathbf{1 1}$ & 0 & $\mathbf{0}$ & 0 & 0 & 0 & 0 & 1 & 0 \\
\hline
\end{tabular}

\subsubsection{Gallery use and male weaponry and body size}

I examined the relationship between gallery size and resident male weapon size by testing for differences in mean head length of males found residing in small, large and single large galleries (Figure 3.1). Mean male head length differed between the three gallery treatments $\left(F_{2,1331}=102.64, P<0.0001\right)$ as did mean femur length $\left(F_{2}\right.$, ${ }_{571}=43.228, P<0.0001$ ). The results of Tukey HSD tests (table 3.4 ) show that the two larger types of galleries contained males with larger weaponry and larger body size than did the small galleries.

Table 3.4. Tukey HSD tests showing the direction of difference in mean head length and mean femur length between the three gallery treatments. All differences were significant $(P<0.0001)$.

\begin{tabular}{|l|r|r|r|}
\cline { 2 - 4 } \multicolumn{1}{c|}{} & \multicolumn{1}{l|}{ Difference } & Lower bound & Upper bound \\
\hline Head length $(\mathbf{m m})$ & & & \\
\hline Single Large - Large & 1.079 & 0.485 & 1.672 \\
\hline Small-Large & -1.364 & -1.822 & -0.907 \\
\hline Small-Single Large & -2.443 & -2.877 & -2.009 \\
\hline Femur Length $(\mathbf{m m})$ & & & \\
\hline Single Large - Large & 0.537 & 0.002 & 1.072 \\
\hline Small-Large & -0.857 & 1.257 & -0.457 \\
\hline Small-Single Large & -1.394 & 1.791 & -0.998 \\
\hline
\end{tabular}


These results show that males residing in the largest available galleries containing the most females had the greatest mean head length and body size. Males residing in small galleries containing the fewest females had the smallest mean head length and body size.

Mean harem size was calculated for single males residing in an artificial gallery with one or more females. Both the large and single large galleries contained significantly larger harems than did small galleries $\left(F_{2,100}=17.814, P<0.0001\right)$. Mean harem size did not differ between months $\left(F_{11,100}=1.219, P=0.286\right)$ or years $\left(F_{2,100}=\right.$ 1.984, $P=0.143)$. The interactions between gallery size and month $\left(F_{22,65}=1.396, P\right.$ $=0.151)$, and gallery size and year $\left(F_{4,92}=1.509, P=0.206\right)$, were both non-significant.

I estimated selection gradients for male head length (weapon size) and femur length (body size) (Table 3.5). For each gallery size treatment I performed multiple regressions of harem size on head length and femur length. The complete multiple regression of harem size on head size plus body size was not significant in small $\left(F_{2,470}=0.117, P=0.890\right)$, large $\left(F_{2,47}=1.546, P=0.224\right)$, or single large galleries $\left(F_{2,48}=2.575, P=0.087\right)$. Partial regressions showed that larger harems in the two large gallery size treatments selected for larger head length in the two large gallery treatments (Table 3.4, Fig. 3.2a). Greater male body size was selected in the largest gallery size treatment in males with largest harems (Table 3.5, fig. 3.2b). 
Table 3.5. Standardized linear $(\beta \pm \mathrm{SE}$ ) selection gradients of harem size on head size and body size in male Hemideina crassidens. Estimated in 3 experimental gallery size treatments and results pooled over 42 monthly observations.

\begin{tabular}{|l|l|l|l|l|}
\hline & $\boldsymbol{n}$ & $\boldsymbol{\beta}$ & $\boldsymbol{B} \pm$ SE & $\boldsymbol{P}$ value \\
\hline Small galleries & & & & \\
Head size & 976 & 0.005 & 0.010 & 0.628 \\
Body size & 471 & -0.012 & 0.025 & 0.629 \\
\hline $\begin{array}{l}\text { Large galleries } \\
\text { Head size }\end{array}$ & 115 & 0.128 & 0.052 & 0.014 \\
Body size & 48 & 0.232 & 0.142 & 0.109 \\
\hline $\begin{array}{l}\text { Single large galleries } \\
\text { Head size }\end{array}$ & 130 & 0.231 & 0.055 & $<0.0001$ \\
Body size & 49 & 0.402 & 0.176 & 0.027 \\
\hline
\end{tabular}

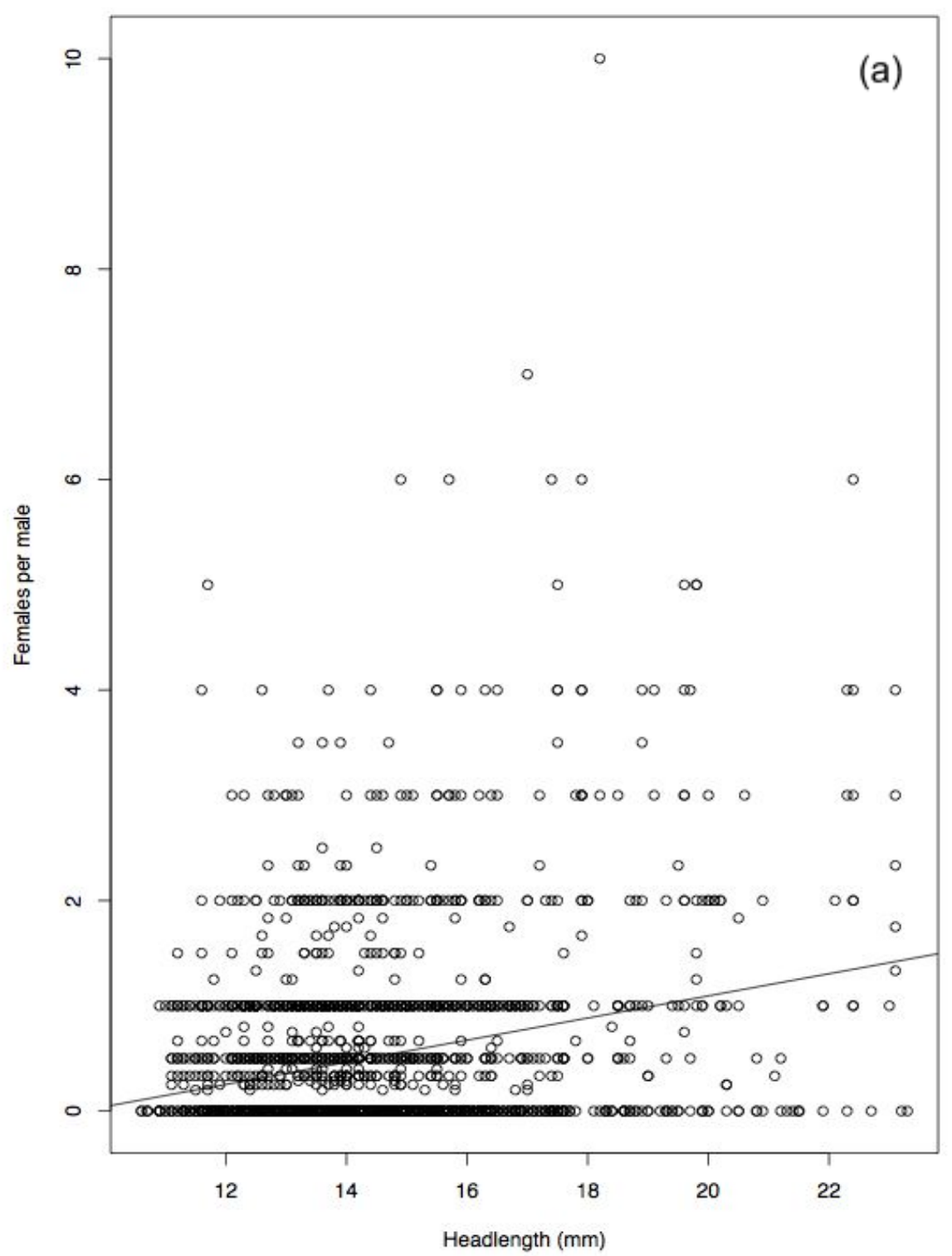




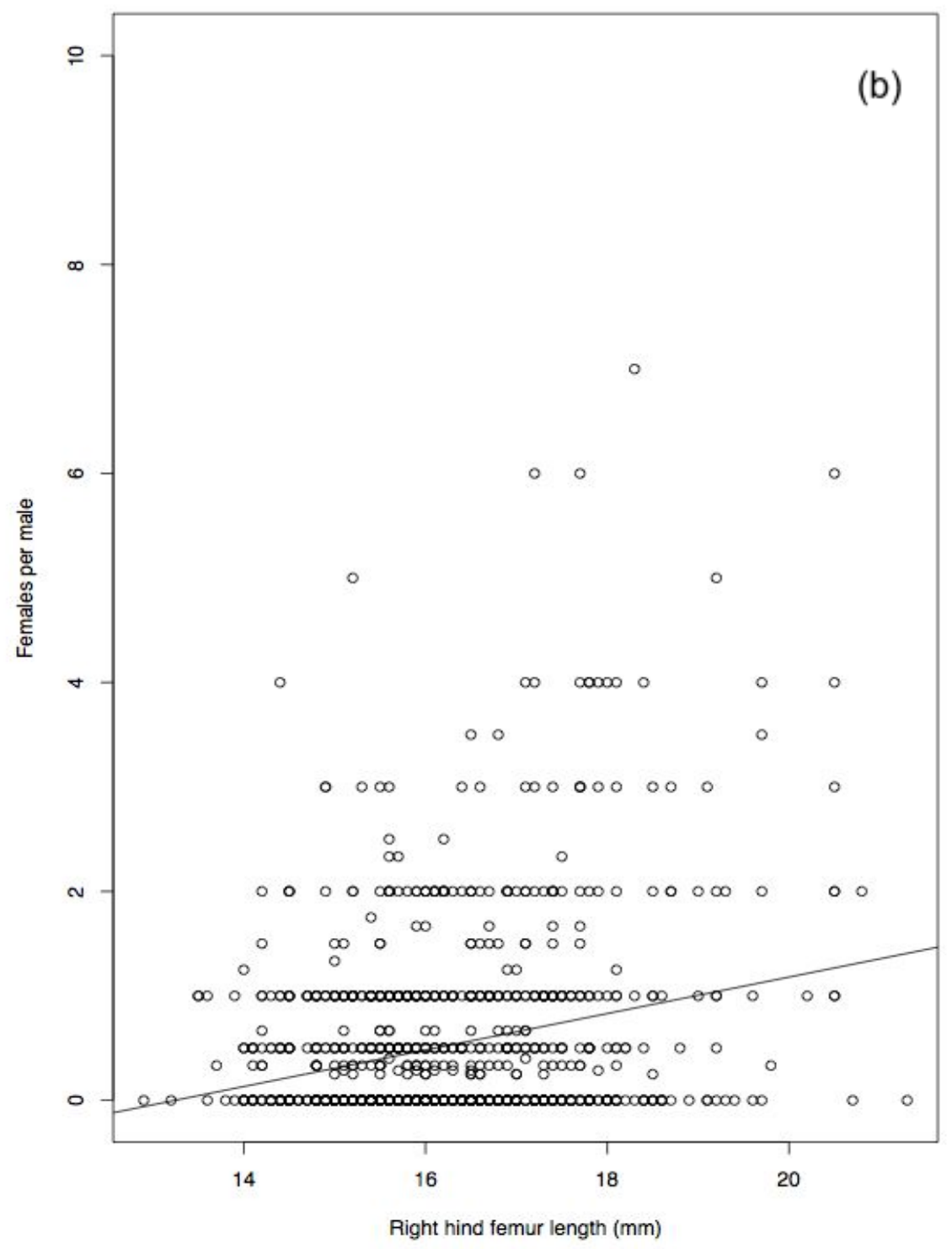

Figure 3.2. Partial regressions showing the relationship between harem size (females per male) and (a) male head length (weapon size), (b) male femur length (body size). 


\subsection{Conclusions and discussion}

\subsubsection{Gallery use by females}

As predicted, the larger galleries contained a higher mean density of females (m) with female found there experiencing and presumably tolerating greater mean crowding $\left(m^{*}\right)$. This pattern of gallery use occurred despite females having the opportunity to distribute themselves across evenly across the large number of small artificial galleries available. Results in this study are consistent with similar field experiments on artificial gallery use by $H$. crassidens (Kelly 2008a, 2006c). In the field experiment, artificial galleries per se were not limiting. However, larger artificial galleries were more limited (20 available per month) while the small artificial galleries were abundant (100 per month) considering the small population size (see chapter 3). It is likely that natural galleries were both small in size and quite limited on Matiu/Somes Island (Kelly 2008a), which is made up of patches of regenerating forest, compared to an old-growth forest with more natural cavities. Natural galleries are likely to be limited on Matiu/Somes Island as the forest is only 25 years old and natural cavities, resulting for example from the larvae of wood-boring beetles (Field and Sandlant 2001), may be more available in older-growth forests. The artificial galleries provided in this experiment probably represented a valuable commodity in an environment where the density of natural galleries is low.

In this experiment on Matiu/Somes Island, the largest harems of females occurred in the presence of a male resident and females did not often crowd together in the absence of a male. Male tree weta are known to aggressively evict females from galleries immediately after copulation and throw them to the ground (Kelly 2008b). It is likely as Kelly (2008a) suggested that the advantage to females of forming harems might come from offsetting the damage that occurs as a result of aggressive male mating behaviours. Perhaps the costs to females resulting from male aggressive mating behaviors (Kelly 2008b) are offset by the presence of other females. It could be that a female choosing to reside in a small gallery was likely to find it occupied by 
an adult male with lesser weapon size who has been unable to gain access to gallery containing a larger number of females.

Contrary to prediction, I did not find any seasonal patterns in harem formation by females. In this study, measurements were made on a monthly basis and as such are difficult to compare to related studies on nightly patterns of gallery use and reproductive behaviour by male and female tree weta (Wehi et al. 2013a; Kelly 2006b). After observing daily patterns of gallery use by a closely related species of tree weta $(H$. thoracica) for over a year Wehi et al. (2013a) found strong seasonal effects on harem formation and movement patterns. Female $H$. thoracica were found to avoid one another until early summer when harems began to form (Wehi et al. 2013a). Kelly's (2006b) field experiment demonstrated that the availability of either large or small artificial galleries influences nightly movement patterns in $H$. crassidens. Although no difference was found between males and females in the number of galleries visited per night, males were found to visit more galleries overall and the effect was greater when only small galleries were available (Kelly 2006b). Long term studies on gallery use in $H$. crassidens over a series of years have focussed on 2-3 months (March-May) per year (Kelly 2008a) and so do not reveal seasonal patterns. Further work is needed to establish whether there might be seasonal effects on harem-forming behaviour in $H$. crassidens. It is important ensure that the description of the tree weta mating system as harem defense polygyny is consistant with the way this term is applied across taxa (Griffin et al. 2019).

\subsubsection{Male weapon size and gallery occupation}

As predicted, males with larger weapons were found in the larger galleries containing a larger number of females. I found that the average weapon size of male residents was significantly smaller in the small artificial galleries and larger in the large artificial galleries on Matiu/Somes Island. In male $H$. crassidens, exaggerated male mandible length is thought to be favored because investment in this trait increases an individual's ability to defend galleries containing the largest harems of females and 
potentially reduce the use of these resources by other males in the population (Kelly 2005a, 2006d, 2008a; Nason 2019). Recent research (Wilson and Kelly 2019) partially supports predictions about alternative reproductive strategies in $H$. crassidens demonstrating that 8th instar males exhibit a behavioural syndrome of "sneaker" mating strategies. Both 9th and 10th instar males seem to shift between sneak and guard behaviours under experimental conditions (Wilson and Kelly 2019). Assuming that a male resident always mates with all the females in a gallery, male who guard bigger galleries containing larger harems can increase their reproductive success (Kelly 2006c, 2008a). However, paternity studies indicate that 8th instar males with reduced weaponry can enjoy a similar level of reproductive success to 9th and 10th instar males with more exaggerated weaponry (Nason 2019).

Sexual selection theory predicts that where resources required for reproduction are scarce, sexual selection on traits that increase fitness in competition for resources will intensify (Emlen and Oring 1977; Shuster \& Wade 2003). Galleries are not required for reproduction, but their availability is likely to be critical in determining the payoffs to males engaging in alternative reproductive strategies. On Matiu/Somes Island, where a high proportion of small galleries are available, the disparity in mating success among males is likely to increase (Wey and Kelly 2018; Kelly 2006b). The snapshots of gallery occupation in this study do not reveal anything about the reproductive success of males with reduced weaponry, but recent work suggests that alternative reproductive strategies in $H$. crassidens result in a similar level of reproductive success (Nason 2019). Small galleries have been linked to shorter occupation times and greater movement based on nightly observation of $H$. crassidens on Maud Island (Kelly 2006b) and also to increased potential for sperm competition (Wey and Kelly 2018).

The presence of multiple males in the same gallery is interesting given the aggressive interactions between rivals over access to galleries (Kelly 2006a). Experiments by Wehi et al. (2017) demonstrated that male tree weta are attracted to chemical signals (cuticular hydrocarbons) left by members of their own species but cannot distinguish between chemical cues left by males and females. This might 
help explain why males are attracted to a gallery containing conspecifics, but why they would not depart upon discovering that it is occupied by another male is unclear. 


\section{Chapter Four:}

\section{Diet has a major effect on growth rate and adult weapon size in male Wellington tree weta.}

\subsection{Introduction}

Foraging strategies of insects determine diet quality which then affects their ability to allocate resources to competing life history traits such as survival, growth and reproduction (Boggs 1992, 2009). Compared to specialist herbivores or carnivores, omnivorous insects potentially have more options available to adjust their nutritional intake and increase their chance of survival in response to a range of environmental conditions (Hassell and Southwood 1978; Coll and Guershon 2002). The Wellington tree weta, Hemideina crassidens (Orthoptera: Tettigonioidea: Anostostomatidae), is a large-bodied, flightless, nocturnal insect endemic to New Zealand (Gibbs 2001). Some environments will present greater abundance of different resources and scarcity of others and it is likely that in the wild $H$. crassidens has a choice between herbivory and omnivory (McIntyre 2001). Studies that examined diet preference of Wellington tree weta in captivity (Wehi et al. 2013b, Griffin 2011, Griffin et al. 2011) and in the field (Dewhurst 2012) indicate that $H$. crassidens is better described as opportunistically omnivorous rather than herbivorous (Griffin et al. 2011; Dewhurst 2012). There is also evidence from studies on nutritional ecology that $H$. crassidens feeds selectively to balance their intake of protein and carbohydrate (Wehi et al. 2013b) and may select leaves with higher lipid content when compared with their close relative the Auckland tree weta (Hemideina thoracica) (Brown 2013). Wellington tree weta have also been shown to engage in cannibalism when reared on a low protein diet (Wehi et al. 2013b). It is possible that specific components of 
diet may have a significant impact on growth rate and adult morphology in insects such as $H$. crassidens (Teder et al. 2014).

Individuals in relatively poor condition as a result of stress, infection or poor nutrition during juvenile development/ontogeny may suffer costs impacting survival and reproduction (Le Gall and Behmer 2014). Individuals may also face a reduction in fitness as a result of a suboptimal diet if they are unable to allocate resources during development to the growth of exaggerated sexually-selected traits such as ornaments or weapons (Hill 2011; Kodric-Brown et al. 2006). Some of the most extreme examples of exaggerated trait growth are found in insect species (reviews of multiple insect orders in: Lavine et al. 2015; Emlen 2008). The growth of these exaggerated secondary sexual traits has been shown, in a range of species, to depend on an individual organism's condition (Andersson 1986, Warren et al. 2013). Populations of $H$. crassidens males reared in the laboratory can reach maturity after eight, nine or ten nymphal instars, with positive covariation between number of instars and weapon size (Spencer 1995). Tree weta are hemimetabolous, meaning they go through a series of instars during development before reaching adulthood, this is unlike development in holometabolous insects in which there is often substantial reorganisation of the body between the larval and pupal stadia. The potential of male Wellington tree weta to attain an adult stage in either the 8th, 9th or 10th instar represents an unusual adult male trimorphism (Kelly and Adams 2010). In one study, females hatched and raised in captivity all went through a uniform ten instars (Spencer 1995). In the field, $H$. crassidens populations show a high level of sexual dimorphism and highly positive allometry in male weapon size (Kelly 2005a). Male weaponry (measured as total length of head capsule and mandibles) plays a significant role in determining the outcome of competition among males for mates and thus influences male reproductive success (Kelly 2005, 2006a, 2006b, 2008).

Here I examine how dietary protein influenced growth rate and final size of adult male weapons as well as the development time measured as the number of days between hatching and maturity. I use allometric scaling to investigate how weapon size (head length) scales against body size (right femur length) in $H$. crassidens. 
Allometry, in its broadest sense, describes the scaling relationship between co-varying biological measurements (Shingleton, 2010). Static allometry describes how the relative size of a trait such as male weaponry changes compared to overall body size in individuals measured at a similar developmental stage (Egset et al., 2011; Gould, 1966). Ontogenetic allometry describes how the relative size of a trait changes compared to body size during the course of development as an individual organism grows (Pélabon et al. 2013; Cheverud, 1982). What a tree weta eats and how it then allocates those resources during development is likely to be critical in determining adult traits such as weapon size.

Here test the following predictions:

1. Males fed a protein supplement will complete juvenile development sooner (reduced development time) than males fed an herbivory only diet consisting primarily of leaves.

2. Males fed a protein supplement will develop greater head length equivalent to adult females at an earlier point in development than males fed an herbivory only diet consisting primarily of leaves.

3. Conversely, males raised on an herbivory only diet will have smaller heads at equivalent juvenile stages and will take longer to reach their adult form (as smaller male morphs) compared to males raised on a protein supplemented diet.

\subsection{Materials and methods:}

\subsubsection{Test subjects and rearing conditions}

Adult female Wellington tree weta $(n=20)$ were collected by G.W. Gibbs in April

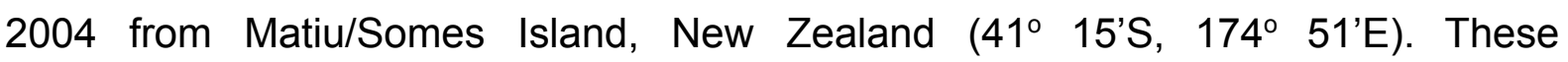
wild-caught females, assumed to be either already gravid or to hold stored sperm from previous matings, were left to oviposit in individual plastic cages (165 x $165 \times$ $85 \mathrm{~mm}$ ) containing $30 \mathrm{~mm}$ of moist local topsoil as an oviposition medium. The cages were provided with a copious supply of leaves of a common tree species 
present on Matiu/Somes Island (Coprosma repens) and slices of fresh carrot. Weta were housed in an open shaded building exposed to ambient light and temperature in Scorching Bay (a coastal region of Wellington approximately $5 \mathrm{~km}$ from Matiu/Somes Island). Unfortunately there was no recording of temperature or humidity conditions in this trial. Food and soil moisture was checked after 7 days and the females removed after 14 days. The undisturbed soil (with food removed) was maintained in these cages over winter (June-August) with checks for moisture levels until the first hatchlings appeared in October 2004, after 26 weeks.

The first instar nymphs were removed to individual plastic food tubs (200 x $85 \mathrm{~mm})$, each provided with a damp filter-paper base, a short length of drinking straw (inside which the nymphs conceal themselves), and a few small holes in the lid. Hatching continued for 4 weeks between $25^{\text {th }}$ October and $21^{\text {st }}$ November 2004, yielding a total of 200 nymphs. A random sample of 100 nymphs (which were unable to be sexed at this instar) was assigned to the experimental treatments, with 50 receiving a purely herbivorous diet of fresh $C$. repens leaves and carrot slice twice weekly, while the other 50 received the same plant diet with the addition of dry fish food (Tetra Fin Plus ${ }^{\circledR}$ : approximately $44 \%$ protein, 12\% fat), as a protein supplement once each week. Unfortunately the exact amount was not recorded. Surplus plant food was available at all times but the fish flakes were provided for one day only and then removed as mould growth could become a problem if the flakes were left on the food for a longer duration. This feeding regime was maintained and increased according to demand throughout their development period until the final moult was reached, identified by the presence of the curved form of male cerci (Stringer \& Cary, 2001).

When nymphs reached their $4^{\text {th }}$ instar (about 13 weeks at summer temperatures), they were sexed by observing the presence or absence of an ovipositor and the females discarded, leaving 25 males in the non-supplement (herbivory) diet treatment and 21 in the protein supplement treatment. Head length and right femur length measurements of individuals were taken at two points during juvenile development and following the molt to adulthood. The total duration (in days) of 
nymphal development was recorded. It was not possible to measure the length of individual instars due to the fragility of the nymphs and the increased mortality that would have likely resulted from repeatedly marking individuals. Morphological measurements of male weapon size (head capsule plus mandible length) and body size (right hind femur length) were made with Vernier dial calipers to the nearest $0.1 \mathrm{~mm}$.

\subsubsection{Data analyses}

To analyse how the protein supplement or herbivory only diet given during juvenile development influences male weapon size we fitted a standardised major axis models using the 'smatr 3' package in R v.3.4.3. ( $R$ Development Core Team, Vienna, Austria; www.Rproject.org). smatr 3 is designed for estimation and inference about allometric lines (Warton et al. 2007, 2011). This package, while targeted at allometric measurements also covers other basic statistical tests such as the Wald statistic for $\mathrm{X}^{2}$ and Welch Two Sample t-test.

\subsection{Results:}

\subsubsection{Development time from hatching to adult in high vs low protein diet treatments}

Of the original 50 male individuals assigned to each diet treatment group (100 in total) a total of 19 individuals in the protein supplement diet condition and 23 individuals in the herbivory diet treatment survived from hatching to maturity (42 in total). The range for days from hatching to adulthood in the herbivory group was 350-447 with a mean of 383 days while the protein supplement group ranged from 242-410 with a mean of 322 days from hatching to adulthood (Figure 4.1). Total number of days between hatching and the final moult to adulthood with high vs low protein diet was analyzed using multivariate analysis of variance (MANOVA). There was a significant difference in total development time between the two treatment groups $\left(F_{2,39}=85.657, P<0.0001\right)$ with individuals in the herbivory only group taking an average of 59 days longer to reach adulthood than individuals in the protein 
supplement group $(\mathrm{t}=4.2129, \mathrm{df}=21.692, P=0.0002$, Figure. 4.1). The protein supplemented diet appears to have allowed individuals to reach the final moult to sexual maturity significantly sooner than individuals who were fed the herbivory only diet throughout juvenile development.

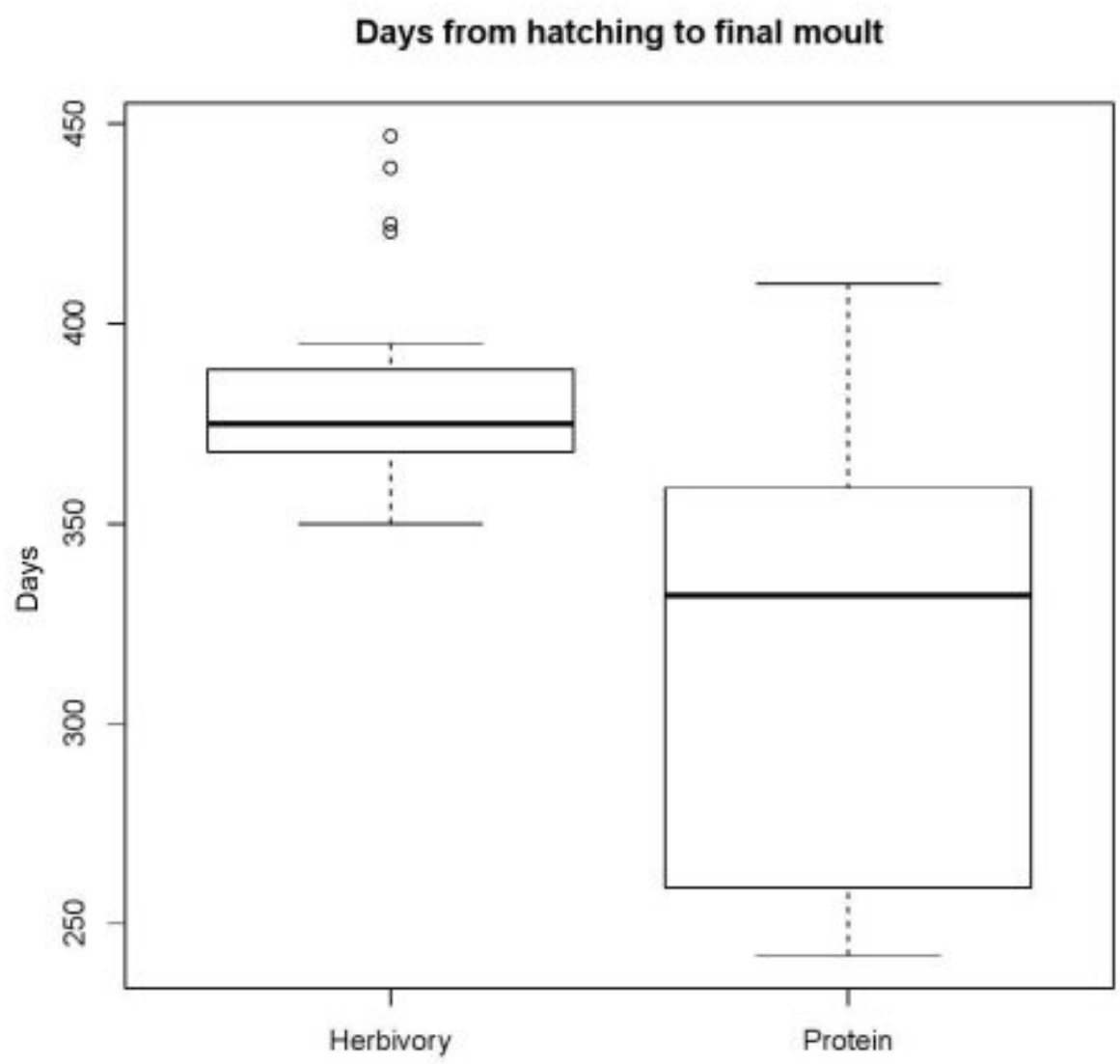

Figure 4.1: Development time from hatching to adult in high vs low protein diet treatments. The components of the boxes are the interquartile range showing the middle $50 \%$ of development times. The whiskers show the upper and lower $25 \%$ of development times with the dots showing outliers in the herbivory treatment.

\subsubsection{Juvenile allometry 1: 128-145 days from hatching}

The results of our model fitting using Standardized Major Axis (SMA) regression show that the allometric slopes $(b)$ were not significantly different between the herbivory treatment $(b=1.430)$ and the protein treatment $(b=1.236)$ (likelihood ratio test, $\left.X^{2}{ }_{1}=0.594, P=0.441\right)$. I also found no difference in elevation between the allometric slopes of the two treatment groups at 128-145 days from hatching $\left(X^{2}{ }_{1}=\right.$ 
$0.450, P<0.502$, Figure 1a). The common allometric slopes with no difference in elevation of slopes between the two diet treatment groups are an indication that individuals at this stage of development made an equivalent investment in growth of head length versus growth in body size. However, I also found strong evidence for a shift along the common axis between the two groups at this earlier stage of development $\left(X^{2}{ }_{1}=113.2, P<0.0001\right)$. The shift along the common axis between two groups at 128-145 days from hatching (Figure 4.2) shows that although investment in head length relative to body length was equivalent in the two diet treatment groups, the individuals that were given a protein supplemented diet had significantly greater head length (mean $=9.97 \mathrm{~mm}$ ) than those in the herbivory group $($ mean $=7.11 \mathrm{~mm})(\mathrm{t}=-11.642, \mathrm{df}=39.794, P<0.0001)$. Individuals in the protein treatment group also had significantly greater right hind femur length (mean $=13.08$ $\mathrm{mm})$ than those in the herbivory group $($ mean $=9.88 \mathrm{~mm})(\mathrm{t}=-13.057, \mathrm{df}=38.338, P$ $<0.0001)$. 


\section{Juveniles 128-145 days from hatching}

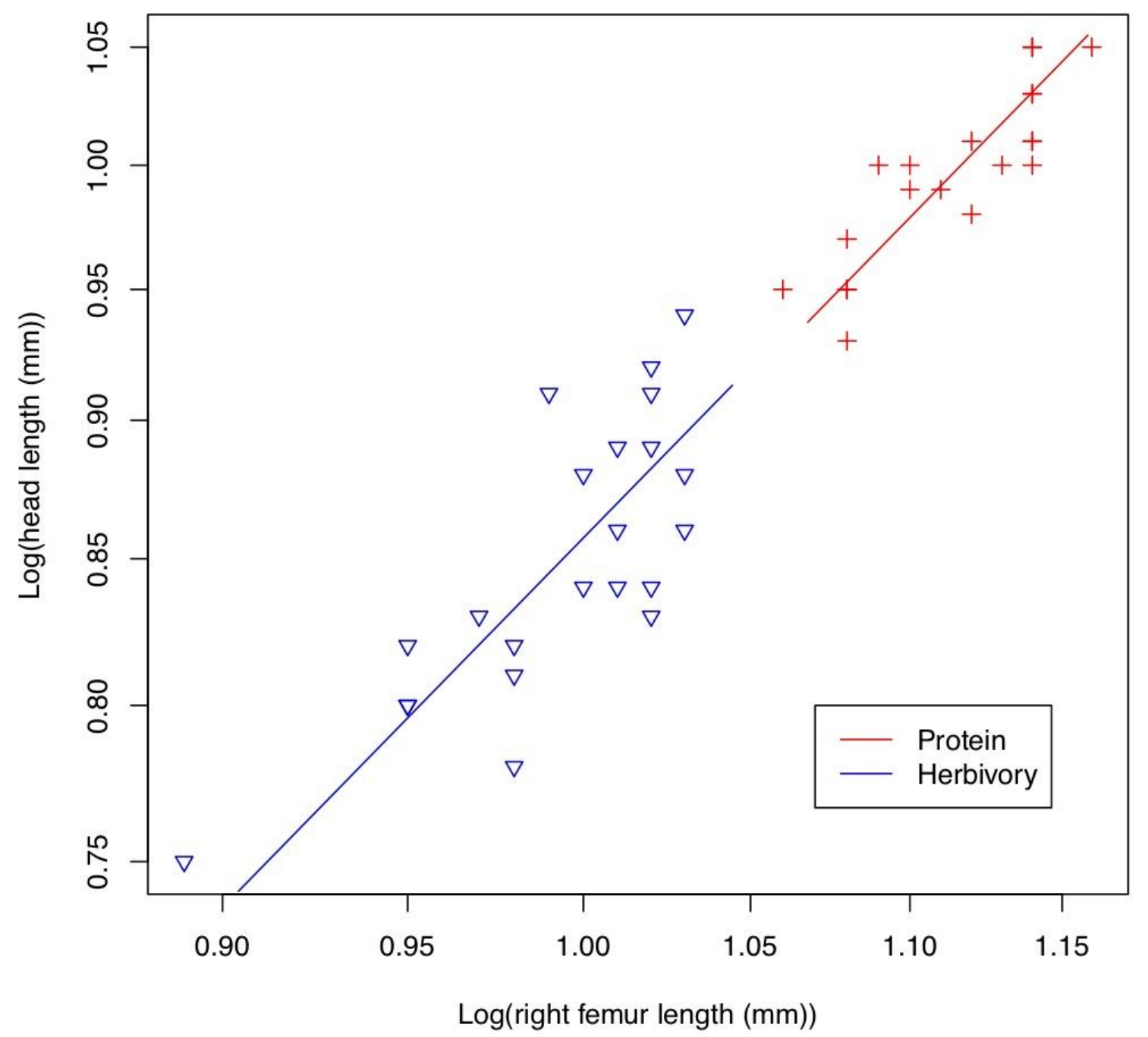

Figure 4.2: Allometric scaling of head length vs right femur length in juveniles 128-145 days from hatching. The slopes are statistically similar $\left(X^{2}{ }_{1}=0.450, P<0.502\right)$ between the two diet treatment groups and the two groups, but show a shift along a common axis.

\subsubsection{Juvenile allometry 2: 219-236 days from hatching}

I again found no evidence to reject the null hypothesis, which stated that the allometric slopes of weapon size scaled against body size would be equal between the herbivory treatment $(b=1.377)$ and the protein treatment $(b=1.35)$ (likelihood ratio test, $X^{2}{ }_{1}=0.018, P=0.893$, Figure. 4.3). In contrast to the first measure of juvenile growth we found a significant difference in the elevation of slopes between the two diet treatment groups at 219-236 days from hatching $\left(X^{2}{ }_{1}=15.02, P=\right.$ 
0.0001. Figure. 4.3). At this point in development, males given protein supplements had greater head length relative to body size than males fed an herbivory only diet.

At this stage of development individuals in the protein treatment group did not differ significantly in head length (mean $=13.02 \mathrm{~mm}$ ) from those in the herbivory group $($ mean $=12.47 \mathrm{~mm})(\mathrm{t}=-1.281, \mathrm{df}=35.585, P=0.209)$. Nor did right hind femur length differ significantly between individuals in the protein group (mean $=15.53 \mathrm{~mm}$ ) and those in the herbivory group $($ mean $=15.61 \mathrm{~mm})(\mathrm{t}=0.185, \mathrm{df}=35.094, P=$ 0.854). Although males fed a protein supplement appeared to be investing more in growth of head length relative to body size than males fed only on leaves, the average head length and body size in the two groups did not differ in contrast again to the earlier juvenile growth stage we measured. 


\section{Juveniles 219-236 days from hatching}

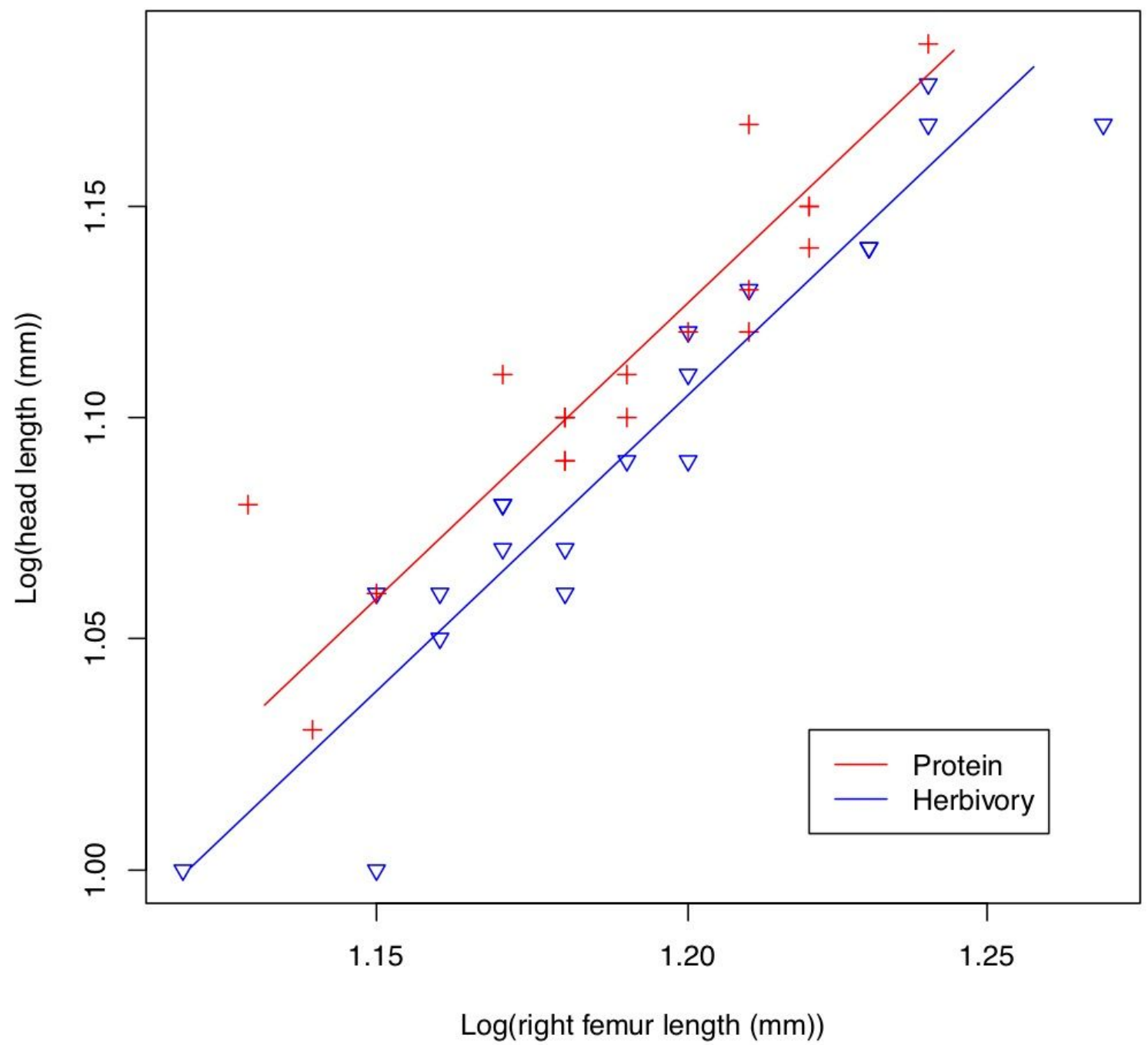

Figure 4.3: Allometric scaling of head length vs right femur length in juveniles 219-236 days from hatching. Although slopes are equal between the two diet treatment groups $\left(X^{2}{ }_{1}=\right.$ $0.018, P=0.893)$ there was a significant difference in elevation $\left(X^{2}{ }_{1}=15.02, P=0.0001\right)$.

\subsubsection{Adult allometry: 250-410 days from hatching (protein treatment group) or} 363-446 days from hatching (herbivory treatment group)

The allometric slopes $(b)$ of the herbivory group $(b=1.722)$ and the high protein group $(b=1.8734)$ were not significantly different (likelihood ratio test, $X^{2}{ }_{1}=0.361, P$ $=0.548)$. We then tested for differences in elevation of allometric slopes between the two diet treatment groups. As with juveniles at 219-236 days from hatching, the 
results of the model fit using SMA regression allow us to reject the null hypothesis and conclude that there is evidence for a difference in elevation between slopes $\left(X^{2}{ }_{1}\right.$ $=32.96, P<0.0001$, Figure. 4.4). As adults, individuals fed additional protein had greater head length relative to body size than did the males in the herbivory only diet treatment (Figure. 4.4).

Examining these traits separately; individuals in the protein treatment group had significantly greater head length (mean $=19.37 \mathrm{~mm}$ ) than those in the herbivory group $($ mean $=16.70 \mathrm{~mm})(\mathrm{t}=-3.5748, \mathrm{df}=39.896, P<0.001)$. Individuals in the protein treatment group also had significantly greater right hind femur length (mean = $18.14 \mathrm{~mm}$ ) than those in the herbivory group $($ mean $=17.71 \mathrm{~mm})(\mathrm{t}=-1.0508, \mathrm{df}=$ 39.984, $P=0.2997)$. 
Adults

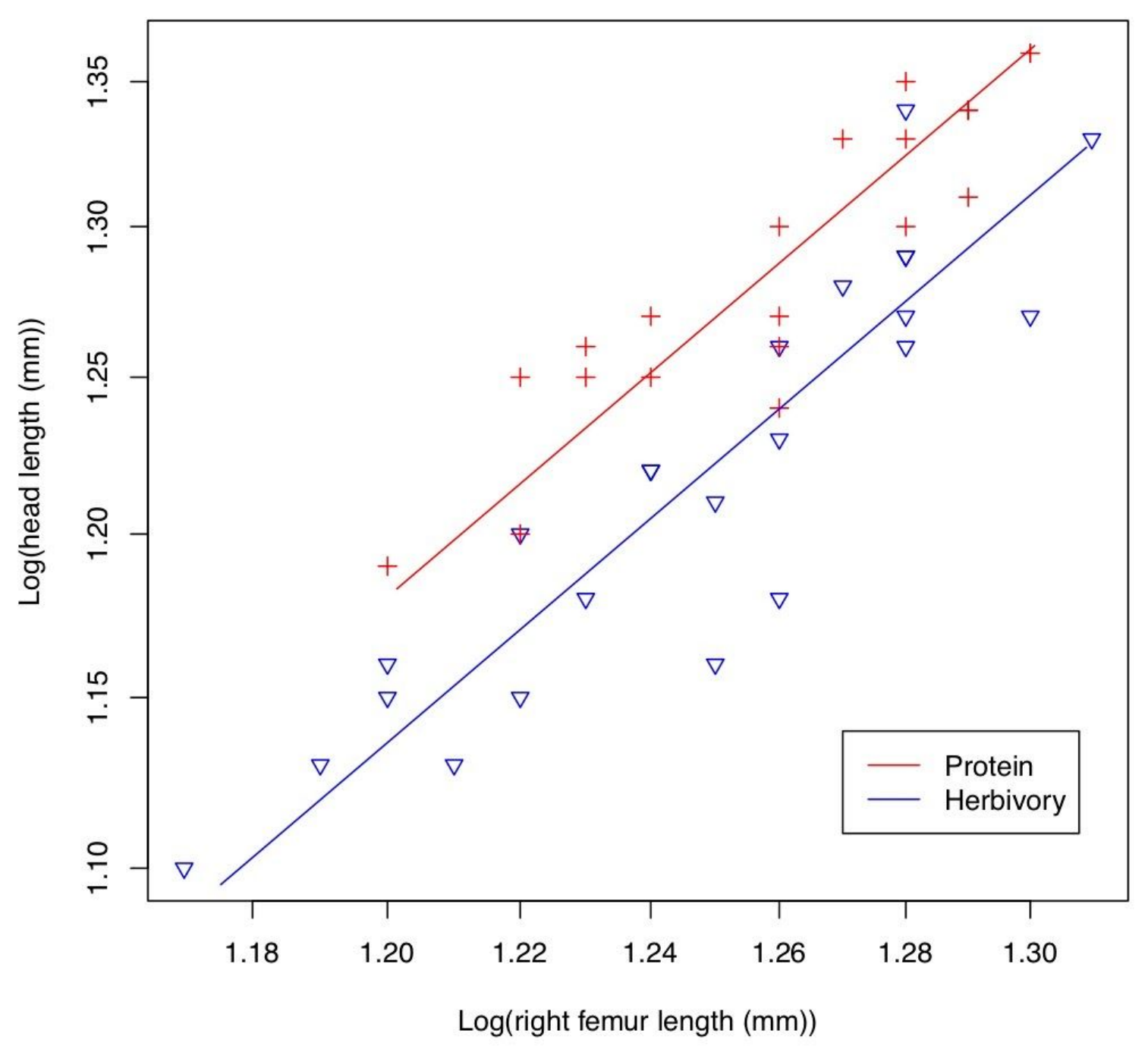

Figure 4.4: Allometric scaling of head length vs right femur length in adults 250-410 days from hatching (protein treatment group) or 363-446 days from hatching (herbivory treatment group). The slopes are equal between the two diet treatment groups $\left(X^{2}{ }_{1}=0.361, P=0.548\right)$ and there is a significant difference in elevation $\left(X^{2}{ }_{1}=32.96, P<0.0001\right)$. 
Table 4.1 Mean +/- SE, range and CV of head length $(\mathrm{mm})$ and femur length $(\mathrm{mm})$ in male Hemideina crassidens during two points in juvenile development and as adults.

\begin{tabular}{|c|c|c|c|c|c|c|c|c|c|}
\hline & & \multicolumn{4}{|c|}{ Protein } & \multicolumn{4}{|c|}{ Herbivory } \\
\hline & & $\begin{array}{l}\text { Mean } \\
(\mathrm{mm})\end{array}$ & $\begin{array}{l}+/- \\
\text { SE }\end{array}$ & $\begin{array}{l}\text { Range } \\
(\mathrm{mm})\end{array}$ & $\begin{array}{l}\text { CV } \\
(\%)\end{array}$ & $\begin{array}{c}\text { Mean } \\
(\mathrm{mm})\end{array}$ & $\begin{array}{l}+/- \\
\text { SE }\end{array}$ & $\begin{array}{c}\text { Range } \\
(\mathrm{mm})\end{array}$ & $\begin{array}{l}\text { CV } \\
(\%)\end{array}$ \\
\hline \multirow{2}{*}{$\begin{array}{c}128-145 \\
\text { days }\end{array}$} & $\begin{array}{l}\text { Head } \\
\text { length }\end{array}$ & 9.94 & 0.18 & 8.5-11.3 & 7.99 & 7.11 & 0.16 & $5.6-8.3$ & 10.14 \\
\hline & $\begin{array}{l}\text { Femur } \\
\text { length }\end{array}$ & 13.03 & 0.19 & $12-13.9$ & 6.38 & 9.90 & 0.17 & 7.7-10.7 & 7.65 \\
\hline \multirow{2}{*}{$\begin{array}{c}219-236 \\
\text { days }\end{array}$} & $\begin{array}{l}\text { Head } \\
\text { length }\end{array}$ & 13.16 & 0.25 & $11.4-14.8$ & 7.96 & 9.03 & 0.25 & $6.5-10.9$ & 13.10 \\
\hline & $\begin{array}{l}\text { Femur } \\
\text { length }\end{array}$ & 15.52 & 0.25 & $13.7-16.6$ & 6.76 & 12.50 & 0.33 & $9.3-14.9$ & 12.66 \\
\hline \multirow{2}{*}{$\begin{array}{c}250-410 \\
\text { days } \\
\text { (Adults) }\end{array}$} & $\begin{array}{l}\text { Head } \\
\text { length }\end{array}$ & 19.37 & 0.52 & $15.7-20.3$ & 11.62 & 16.70 & 0.54 & $12.5-21.9$ & 15.59 \\
\hline & $\begin{array}{l}\text { Femur } \\
\text { length }\end{array}$ & 18.14 & 0.28 & $16.5-19.5$ & 6.72 & 17.71 & 0.30 & $14.9-20.2$ & 8.21 \\
\hline
\end{tabular}

\subsubsection{Growth curves and growth rate}

I tested a series of different curves fitted to the data for head length and right femur length separately (Figure. 4.5). I fitted different empirical polynomial models (linear and quadratic) and found that strong support for the quadratic model with the herbivory data while the protein data was well fitted using a straight line. Both the AIC method and the likelihood ratio test method supported my choice of model. I also fitted a quadratic curve to the ratio of log head length to log right hind femur length vs days from hatching (Figure. 4.6). It took less time for individuals fed a protein supplement to reach adulthood with a greater head length and body size (figure 4.6) than individuals fed an herbivory only diet. Individual males fed a solely herbivorous diet tended to have a negative slope between the two juvenile stages in the ratio of head length to body size while the individual males in the high protein diet treatment had a positive slope between the same points (Figure 4.6). The change in the ratio between head length and femur length between equivalent juvenile stages 
suggests that all males fed a high protein diet invested more in head length relative to body length between these two stages. During a similar stage of development, the majority of males fed an herbivory only diet appear to have invested less in head length relative to body size. Individuals in both diet treatment groups invested more in head length relative to femur length between the second juvenile stage measurement and the molt to adulthood but this took significantly longer for the individuals in the herbivory only group.

\section{Head Length Growth (quadratic)}

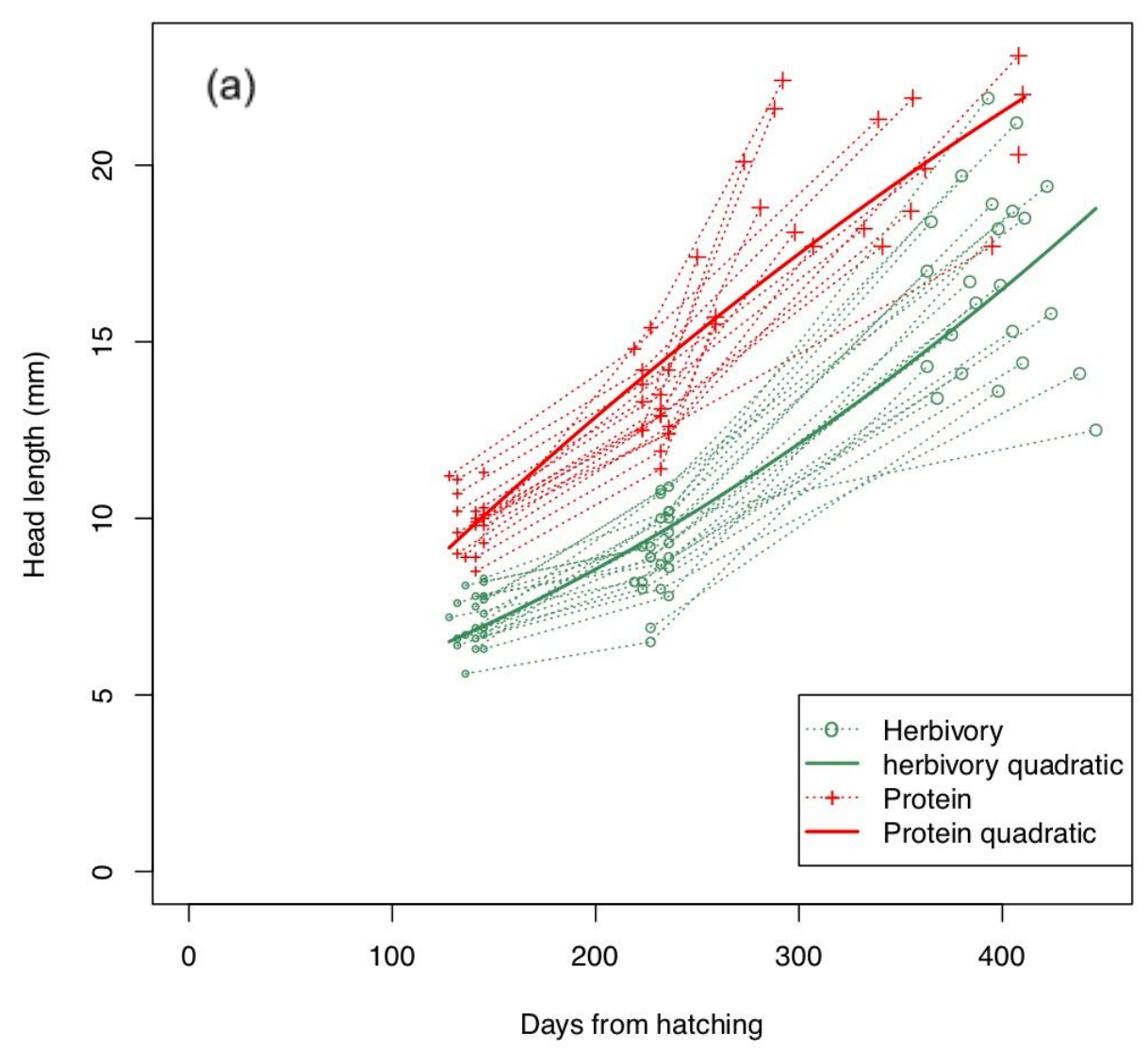


Femur Length Growth (quadratic, non-parallel)

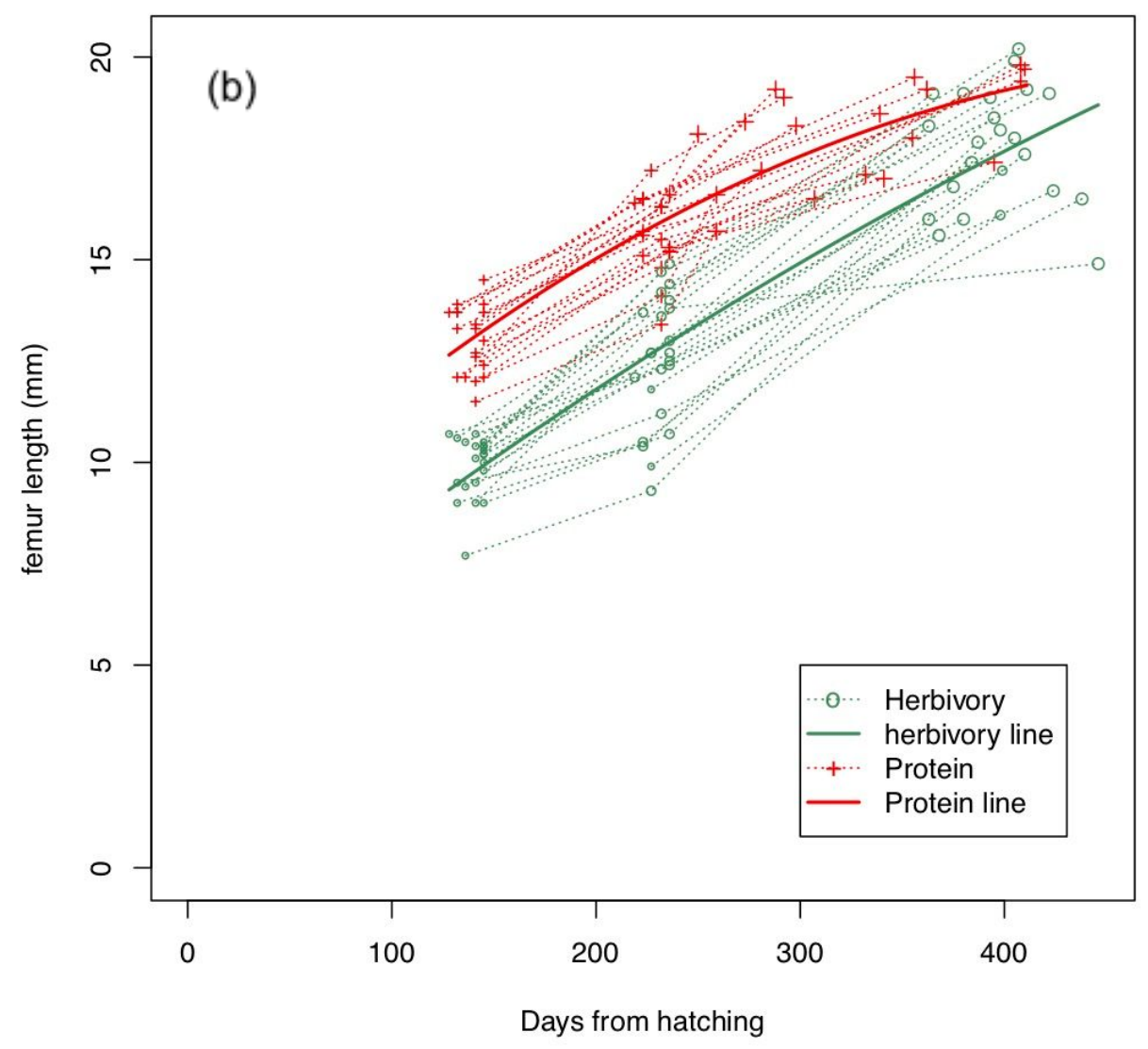

Figure 4.5 Growth curve showing the change in head length (above) and the change in right hind femur length (below) between hatching and adulthood. 


\section{Log HL/RHF Growth (quadratic, non-parallel)}

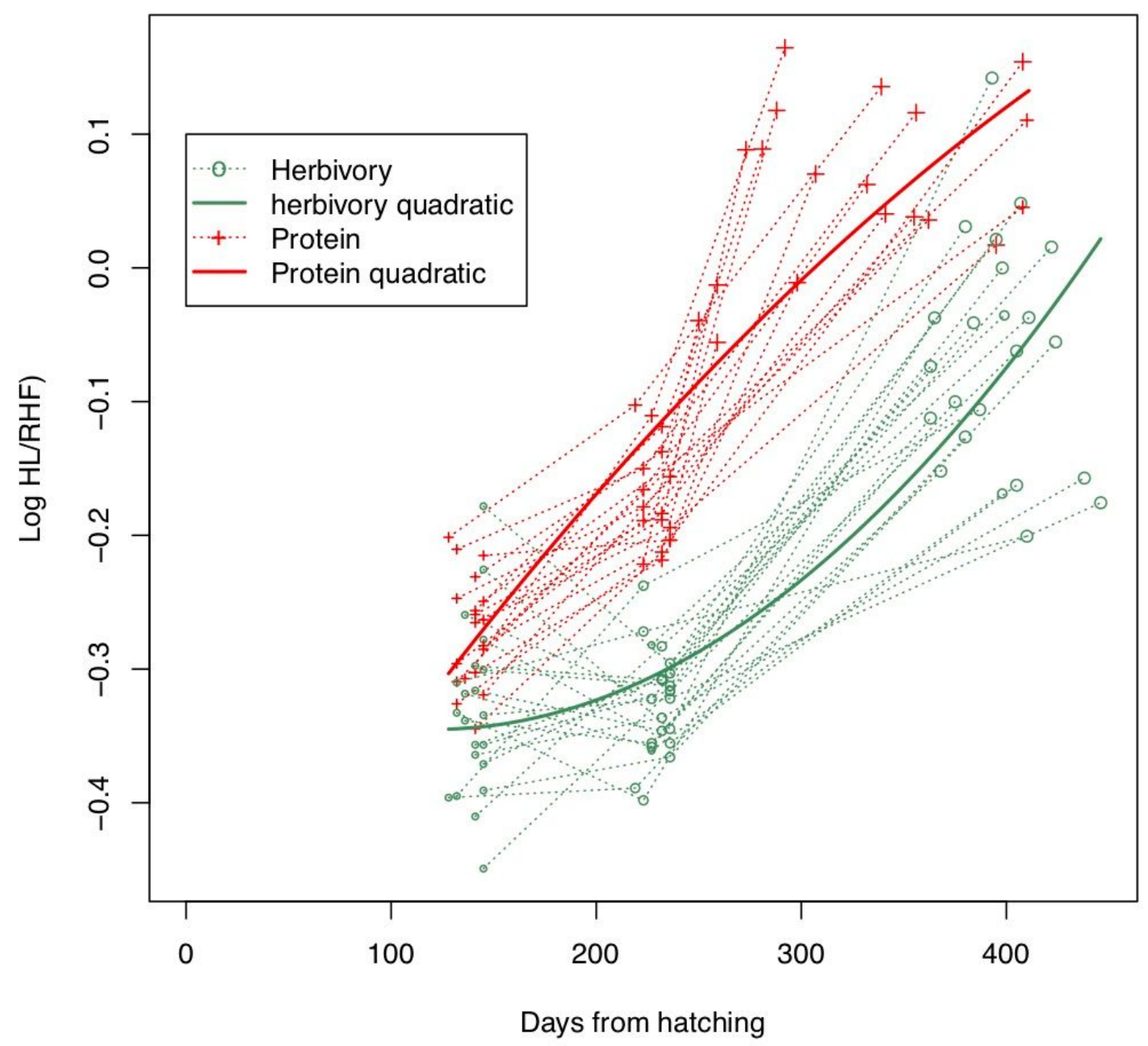

Figure 4.6: Growth curve showing comparison in the changing ratio of head length : femur length in the two diet treatment groups.

Spencer (1995) carried out a discriminant analysis of her data on Wellington tree weta development to determine characters most useful for establishing instars and found head length and femur length were the most important followed by body weight. Unfortunately, Spencer's criteria for distinguishing the 6th and 7th male instar requires a measurement of body weight, which we do not have for this study. I was able to use Spencer's criteria to assign estimates of instars to males for the 5th, 8th, 9th and 10th instars but could only estimate 6th-7th instar in other cases (Table 4.2). While it is unusual to include individual replicates in a main results section I have presented them in Table 4.2. Growth stages appear to be much more similar 
between the two diet treatment groups at 128-145 days from hatching than they were at 219-236 days from hatching (Table 4.2). At the first juvenile measurement only a single individual in the herbivory treatment remained at or below the 5th instar as determined by Spencer's (1995) guidelines (Appendix C). By the second measurement of juveniles, all of the individuals in the protein group were judged to have reached the 8th or 9th instar while none of the individuals in the herbivory group had gone past the 7 th instar (Table 4.2). It is also notable that between the second juvenile measurement and the molt to adulthood all adults in the protein diet treatment went through one more instar (Table 4.2). 
Table 4.2 Estimates of male instar at 3 growth stages based on guidelines from Spencer (1995). Individuals are organised into groups of 10th, 9th and 8th instar adults and by longest duration of development from hatching to maturity within each group.

\begin{tabular}{|c|c|c|c|c|c|c|c|c|}
\hline \multirow[b]{3}{*}{ Weta \# } & \multirow{2}{*}{\multicolumn{2}{|c|}{$\begin{array}{l}\text { Juveniles } 1 \\
\text { 128-145 days } \\
\text { from hatching }\end{array}$}} & \multirow{2}{*}{\multicolumn{2}{|c|}{$\begin{array}{c}\text { Juveniles } 2 \\
\begin{array}{c}\text { 219-236 days from } \\
\text { hatching }\end{array}\end{array}$}} & \multicolumn{2}{|c|}{ Adults } & \multicolumn{2}{|c|}{$\begin{array}{l}\text { Total days from } \\
\text { hatching to maturity }\end{array}$} \\
\hline & & & & & \multirow{2}{*}{\begin{tabular}{|c|}
$\begin{array}{c}363-446 \\
\text { days from } \\
\text { hatching }\end{array}$ \\
$\begin{array}{c}\text { Instar, } \\
\text { herbivory } \\
\text { diet }\end{array}$ \\
\end{tabular}} & \multirow{2}{*}{$\begin{array}{c}\begin{array}{c}250-410 \\
\text { days } \\
\text { from } \\
\text { hatching }\end{array} \\
\begin{array}{c}\text { Instar, } \\
\text { protein } \\
\text { diet }\end{array}\end{array}$} & \multirow{2}{*}{$\begin{array}{l}\text { Days, } \\
\text { Herbivory } \\
\text { diet }\end{array}$} & \multirow{2}{*}{$\begin{array}{l}\text { Days, } \\
\text { Protein } \\
\text { diet }\end{array}$} \\
\hline & $\begin{array}{l}\text { Instar, } \\
\text { herbivory } \\
\text { diet }\end{array}$ & $\begin{array}{c}\text { Instar, } \\
\text { protein } \\
\text { diet }\end{array}$ & $\begin{array}{l}\text { Instar, } \\
\text { herbivory } \\
\text { diet }\end{array}$ & $\begin{array}{l}\text { Instar, } \\
\text { protein } \\
\text { diet }\end{array}$ & & & & \\
\hline 1 & $6-7$ & 8 & $6-7$ & 9 & 10 & 10 & 425 & 362 \\
\hline 2 & $6-7$ & 8 & $6-7$ & 9 & 10 & 10 & 423 & 356 \\
\hline 3 & $6-7$ & 8 & $6-7$ & 9 & 10 & 10 & 393 & 339 \\
\hline 4 & $6-7$ & $6-7$ & $6-7$ & 9 & 10 & 10 & 380 & 292 \\
\hline 5 & $6-7$ & $6-7$ & $6-7$ & 9 & 10 & 10 & 377 & 258 \\
\hline 6 & $6-7$ & 8 & $6-7$ & 9 & 10 & 10 & 375 & 242 \\
\hline 7 & $6-7$ & 8 & $6-7$ & 8 & 9 & 9 & 395 & 410 \\
\hline 8 & $6-7$ & 8 & $6-7$ & 8 & 9 & 9 & 384 & 408 \\
\hline 9 & $6-7$ & $6-7$ & $6-7$ & 8 & 9 & 9 & 381 & 408 \\
\hline 10 & $6-7$ & $6-7$ & $6-7$ & 8 & 9 & 9 & 379 & 395 \\
\hline 11 & $6-7$ & $6-7$ & $6-7$ & 8 & 9 & 9 & 375 & 355 \\
\hline 12 & $6-7$ & $6-7$ & $6-7$ & 8 & 9 & 9 & 375 & 341 \\
\hline 13 & $6-7$ & 8 & $6-7$ & 8 & 9 & 9 & 369 & 332 \\
\hline 14 & $6-7$ & $6-7$ & $6-7$ & 8 & 9 & 9 & 368 & 307 \\
\hline 15 & $6-7$ & $6-7$ & $6-7$ & 8 & 9 & 9 & 368 & 298 \\
\hline 16 & $6-7$ & $6-7$ & $6-7$ & 8 & 9 & 9 & 365 & 259 \\
\hline 17 & $6-7$ & $6-7$ & $6-7$ & 8 & 9 & 9 & 363 & 259 \\
\hline 18 & $6-7$ & $6-7$ & $6-7$ & 8 & 9 & 9 & 363 & 250 \\
\hline 19 & $6-7$ & $6-7$ & $6-7$ & 8 & 9 & 9 & 357 & 250 \\
\hline 20 & $6-7$ & & $6-7$ & & 9 & & 350 & \\
\hline 21 & $6-7$ & & $6-7$ & & 8 & & 447 & \\
\hline 22 & $6-7$ & & $6-7$ & & 8 & & 439 & \\
\hline 23 & $6-7$ & & $6-7$ & & 8 & & 368 & \\
\hline
\end{tabular}




\subsection{Conclusions and discussion.}

\subsubsection{Protein supplemented diet was linked to reduced development time and larger adult weapon size}

This is currently the only study to examine the effect of a protein supplemented diet on the development of male weaponry in Hemideina crassidens. This study also provides information about juvenile development time and growth rate of head length and body size not available elsewhere in the literature. Development time refers to "...the time it takes for an insect to develop through a life stage or life cycle..." (Yurk 2020) while growth rate refers to the increase in a measurement of a trait over time. As predicted, males raised on a purely herbivorous diet had a significantly longer development time from hatching to their final moult compared to males given a protein supplemented diet that had a significantly shorter development time. The total number of instars and the duration of each instar are important determinants of adult size across a range of insect orders (multiple orders reviewed in: Esperk et al. 2007; Chown and Nicolson 2004). Unfortunately, it was not possible to obtain data on the length of specific instars for individuals during the present study because of the increased mortality that results from handling nymphs (G.W. Gibbs, pers. comm). Many life history models assume that there is an optimal growth rate for species faced with time constraints such as seasonal environmental conditions or availability of mates and that as a result shorter development time leads to small adult size (Roff 1986; Stearns 2000).

The results of the present study indicate that growth rates are not constant within male Wellington tree weta and that the time taken to develop from hatching to adulthood is greatly lengthened as a result of a diet lacking in protein. Although the present study does not include data on female development, Griffin (2011) found that female $H$. crassidens that were fed a protein supplemented diet also had a faster growth rate and a shorter development time than those fed an herbivorous diet when measured from the 6/7th instar to adulthood. Temperature is likely to be another major influence influencing growth rate in Tree weta (Minnards 2011). Minnards et al. 
(2014) carried out experiments using $H$. crassidens and $H$. thoracica taken from high and low altitude populations that revealed temperature and collection location had a significant effect on growth rate from the 8th to 10th instar. Both species developed faster at $14^{\circ} \mathrm{C}$ compared to $9^{\circ} \mathrm{C}$ but those from high altitude populations had a growth rate double that of low altitude populations when reared at $14^{\circ} \mathrm{C}$ (Minnards et al. 2014). The subjects in the present study were reared under ambient temperature conditions in a coastal area a few kilometers from Matiu/Somes Island. Although a precise record of the temperature was not kept, it is likely that seasonal temperature changes in the course of this experiment would have been similar to those experienced on Matiu/Somes Island (see chapter 2).

\subsubsection{Male Wellington tree weta reared on a protein supplemented diet invested more in weapon size vs body size earlier in development and had an increased growth rate.}

As predicted, males given a protein supplement in their diet throughout development developed greater head length at both juvenile stages and larger weaponry as adults than did males hatched from the same clutch of eggs and raised on an herbivory only diet. Allometric slopes were positive at both points measured during juvenile development indicating that males in both diet treatment conditions invested disproportionately in growth of head length for weaponry compared to overall body size from approximately the 5th instar onwards. Wehi et al. (2013b) proposed that as sexual dimorphism in head length is not apparent until after the 5th instar in $H$. crassidens, late sub-adult males may have different nutritional needs based on the costs of developing large mandibles. In the present experiment the positive value for all allometric slopes increased at each stage from the 6th instar onwards (table 4.2) suggesting that the investment in weapon size became greater relative to body size during the course of development. Further investigation is needed into the effects of changes to diet during critical instars on adult phenotypes in tree weta.

Males fed a high protein diet invested more in head length relative to body length between these two points measured in juvenile development and the majority of 
males fed an herbivory only diet invested less in head length relative to body size over the same period. This is seen in the change in the ratio between head length and femur length for each diet treatment group between the first (128-145 days from hatching) and second (219-236 days from hatching) (Figure 4.4). This suggests that the individuals with access to more protein were able to allocate these extra nutritional resources early in development to early investment in greater adult weapon size as well as increasing their growth rate. Both diet treatment groups invested more in head length relative to femur length between the second juvenile stage measurement and the molt to adulthood but this took significantly longer for the individuals in the herbivory only group (Figure 4.4). This result raises questions about a potential mechanism in tree weta to overcome the effects of sub-optimal diet by changing their growth rate.

\subsubsection{Males in both diet treatments reached the average adult female head length 219-236 days after hatching.}

Kelly and Adams (2010) proposed that male $H$. crassidens are able to invest in exaggerated weaponry without going through additional instars while females do not and to do so because they "...have evolved a significantly faster, or accelerated developmental rate, allowing them to 'pass through' the female condition at an earlier developmental stage". Female Wellington tree weta do not use their mandibles as weapons and as a result it is natural selection related to acquiring and processing food that determines the combined length of head capsule and mandibles in females (Field and Deans 2001; Kelly and Adams 2010) rather than sexual selection as in males (Kelly 2005a). When fed a protein supplemented diet between the $6 / 7$ th and 10th instar, female $H$. crassidens did not produce a greater number of eggs or more viable eggs compared to females fed a less protein rich diet but did increase their store of fat bodies (Griffin 2011).

Data collected from on Matiu/Somes Island from June 2000-December 2006 (table 4.3) shows an average adult female head length of $11.37 \mathrm{~mm}$ with a range of 9.4 $14.8 \mathrm{~mm}$ based on a sample of 540 individuals. Individuals in both diet treatment 
groups had passed the average head length expected for adult females by 219-236 days from hatching, with head length of $13.03 \mathrm{~mm}$ in the protein supplement group and $12.47 \mathrm{~mm}$ in the herbivory group. Kelly (2005a) gives the average head length for adult females on Maud Island as $13.04 \mathrm{~mm}$ with a range of $10.78-15.91 \mathrm{~mm}$ based on a sample of 386 individuals (Table 4.3). The average adult male head length and body size was also greater than on Maud Island than Matiu/Somes Island. Notably, the largest males were measured on Mana Island, which was the source of the Matiu/Somes founder population (Watts et al. 2008; Table 4.3). Further work is needed to test Kelly and Adam's proposal that ontogenetic acceleration explains the growth of exaggerated male weaponry in male $\mathrm{H}$. crassidens.

Table 4.3. Values for head length (HL) and right hind-femur length (FL) in millimeters for three island populations of Wellington tree weta: Matiu/Somes Island, Mana Island and Maud Island.

\begin{tabular}{|c|c|c|c|c|c|c|c|c|}
\hline & & $n$ & & Mean & Minimum & Maximum & Range & $\pm S E$ \\
\hline \multirow{4}{*}{$\begin{array}{l}\text { Matiu/Somes } \\
\text { Island *1 }\end{array}$} & male & 1088 & $\mathrm{HL}$ & 14.29 & 10.7 & 22.5 & 11.8 & 0.13 \\
\hline & male & 1088 & FL & 16.15 & 12.9 & 21.3 & 8.4 & 0.08 \\
\hline & female & 540 & HL & 11.37 & 9.4 & 14.8 & 5.4 & 0.04 \\
\hline & female & 540 & $\mathrm{FL}$ & 19.10 & 15.7 & 23.3 & 7.6 & 0.05 \\
\hline \multirow{4}{*}{$\begin{array}{l}\text { Mana } \\
\text { Island *2 }\end{array}$} & male & 147 & $\mathrm{HL}$ & 18.99 & 13.9 & 27.6 & 13.7 & 0.26 \\
\hline & male & 100 & FL & 18.67 & 16.2 & 21.9 & 5.7 & 0.13 \\
\hline & female & 100 & $\mathrm{HL}$ & 12.67 & 10.2 & 14 & 3.8 & 0.07 \\
\hline & female & 100 & $\mathrm{FL}$ & 21.18 & 18.4 & 23.1 & 4.7 & 0.1 \\
\hline \multirow{4}{*}{$\begin{array}{l}\text { Maud } \\
\text { Island }^{*}\end{array}$} & male & 359 & $\mathrm{HL}$ & 20.88 & 12.76 & 31.72 & 18.96 & 0.24 \\
\hline & male & 359 & $\mathrm{FL}$ & 18.47 & 14.91 & 22.62 & 7.71 & 0.09 \\
\hline & female & 386 & $\mathrm{HL}$ & 13.04 & 10.78 & 15.91 & 5.13 & 0.05 \\
\hline & female & 385 & FL & 20.83 & 17.00 & 23.82 & 6.82 & 0.07 \\
\hline
\end{tabular}

*1 Data from Matiu/Somes Island collected 2000-2006 by G.W. Gibbs and A.S Dixson

*2 Data from Mana Island collected 2002-2003 by G.W. Gibbs

*3 Data from Maud Island taken from Kelly (2005a). 


\section{Chapter 5: Summary and future directions}

\subsection{Summary of results.}

\section{Chapter Two: Survivorship and Seasonal patterns in Wellington Tree Weta on Matiu/Somes Island.}

During the 42 months of the mark recapture study on Matiu/Somes Island, males had a longer adult mean minimum lifespan and a higher frequency of individuals that lived 8 months or more. and the oldest recaptured individual. The maximum recorded age of males (12 months) was also greater than that of females (10 months). These results indicate that males on Matiu/Somes Island are frequently capable of outliving females. There was no significant difference in mean minimum lifespan between males reaching adulthood after an estimated eight, nine or ten juvenile instars. Further analysis of head length as a covariate with survival revealed that males with larger weaponry had higher survivorship than males with reduced weaponry.

Season was also an important factor in modelling the survival and recapture probabilities of male and female Wellington tree weta. The largest numbers of newly-marked adult males and females were recorded between December and May in each of the three years. Patterns of the appearance of newly marked adult males and females indicate that there may be a seasonal aspect to mating in $\mathrm{H}$. crassidens on Matiu/Somes Island. I hypothesised that egg laying on Matiu/Somes is likely to be concentrated in autumn as the average temperature is decreasing (March-May) and eggs may then enter embryonic diapause, but this suggestion requires further investigation. 


\section{Chapter Three: Use of artificial galleries by females and selection for exaggerated male weaponry in Wellington tree weta on Matiu/Somes Island.}

Although females had the opportunity to distribute themselves across evenly across the large number of small artificial galleries available, they were found more often in aggregations in larger galleries. The larger galleries contained a more females (higher mean density) on average that smaller galleries. Females also experienced greater mean crowding $\left(\mathrm{m}^{*}\right)$ or a higher 'mean number per individual of other individuals' in the larger galleries. On Matiu/Somes Island, the largest harems of females occurred when a male was also present. Few crowded aggregations of females were recorded without a male also also being a resident in the same gallery. Based on monthly observations, I did not find any seasonal patterns in harem formation by females.

I found a positive relationship between weapon size and harem size on Matiu/Somes Island. Males with larger weapons were found in the larger galleries containing the larger number of females. The average male weapon size in the small artificial galleries was also significantly less than that of males in the large artificial galleries. Kelly (2008a) suggested tree weta on Matiu/Somes Island may have smaller average weapon size compared to Maud Island as a result of smaller natural gallery sizes on Matiu/Somes acting as a selective pressure on exaggerated weaponry. I found some support for this suggestion based on average male weapon size on Matiu/Somes Island and a comparison of adult male head lengths across Islands.

Chapter Four: Diet has a major effect on growth rate and adult weapon size in the Wellington tree weta, Hemideina crassidens.

Male Wellington tree weta whose diet was restricted to taupata leaves and carrot took significantly longer to reach maturity than did males from the same clutch of eggs that were given a protein supplement in their diet. The first point at which nymphs were measured was 128-145 days from hatching and the second 
measurement was made at 219-236 days from hatching. The allometric slope, showing the scaling relationship between weapon size and body size, changed throughout development. However, allometric scaling of these traits showed a common allometric slope for each diet treatment when head length and femur length were measured after 128-145 days and again after 219-236 days.

Males in both diet treatment conditions invested disproportionately in growth of head length for weaponry compared to overall body size from approximately the 5th instar onwards. Dividing head length by body size gave a ratio that could be used to measure the investment in head size and body size between each point where weta were measured. Between 128-145 and 219-236 days, males fed a high protein diet invested more in head length relative to body length than did the majority of males fed an herbivory only diet. Most, but not all, males in the herbivory only diet treatment invested less in head length relative to body size between 128-145 and 219-236 days. All individuals in both diet treatment groups invested more in growth of head length than femur length between 219-236 days and the point they reached maturity.

Measurements collected on Matiu/Somes Island in the years immediately before and after this experiment took place give $11.37 \mathrm{~mm}$ as the average head length recorded for adult females. When measured 219-236 days after hatching the average head length of males was $13.03 \mathrm{~mm}$ in the protein supplement group and $12.47 \mathrm{~mm}$ in the herbivory-only group. Males in both had generally passed the average adult female head length after 219-236 days of development. The range of development time from hatching to maturity was 350-447 days, with a mean of 383 days in the herbivory diet treatment group. In the protein supplement group, this range was 242-410 days with a mean of 322 days. A comparison of adult male and female measurements on Matiu/Somes Island, Maud Island and Mana Island shows that on average Matiu/Somes had the smallest adults. 


\subsection{Discussion and future directions}

In order to further investigate possible seasonal variation in female harem-forming behaviour, studies of nightly patterns of gallery use by $\mathrm{H}$. crassidens over one to two years is needed. Existing studies of gallery use patterns by $H$. crassidens show nightly patterns of movement and gallery occupation by females over three months of each year (Kelly 2006b). Further studies would be useful to investigate whether $H$. crassiden's harem-forming behaviour is limited to specific seasons as observed in $H$. thoracica (Wehi 2013a).

Future experiments on expression of weaponry and patterns of development in $\mathrm{H}$. crassidens males could also involve controlled temperature cycles. Minnards et al. (2014) carried out experiments using $H$. crassidens and $H$. thoracica taken from high and low altitude populations that revealed temperature and collection location had a significant effect on growth rate. Controlled breeding studies could investigate the impact of temperature on variation in length of specific instars, growth rate and development of weaponry. Breeding studies in which temperature is controlled could also investigate the potential threshold temperature that may trigger embryo development and hatching in $H$. crassidens.

Future experiments testing the effects of nutrition on tree weta development could focus attention on the selection of plant species in diets given to test subjects. The herbivory only diet treatment presented in this thesis involved only one species of leaf (Coprosma repens), but a natural diet would include a number of species and these leaves vary in their levels of specific nutrients and other components (Griffin, 2011; Dewhurst 2012, Brown 2013). Precise control of the relative amounts of carbohydrates, protein, lipid and nitrogen in the diet would allow further insights into how an individual male's condition affects expression of weaponry. Researchers could also vary the amount of carbohydrates, protein, lipid and nitrogen available in the diet during the earlier and the later instars in order to investigate the potential for catch-up or compensatory growth in tree weta. Much remains to be investigated to better understand the factors affecting the development of male weaponry in 
Hemideina crassidens. Future directions for research could include investigating the heritability of extreme weapon size and condition-dependent expression of weaponry in tree weta. This work could investigate the complex physiological mechanisms underlying the variation observed in this study, particularly the roles of the insulin-like signalling pathway, juvenile hormone and ecdysone (Warren et al. 2013).

Further investigation into the observed differences in head length and body size in males and females from Mana Island and Matiu/Somes Island (Appendix A) may provide insights into how to manage translocations of insect species. The dates and numbers of weta translocated from Mana Island to Matiu/Somes Island is known (Watts et al. 2008) but nothing is known about the characteristics of the individuals that comprised the founder population(s). Recent studies of $H$. crassidens suggest the different male instars may be distinct morphs determined by genetic polymorphism (Nason 2019). Nason (2019) argues that care should be taken to maintain the genetic diversity involved in tree weta translocations in order to maintain the full range of male phenotypes. Carefully controlled rearing studies and paternity analysis are needed to determine the genetic basis of the trimorphism observed in Wellington tree weta (Kelly and Adams 2010). 


\section{References.}

Akaike, H. (1985). Prediction and entropy. In: A. C. Atkinson \& S. E. Fienberg (Eds.), A Celebration of Statistics (pp. 1-24). New York: Springer-Verlag.

Andersson, M. (1986). Evolution of Condition-Dependent Sex Ornaments and Mating Preferences: Sexual Selection Based on Viability Differences. Evolution, 40(4), 804-816.

Barrett P. (1991). Article 1. Keeping the Wellington tree weta, Hemideina crassidens (Blanchard, 1851). In: Keeping weta in captivity (eds GW Ramsey) pp. 10-17. New Zealand: Wellington Zoological Gardens.

Beck, S. D. (1983). Insect thermoperiodism. Annual Review of Entomology, 28(1), 91-108

Berner, D., \& Blanckenhorn, W. U. (2006). Grasshopper ontogeny in relation to time constraints: adaptive divergence and stasis. Journal of Animal Ecology, 75(1), 130-139.

Bradshaw, C. J. A., Mollet, H. F., \& Meekan, M. G. (2007). Inferring population trends

for the world's largest fish from mark-recapture estimates of survival. Journal of Animal Ecology, 76(3), 480-489.

Blanchard, E. (1851). In Gay, C. (Ed.). Fauna chilena. Orden VI. Ortópteros. Historia física y politica de Chile, Museo de historia natural de Santiago. (pp. 5-85) Paris \& Chile 6 (Zool.).

Braendle, C., Heyland, A. and Flatt, T. (2011). Mechanisms of life history evolution the genetics and physiology of life history traits and trade-offs. Oxford: Oxford University Press.

Brown, M. (2013). The Diet and Nutritional Ecology of the Auckland Tree Wētā Hemideina thoracica. MSc, The University of Waikato, Hamilton, New Zealand.

Brown, M. B. G. J., Gemmill, C. E. C., Miller, S., \& Wehi, P. M. (2018). Diet selectivity

in a terrestrial forest invertebrate, the Auckland tree wētā, across three habitat zones. Ecology and Evolution, 8(5), 2495-2503. 
Bulgarella, M., Trewick, S. A., Minards, N. A., Jacobson, M. J., \& Morgan-Richards, M. (2014). Shifting ranges of two tree weta species (Hemideina spp.): competitive exclusion and changing climate. Journal of Biogeography, 41(3), 524-535.

Burmeister, H. (1838). Handbuch der Entomologie 2 2(I-VIII) (p. 718). Accessed from: https://www.biodiversitylibrary.org/item/82123\#page/334/mode/1up

Burnham, K. P., White, G.C., and Anderson, D. R. (1995). Model selection in the analysis of capture-recapture data. Biometrics 51, 888-898.

Cheverud, J. M. (1982). Relationships among ontogenetic, static, and evolutionary allometry. American Journal of Physical Anthropology, 59(2), 139-149.

Chown, S., \& Nicolson, S. (2004). Nutritional physiology and ecology. In: Insect Physiological Ecology: Mechanisms and Patterns (pp. 1-72). Oxford University Press:

Chronis, L. (2009). Matiu/Somes Island environmental education resource (3rd Edition). New Zealand: Department of Conservation.

Clutton-Brock, T. H., \& Huchard, E. (2013). Social competition and selection in males and females. Philosophical transactions of the Royal Society of London. Series B, Biological sciences, 368(1631), 20130074

Coll, M., \& Guershon, M. (2002). Omnivory in Terrestrial Arthropods: Mixing Plant and Prey Diets. Annual Review of Entomology, 47(1), 267-297

Danks, H. V. (2006). Insect adaptations to cold and changing environments. Canadian Entomologist, 138(1), 1-23.

Danks, H. (2007). The elements of seasonal adaptations in insects. Canadian Entomologist, 139(1), 1-44.

Darwin, C.R. (1871). The Descent of Man and Selection in Relation to Sex. New York, Rand McNally.

Dewhurst, R. (2012). The diet of tree wētā: Natural and captive folivory preferences of Hemideina crassidens and Hemideina thoracica. MSc, Massey University, Palmerston North, New Zealand.

Diaz, B., \& Fereres, A. (2005). Life Table and Population Parameters of Nasonovia Ribisnigri (Homoptera: Aphididae) at Different Constant Temperatures. Environmental Entomology, 34(3), 527-534. 
Eberhard, W. G., \& Gutierrez, E. E. (1991). Male Dimorphisms in Beetles and Earwigs and the Question of Developmental Constraints. Evolution, 45(1), 18-28.

Egset C, K., Bolstad G, H., Rosenqvist, G., Endler J, A., \& Pélabon, C. (2011). Geographical variation in allometry in the guppy (Poecilia reticulata). Journal of Evolutionary Biology, 24(12), 2631-2638.

Ehrlich, P. R. \& L. E. Gilbert (1973). Population Structure and Dynamics of the Tropical Butterfly Heliconius ethilla. Biotropica 5(2), 69-82.

Emlen, D. J. (1997). Diet Alters Male Horn Allometry in the Beetle Onthophagus acuminatus (Coleoptera: Scarabaeidae). Proceedings: Biological Sciences 264(1381): 567-574.

Emlen, D. J. (2008). The Evolution of Animal Weapons. Annual Review of Ecology, Evolution, and Systematics, 39(1), 387-413.

Emlen, D. J. \& H. F. Nijhout (2000). The Development and Evolution of Exaggerated Morphologies in Insects. Annual Review of Entomology 45(1): 661.

Emlen, D. J., Marangelo, J., Ball, B., \& Cunningham, C. W. (2005). Diversity in the Weapons of Sexual Selection: Horn Evolution in the Beetle Genus Onthophagus (Coleoptera: Scarabaeidae). Evolution, 59(5), 1060-1084.

Emlen, S. T. \& L. W. Oring (1977). Ecology, sexual selection, and the evolution of mating systems. Science, 197(4300), 215-223.

Esperk, T., Tammaru, T., Nylin, S., \& Teder, T. (2007). Achieving high sexual size dimorphism in insects: females add instars. Ecological Entomology, 32(3), 243-256.

Field, L.H. \& Deans, N.A. (2001) Sexual selection and secondary sexual characters of wetas and king crickets. In: L. H. Field (Ed.) The Biology of Wetas, King Crickets and their Allies (pp. 179-204). Wallingford: CAB International.

Field, L. H. \& Sandlant, G. R. (2001). The gallery-related ecology of New Zealand tree wetas, Hemideina femorata and Hemideina crassidens (Orthoptera, Anostostomatidae). In: L. H. Field (Ed.) The Biology of Wetas, King Crickets and their Allies (pp. 243-257). Wallingford: CAB International.

Fabian, D. \& Flatt, T. (2012 ). Life History Evolution. Nature Education Knowledge, 3(10), 24. 
Gibbs, G. W. (2001). Habitats and biogeography of New Zealand's Deinacridine and tusked weta species. In: The Biology of Wetas, KIng Crickets and their Allies (pp. 35-55). Wallingford: CAB International.

Gould, S. J. (1966). Allometry and size in ontogeny and phylogeny. Biological Reviews, 41(4), 587-638.

Griffin, M. J. (2011). Wellington tree weta (Hemideina crassidens) diet and the effect of some of their dietary choices. MSc, Massey University, Palmerston North, New Zealand.

Griffin, M. J., Morgan-Richards, M., \& Trewick, S. A. (2011). Is the tree wētā Hemideina crassidens an obligate herbivore? . New Zealand Natural Sciences, 36, 11-19.

Griffin, M. J., Holwell, G. I., \& Symonds, M. R. E. (2019). Insect harem polygyny: when is a harem not a harem? Behavioral Ecology and Sociobiology, 73(4), 40.

Gross, M. R. (1996). Alternative reproductive strategies and tactics: diversity within sexes. Trends in Ecology \& Evolution 11(2): 92-98.

Gwynne D.T. \& I.G. Jamieson (1998). Sexual Selection and Sexual Dimorphism in a Harem-Polygynous Insect, the Alpine Weta (Hemideina maori, Orthoptera Stenopelmatidae). Ethology, Ecology and Evolution 10: 393-402.

Hassell, M. P., \& Southwood, T. R. E. (1978). Foraging Strategies of Insects. Annual Review of Ecology and Systematics, 9, 75-98.

Hill, G. E. (2011). Condition-dependent traits as signals of the functionality of vital cellular processes. Ecology Letters, 14(7), 625-634.

lyengar, V. K. and B. D. Starks (2008). Sexual selection in harems: male competition plays a larger role than female choice in an amphipod. Behavioral Ecology 19(3): 642-649.

Jamieson, I. G., M. R. Forbes, et al. (2000). Mark-recapture study of mountain stone weta Hemideina maori (Orthoptera: Anostostomatidae) on rock tor 'islands'. New Zealand Journal of Ecology 24(2): 209-214.

Joyce, S. J., Jamieson, I.G. \& Barker, R.. (2004). "Survival of adult mountain stone weta Hemideina maori (Orthoptera: Anostostomatidae) along an altitude gradient as determined by mark-recapture." New Zealand Journal of Ecology 28(1): 55-61. 
Kelly, C. D. (2005a). Allometry and sexual selection of male weaponry in Wellington tree weta, Hemideina crassidens. Behavioral Ecology 16(1): 145-152.

Kelly, C. D. (2005b). Sexual selection, mating system and ecology of the Wellington tree weta (Hemideina crassidens). PhD, Toronto, University of Toronto.

Kelly, C. D. (2006a). Fighting for harems: assessment strategies during male-male contests in the sexually dimorphic Wellington tree weta. Animal Behaviour, 72(3), 727-736.

Kelly, C. D. (2006b). "Movement patterns and gallery use by the sexually dimorphic Wellington tree weta." New Zealand Journal of Ecology. 30(2): 273-278.

Kelly, C. D. (2006c). "Resource quality or harem size: what influences male tenure at refuge sites in tree weta (Orthoptera: Anostostomatidae)?" Behavioral Ecology and Sociobiology 60(2): 175-183.

Kelly, C. D. (2006d). "The Relationship Between Resource Control, Association with Females and Male Weapon Size in a Male Dominance Insect." Ethology 112(4): 362-369.

Kelly, C. D. (2008a). Identifying a causal agent of sexual selection on weaponry in an insect. Behavioral Ecology 19(1): 184-192.

Kelly, C. D. (2008b). "Why Do Male Tree Weta Aggressively Evict Females from Galleries After Mating?" Ethology 114(2): 203-208.

Kelly, C.D. (2008c). The interrelationships between resource-holding potential, resource-value and reproductive success in territorial males: How much variation can we explain? Behavioral Ecology and Sociobiology 62(6): 855-871.

Kelly, C. D. \& M. D. Jennions (2009). Sexually dimorphic immune response in the harem polygynous Wellington tree weta Hemideina crassidens. Physiological Entomology 34(2): 174-179.

Kelly, C. D., Adams, D.C. (2010). Sexual Selection, Ontogenetic Acceleration, and Hypermorphosis Generates Male Trimorphism in Wellington Tree Weta. Evolutionary Biology, 37(4), 200-209.

Kingsolver, J. G. (2007). Variation in growth and instar number in field and laboratory Manduca sexta. Proceedings. Biological sciences, 274(1612), 977-981.

Kodric-Brown, A., Sibly, R. M., \& Brown, J. H. (2006). The allometry of ornaments and weapons. Proceedings of the National Academy of Sciences, 103(23), 8733-8738. 
Koning, J. W. \& I. G. Jamieson (2001). Variation in size of male weaponry in a harem-defence polygynous insect, the mountain stone weta Hemideina maori (Orthoptera: Anostostomatidae). New Zealand Journal of Zoology 28: 109-117.

Le Gall, M., \& Behmer, S. T. (2014). Effects of Protein and Carbohydrate on an Insect Herbivore: The Vista from a Fitness Landscape. Integrative and Comparative Biology, 54(5), 942-954.

Lavine, L., Gotoh, H., Brent, C., Dworkin, I., Emlen, D.J. (2015). Exaggerated Trait Growth in Insects. Annual Review of Entomology, 60(1), 453-472.

Lebreton, J.-D., Burnham, K. P., Clobert, J., \& Anderson, D. R. (1992). Modeling survival and testing biological hypotheses using marked animals: a unified approach with case studies. Ecological Monographs, 62(1), 67-118.

Leisnham, P. T., \& Jamieson, I. G. (2002). Metapopulation dynamics of a flightless alpine insect Hemideina maori in a naturally fragmented habitat. Ecological Entomology, 27(5), 574-580.

Leisnham, P. T., C. Cameron \& I.G. Jamieson. (2003). Life cycle, survival rates and longevity of an alpine weta Hemideina maori (Orthoptera: Anostostomatidae) determined using mark-recapture analysis. New Zealand Journal of Ecology 27(2): 191-200.

Leisnham P.T. \& I. G. Jamieson (2004). Relationship between male head size and mating opportunity in the harem-defence, polygynous tree weta Hemideina maori (Orthoptera: Anostostomatidae). New Zealand Journal of Ecology 28(1): $49-54$.

Lindenfors P., Tullberg B.S. and M. Biuw (2002). Phylogenetic analyses of sexual selection and sexual size dimorphism in pinnipeds. Behavioral Ecology and Sociobiology 52(3): 188-193.

Lloyd, M. (1967). Mean Crowding. Journal of Animal Ecology 36(1): 1-30.

McCallum, H. (2000). Population Parameters: Estimation for Ecological Models, Blackwell Science Ltd.

McIntyre M.E. 2001. The ecology of some large weta species in New Zealand. In L. $\mathrm{H}$. Field (Ed.) :The Biology of Wetas, King Crickets and their Allies (pp. 225-242). Wallingford: CAB International.

McKean, N. E., Trewick, S. A., Griffin, M. J., Dowle, E. J., \& Morgan-Richards, M. 
(2018). Viability and fertility of hybrid New Zealand tree wētā Hemideina spp. (Orthoptera: Anostostomatidae). Journal of Orthoptera Research, 27(2), 97-106.

Minards, N. A. (2011). Physiological Ecology of Two Tree Weta Species. MSc, Massey University, Palmerston North, New Zealand.

Minards, N. A., Trewick, S. A., Godfrey, A. J. R., \& Morgan-Richards, M. (2014). Convergent local adaptation in size and growth rate but not metabolic rate in a pair of parapatric Orthoptera species. Biological Journal of the Linnean Society, 113(1), 123-135.

Moller, H. (1985). "Tree wetas (Hemideina crassicruris) (Orthoptera: Stenopelmatidae) of Stephens Island, Cook Strait." New Zealand Journal of Zoology 12: 55-69.

Morgan-Richards, M., \& Gibbs, G. W. (2001). A phylogenetic analysis of New Zealand giant and tree weta (Orthoptera : Anostostomatidae : Deinacrida and Hemideina) using morphological and genetic characters. Invertebrate Systematics, 15(1), 1-12.

Nason, S. (2019). The maintenance of alternative strategies in wellington tree weta (Hemideina crassidens): testing the predictions of the genetic polymorphism hypothesis. MSc, Université du Québec à Montréal, Canada.

Nichols, J.D. (2005). Modern Open-population Capture-Recapture Models. In: Amstrup, S.C., McDonald, T.L., and Manly, B.F.J. (Eds.) Handbook of Capture-Recapture Analysis (p.88-124). Princeton: Princeton University Press.

Pollock, K.H. and Alpizar-Jara (2005). Classical Open-Population Capture -Recapture Models. In: Amstrup, S.C., McDonald, T.L., and Manly, B.F.J. (Eds.) Handbook of Capture-Recapture Analysis (pp.36-57). Princeton: Princeton University Press.

Parker, G. A. (1974). "Assessment strategy and the evolution of fighting behaviour." Journal of Theoretical Biology 47(1): 223-243.

Pélabon, C., Bolstad, G.H., Egset, C.K., Cheverud, J.M., Pavlicev, M., Rosenqvist, G. (2013). On the Relationship between Ontogenetic and Static Allometry. The American Naturalist, 181(2), 195-212.

Pielou, E. C. (1977). Mathematical Ecology, John Wiley \& Sons, Inc.

Robbins, M. M. (1999). Male mating patterns in wild multimale mountain gorilla groups. Animal Behaviour 57: 1013-1020. 
Roff, D. (1980). Optimizing development time in a seasonal environment: The 'ups and downs' of clinal variation. Oecologia, 45(2), 202-208.

Roff, D. A. (1986). Predicting Body Size with Life History Models. BioScience, 36(5), 316-323.

Shuster, S. M. and M. J. Wade (1991). Equal mating success among male reproductive strategies in a marine isopod. Nature 350(6319): 608-610.

Shuster, S. M. \& M. J. Wade (2003). Mating Systems and Strategies, Princeton, NJ: Princeton Univ. Press.

Shingleton, A. W. (2010). Allometry: The Study of Biological Scaling. Nature Education Knowledge, 3(10), 2.

Spencer, A. M. (1995). Sexual maturity in the male tree weta Hemideina crassidens (Orthoptera: Stenopelmatidae). MSc, Victoria University of Wellington: New Zealand.

Stearns, S. C. (2000). Life history evolution: successes, limitations, and prospects. Naturwissenschaften, 87(11), 476-486.

Stringer, I. A. N. \& P. R. L. Cary (2001). Postembryonic development and related changes. In: L. H. Field (Ed.) The Biology of Wetas, King Crickets and their Allies (pp. 179-204). Wallingford: CAB International.

Taniguchi, N., \& Tomioka, K. (2003). Duration of development and number of nymphal instars are differentially regulated by photoperiod in the cricket Modicogryllus siamensis (Orthoptera: Gryllidae). European Journal of Entomology 100, 75-281.

Trewick, S. A., \& Morgan-Richards, M. (1995). On the distribution of tree weta in the North Island, New Zealand. Journal of the Royal Society of New Zealand, 25(4), 485-493.

Trewick, S. A., \& Morgan-Richards, M. (2000). Artificial weta roosts: A technique for ecological study and population monitoring of Tree Weta (Hemideina) and other invertebrates. New Zealand Journal of Ecology, 24(2), 201-208.

Truman JW. (2006). Juvenile hormone is required to couple imaginal disc formation with nutrition in insects. Science 312, 1385-8.

van Heugten, R. (2015). Weta affairs : an investigation into the population structure and possible hybridisation of two tree weta species (hemideina) in Canterbury. $P h D$ Thesis, University of Canterbury: New Zealand. 
Wade, M. J. (1995). The ecology of sexual selection: Mean crowding of females and resource-defence polygyny. Evolutionary Ecology 9(1): 118-124.

Wade, M. J. and S. M. Shuster (2004). Sexual Selection: Harem Size and the Variance in Male Reproductive Success. The American Naturalist 164(4): E83-E89.

Walker, F. (1869). Catalogue of the specimens of Dermaptera Saltatoria and supplement to the Blattariae in the collection of the British Museum Part 2. British Museum: London, UK.

Warton D.I., Duursma R.A., Falster D.S. \& Taskinen, S. (2011). smatr 3- an R package for estimation and inference about allometric lines. Methods in Ecology and Evolution, 3(2), 257-259.

Warren I. A., Gotoh, H., Dworkin I.M., Emlen D.J., \& Lavine L.C. (2013). A general mechanism for conditional expression of exaggerated sexually-selected traits. BioEssays, 35(10), 889-899.

Watts, C., I. Stringer, Greg, S., Gibbs, G. \& Green, C. (2008). History of weta (Orthoptera: Anostostomatidae) translocation in New Zealand: lessons learned, islands as sanctuaries and the future. Journal of Insect Conservation 12(3): 359-370.

Wehi, P. M., Jorgensen, M. \& Morgan-Richards, M. (2013a). Sex- and season-dependent behaviour in a flightless insect, the Auckland tree weta (Hemideina thoracica). New Zealand Journal of Ecology, 37(1), 75-83.

Wehi, P. M., Raubenheimer, D. and Morgan-Richards, M. (2013b). Tolerance for Nutrient Imbalance in an Intermittently Feeding Herbivorous Cricket, the Wellington Tree Weta. PLOS ONE, 8(12), 1-11.

Wehi, P. M., Monks, A., \& Morgan-Richards, M. (2017). Male tree weta are attracted to cuticular scent cues but do not discriminate according to sex or among two closely related species. Ethology, 123(11), 825-834.

Wey, T. W., \& Kelly, C. D. (2018). Refuge size variation and potential for sperm competition in Wellington tree weta. Current Zoology, 65(3), 213-223.

White, G., \& Burnham, K. (1999). Program MARK: Survival Estimation from Populations of Marked Animals. Bird Study, 46(Supplement), 120-138.

Whitman, D. W. (2008). The significance of body size in the Orthoptera: a review. Journal of Orthoptera Research 17(2): 117-134.

Wilson, C. G., \& Jamieson, I. G. (2005). Does melanism influence the diet of the 
mountain stone wētā Hemideina maori (Orthoptera: Anostostomatidae)? New Zealand Journal of Ecology, 29, 149-152.

Wilson, A. D. M., \& Kelly, C. D. (2019). Do alternative reproductive strategies in the Wellington tree weta represent different behavioural types? Ethology, 125(6), 380-391.

Yuen, K. K. (1974). "The Two-Sample Trimmed t for Unequal Population Variances." Biometrika 61(1): 165-170.

Zalucki, M.P. and R.L. Kitching. (1984). The dynamics of adult Danaus plexippus L. (Danaidae) within patches of its food plant, Asclepias spp. Journal of the Lepidopterists' Society, 38, 209219.

Zera, A. J., \& Harshman, L. G. (2001). The Physiology of Life History Trade-Offs in Animals. Annual Review of Ecology and Systematics, 32(1), 95-126. 


\section{Appendices.}

Appendix A: Statistics from major axis regression of log head length on log femur length for males (above) and females (below) from all areas surveyed on Matiu/Somes (M/S) Island and from Mana Island, years separate. Maud Island measurements from Kelly (2005a) included for comparison.

\begin{tabular}{|c|c|c|c|c|c|c|c|c|}
\hline Zone & Year & Sex & $n$ & Slope & Intercept & $\begin{array}{l}\text { Lower } \\
\text { CL }\end{array}$ & Upper CL & $r^{2}$ \\
\hline East $\mathrm{M} / \mathrm{S}$ & 2000 & male & 27 & 2.86 & -5.31 & 1.91 & 5.21 & 0.44 \\
\hline East M/S & 2001 & male & 421 & 1.87 & -2.56 & 1.77 & 1.98 & 0.77 \\
\hline East M/S & 2002 & male & 170 & 1.88 & -2.61 & 1.73 & 2.06 & 0.75 \\
\hline East M/S & 2003 & male & 29 & 1.69 & -2.06 & 1.36 & 2.14 & 0.76 \\
\hline East M/S & 2004 & male & 40 & 2.04 & -3.06 & 1.69 & 2.51 & 0.74 \\
\hline East M/S & 2005 & male & 17 & 2.22 & -3.53 & 1.91 & 2.61 & 0.93 \\
\hline East M/S & 2006 & male & 16 & 2.49 & -4.34 & 1.96 & 3.34 & 0.83 \\
\hline West M/S & 2003 & male & 25 & 1.87 & -2.56 & 1.49 & 2.42 & 0.76 \\
\hline West M/S & 2004 & male & 112 & 2.03 & -3.01 & 1.90 & 2.17 & 0.89 \\
\hline West M/S & 2005 & male & 42 & 2.20 & -3.51 & 1.89 & 2.61 & 0.80 \\
\hline South M/S & 2005 & male & 36 & 2.49 & -4.31 & 2.17 & 2.91 & 0.85 \\
\hline South M/S & 2006 & male & 127 & 2.37 & -4.00 & 2.20 & 2.56 & 0.84 \\
\hline South M/S & 2007 & male & 26 & 3.17 & -6.18 & 2.31 & 4.90 & 0.58 \\
\hline Mana Island & 2002 & male & 77 & 2.26 & -3.69 & 2.06 & 2.49 & 0.85 \\
\hline Mana Island & 2003 & male & 23 & 1.99 & -2.90 & 1.61 & 2.54 & 0.80 \\
\hline Maud Island* & 2001 & male & 59 & 2.47 & -1.82 & 2.21 & 2.78 & 0.84 \\
\hline Maud Island* & 2002 & male & 141 & 2.43 & -1.76 & 2.30 & 2.58 & 0.89 \\
\hline Maud Island* & 2003 & male & 357 & 2.44 & -1.78 & 2.36 & 2.54 & 0.89 \\
\hline East $\mathrm{M} / \mathrm{S}$ & 2000 & female & 30 & 1.00 & -0.54 & 0.66 & 1.53 & 0.47 \\
\hline East M/S & 2001 & female & 313 & 1.15 & -0.95 & 1.05 & 1.26 & 0.61 \\
\hline East M/S & 2002 & female & 103 & 1.02 & -0.58 & 0.90 & 1.15 & 0.72 \\
\hline South M/S & 2007 & female & 74 & 1.00 & -0.46 & 0.81 & 1.23 & 0.57 \\
\hline Mana Island & 2002 & female & 100 & 1.32 & -1.48 & 1.06 & 1.65 & 0.46 \\
\hline Maud Island* & 2001 & female & 49 & 1.21 & -0.47 & 0.92 & 1.60 & 0.54 \\
\hline Maud Island* & 2002 & female & 174 & 1.08 & -0.30 & 0.94 & 1.22 & 0.67 \\
\hline Maud Island* & 2003 & female & 381 & 1.09 & -0.32 & 1.00 & 1.17 & 0.63 \\
\hline
\end{tabular}

Data from Matiu/Somes Island collected 2000-2006 by G.W. Gibbs and A.S Dixson

Data from Mana Island collected 2002-2003 by G.W. Gibbs

*Maud Island data from Kelly (2005a). 

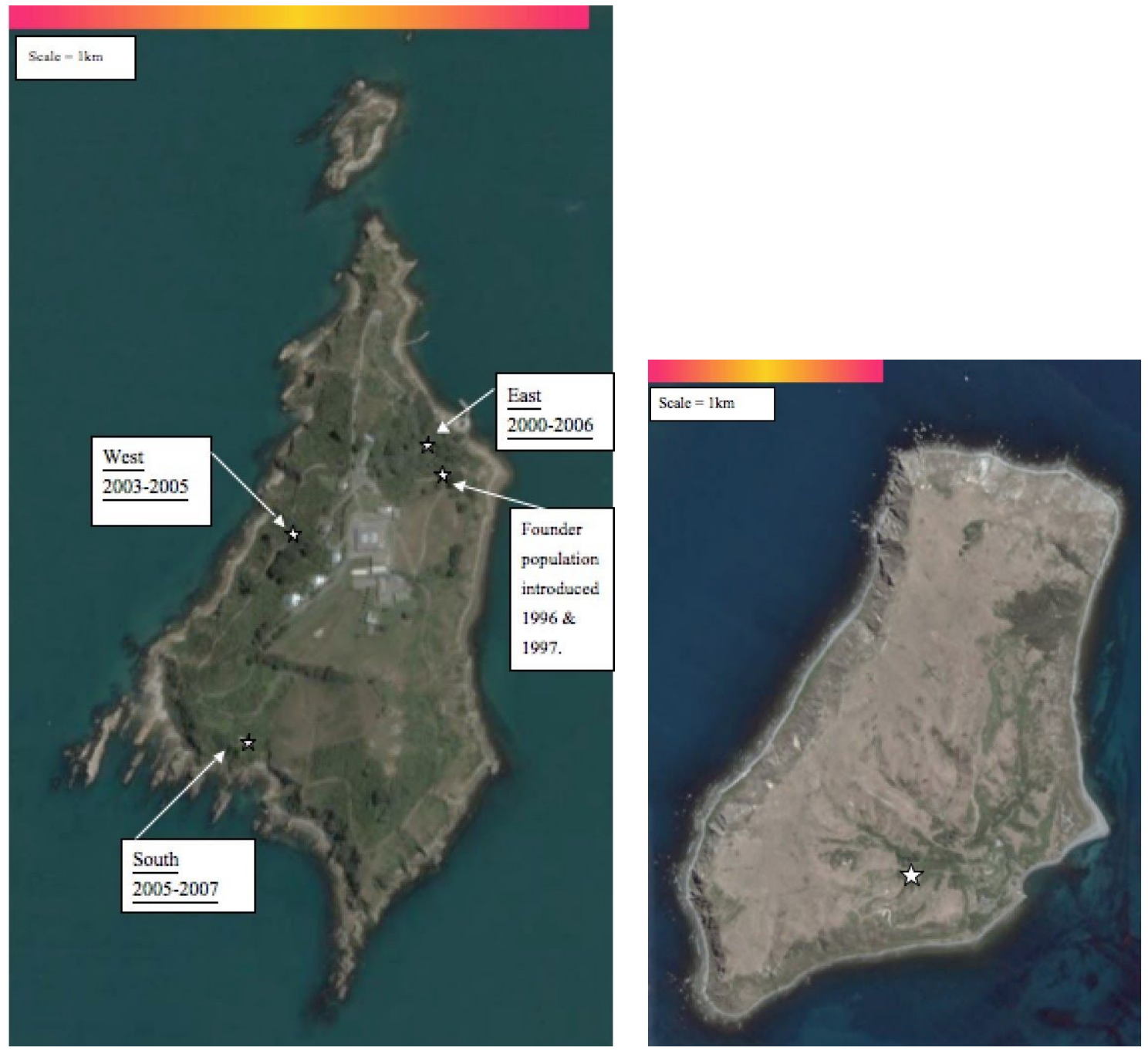

Areas and collection years on Matiu/Somes Island (left) and Mana Island (right) for measurements given in the appendix $B$ table. Maps accessed from:

https://www.google.com/earth/ circa 2009 and annotated by A.S. Dixson. 
Appendix B: Seasons and mean monthly temperatures on Matiu/Somes Island, data used in thesis.

Data from NIWA New Zealand national climate database; Matiu/Somes Island weather recording station 1971 - 2000.

http://cliflo.niwa.co.nz/pls/niwp/doc/terms.html

\begin{tabular}{|c|c|c|c|c|c|}
\hline Season & Month & $\begin{array}{c}\text { Mean Temp } \\
\left({ }^{\circ} \mathbf{C}\right)\end{array}$ & $\begin{array}{c}\text { Mean Daily } \\
\text { Minimum Air } \\
\text { Temperature }\end{array}$ & $\begin{array}{c}\text { Mean Daily } \\
\text { Maximum Air } \\
\text { Temperature }\end{array}$ & $\begin{array}{c}\text { Mean Rainfall } \\
(\mathbf{m m})\end{array}$ \\
\hline \multirow{3}{*}{ SUMMER } & \multirow{2}{*}{$\begin{array}{c}\text { Jecember } \\
\text { January }\end{array}$} & 15.6 & 12.8 & 18.4 & 99.3 \\
\cline { 3 - 6 } & February & 17.1 & 14.2 & 20.2 & 62.8 \\
\cline { 3 - 6 } AUTUMN & March & 17.3 & 14.2 & 20.6 & 63.6 \\
\cline { 3 - 6 } & April & 16.2 & 13.1 & 19.1 & 85 \\
\cline { 3 - 6 } & May & 11.6 & 11.2 & 16.9 & 83.5 \\
\hline \multirow{3}{*}{ WINTER } & June & 9.6 & 9.1 & 14.5 & 104.6 \\
\cline { 3 - 6 } & July & 8.8 & 6.4 & 12.3 & 133.4 \\
\cline { 3 - 6 } & August & 9.4 & 6.8 & 11.7 & 116.4 \\
\hline \multirow{3}{*}{ SPRING } & September & 10.9 & 8.1 & 12.1 & 108.9 \\
\cline { 3 - 6 } & October & 12.2 & 9.4 & 15 & 83.9 \\
\cline { 3 - 6 } & November & 13.6 & 10.7 & 16.5 & 88.4 \\
\hline
\end{tabular}


Appendix C: Guidelines for classifying male Hemideina crassidens to instar, from Spencer (1995 pp. 17-18).

Size categories for $8^{\text {th }}, 9^{\text {th }}$ and $10^{\text {th }}$ instar males, based on Spencer 1995.

\begin{tabular}{|c|c|}
\hline Adult male instar & Head length range $(\mathrm{mm})$ \\
\hline $8^{\text {th }}$ & $>10.09$ and $<13.45$ \\
\hline $9^{\text {th }}$ & $>13.44$ and $<19.25$ \\
\hline $10^{\text {th }}$ & $>19.24$ \\
\hline
\end{tabular}

if weight $<0.63 \mathrm{~g}$

and head length $<10.10 \mathrm{~mm}$

and femur $<8.55 \mathrm{~mm}$

then Prob. $=0.92$ instar is five or below, Freq $=12$ Instar 511

Instar 61

Instar 70

Instar 80

Instar 90

Instar 10: 0

if weight $<0.63 \mathrm{~g}$

and head length $<10.10 \mathrm{~mm}$

and femur $>8.54 \mathrm{~mm}$

then Prob. $=1.00$ instar is six, Freq $=7$ Instar 50

Instar 67

Instar 70

Instar 80

Instar 90

Instar 10: 0

if weight is $>0.62 \mathrm{~g}$

and head length $<10.10 \mathrm{~mm}$

then Prob. $=0.82$ instar is seven, Freq $=28$ Instar 50

Instar 63

Instar 723

Instar 82

Instar 90

Instar 10: 0 
if head length is $>10.09 \mathrm{~mm}$ and $<13.45 \mathrm{~mm}$ then Prob. $=0.98$ instar is eight, Freq $=44$

Instar 50

Instar 60

Instar 70

Instar 843

Instar 91

Instar 10: 0

if head length $>13.44 \mathrm{~mm}$ and $<19.25 \mathrm{~mm}$ then Prob. $=0.97$ instar is nine, Freq $=79$ Instar 50

Instar 60

Instar 70

Instar 81

Instar 977

Instar 10: 1

if head length $>19.24 \mathrm{~mm}$

then Prob $=0.98$ instar is ten, Freq $=48$ Instar 50

Instar 60

Instar 70

Instar 80

Instar 91

Instar $10: 47$ 